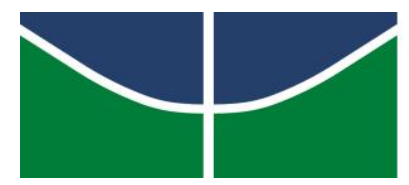

UNIVERSIDADE DE BRASÍLIA (UNB)

FACULDADE DE ECONOMIA, ADMINISTRAÇÃO E CONTABILIDADE (FACE) MESTRADO PROFISSIONAL EM ADMINISTRAÇÃO PÚBLICA (PPGA)

MARCELLE BARROS DOS SANTOS

ANÁLISE DA PARTICIPAÇÃO SOCIAL NA FORMULAÇÃO DAS POLÍTICAS DE EDUCAÇÃO DE NÍVEL SUPERIOR NO PLANO NACIONAL DE EDUCAÇÃO II 
MARCELLE BARROS DOS SANTOS

\section{ANÁLISE DA PARTICIPAÇÃO SOCIAL NA FORMULAÇÃO DAS POLÍTICAS DE EDUCAÇÃO DE NÍVEL SUPERIOR NO PLANO NACIONAL DE EDUCAÇÃO II}

Dissertação submetida ao Programa de Pós-Graduação em Administração da Universidade de Brasília, Mestrado Profissionalizante em Administração Pública, linha de pesquisa Gestão de Políticas Públicas, como requisito parcial para a obtenção do grau de Mestre em Administração.

Prof $^{\mathrm{a}}$. Dra ${ }^{\mathrm{a}}$. Suylan de Almeida Midlej e Silva

\section{Brasília-DF}




\title{
ANÁLISE DA PARTICIPAÇÃO SOCIAL NA FORMULAÇÃO DAS POLÍTICAS DE EDUCAÇÃO DE NÍVEL SUPERIOR NO PLANO NACIONAL DE EDUCAÇÃO II
}

\begin{abstract}
Dissertação submetida ao Programa de Pós-Graduação em Administração da Universidade de Brasília, Mestrado Profissionalizante em Administração Pública, linha de pesquisa Gestão de Políticas Públicas, como requisito parcial para a obtenção do grau de Mestre em Administração.
\end{abstract}

Aprovada em 4 de dezembro de 2015.
Professora Doutora Suylan de Almeida Midlej e Silva
Programa de Pós-Graduação em Administração
Universidade de Brasília
Orientadora

\author{
Professor Doutor João Mendes Rocha Neto \\ Programa de Pós-Graduação em Administração \\ Universidade de Brasília \\ Examinador Interno
}
Professora Doutora Catarina de Almeida Santos
Programa de Pós-Graduação em Educação
Universidade de Brasília
Examinador Externo

Professor Doutor Adalmir de Oliveira Gomes

Programa de Pós-Graduação em Administração

Universidade de Brasília

Suplente 


\section{AGRADECIMENTOS}

A meu esposo e companheiro, Alisson Neres Lindoso, por toda a ajuda que me deu. E, sobretudo, pelas horas que passou ao meu lado me orientando, esclarecendo dúvidas e solucionando problemas. E ainda por sua generosidade e inteligência que me cativam a cada dia e me incentivam a melhorar como ser humano. O seu envolvimento nas coisas que faço é tremendamente importante para me manter motivada e, por que não, feliz!?!?

Agradeço a minha mãe, Maria do Socorro Barros dos Santos, e meu pai, José Reinaldo Vieira dos Santos, pelo carinho, apoio e incentivo que a mim deram ao longo dessa jornada. Agradeço também a minha irmã, Mayana Barros dos Santos, pela compreensão e pelas conversas em momentos de tensão.

À CGPES/FNDE pela ajuda prestada nos momentos em que precisei. Pela compreensão e incentivo que me deram nesses dois anos e pelo aprendizado que obtive nesse tempo. Aos sujeitos sociais participantes dessa pesquisa que se dispuseram a dialogar sobre suas vivências e ajudaram-me nesse estudo.

À banca examinadora do projeto da dissertação, pelas valiosas observações e sugestões. Em especial à Professora Orientadora Suylan Midlej pelo acompanhamento, dedicação e contribuições à concretização deste estudo.

Agradeço aos colegas que conheci no Programa de Pós-Graduação em Administração. Certamente, os questionamentos levantados em sala e as discussões travadas sobre os temas mais diversos me fizeram refletir sobre as minhas próprias opiniões e com isso evoluir como profissional. Tenham toda a certeza de que a minha formação não seria completa se não fosse pelo coleguismo e pela ajuda de alguns de vocês nos trabalhos que realizamos juntos. 
RESUMO

O objetivo desta pesquisa foi analisar em que medida houve participação social na formulação do atual Plano Nacional de Educação II (PNE 2014 -2024) em relação à construção das metas para a educação de nível superior. Para tanto, foi discutida a definição de movimentos sociais e participação social e debatida a relação entre Estado e sociedade, sobretudo no contexto da educação no Brasil. Em seguida, procurou-se realizar um estudo sobre os múltiplos fluxos de Kingdom para definir se houve influência no contexto das discussões do Projeto de Lei $\mathrm{n}^{\circ}$ 8.035/2010. A pesquisa foi exploratória e descritiva baseada no método qualitativo, usando-se de análise documental e entrevistas semiestruturadas cujas categorias objetivavam discutir a atuação da sociedade civil por meio da Conferência Nacional de Educação 2010 na formulação de políticas de educação de nível superior. Os resultados apontam que a atuação da Conae se caracteriza como espaço de participação social em que se definem diretrizes e ações que nortearão as políticas de educação de nível superior, contudo, a implementação dessas políticas, principalmente, no que se refere à destinação de recursos públicos exclusivamente para a educação pública, ainda não tem sido realizada em sua integridade.

Palavras-chave: Participação social. Plano Nacional de Educação II. Educação de Nível Superior 


\begin{abstract}
The objective of this research is to analyze to what extent there was social participation in the formulation of the current National Education Plan II (PNE 2014 - 2024) regarding the construction of the goals for higher education. Therefore, we used the theoretical framework that addresses the definition of social movements and social participation, the relationship between state and society, particularly in the context of education in Brazil. Afterward, a research about the multiple streams of Kingdom has been done to determine whether there was influence on Bill No. 8035/2010. The research was exploratory and descriptive based on qualitative method, using document analysis and semi-structured individual interviews whose categories aimed to discuss the role of civil society through the National Conference on Education in 2010 in the formulation of higher education policies. The results show that the performance of CONAE is characterized as a space for social participation which defines guidelines and actions that will guide the higher education policies, however, the implementation of these policies, especially with regard to the allocation of public funds exclusively for public education, it has not been performed in its entirety.
\end{abstract}

Keywords: Social Participation. National Education Plan II. Higher Education. 


\section{LISTA DE QUADROS}

Quadro 1: Comparativo entre versões do PNE II (Lei 13.005/2014) .......................................22

Quadro 2:Entrevistados Bloco A - Representantes da sociedade civil ..................................58

Quadro 3: Entrevistados Bloco B - Representantes do governo...........................................59

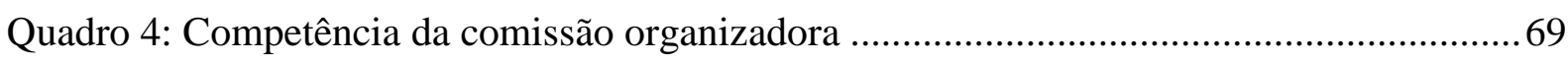

Quadro 5: Composição dos atores na etapa estadual........................................................... 75 


\section{LISTA DE TABELAS}

Tabela 1: Evolução do Número de Instituições, segundo a Categoria

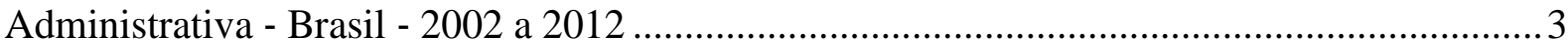

Tabela 2: Participação de acordo com a temática da conferência .......................................... 31

Tabela 3: Conferência em que participou mais ativamente ....................................................... 32 


\section{LISTA DE ABREVIAÇÕES E SIGLAS}

ABI

ABRUC

ANDE

ANDES -

SN

ANDIFES

ANFOPE

ANPAE

ANPED

CNBB

CNTE

CONAE

CONCEFET Conselho de Dirigentes dos Centros Federais de Educação Tecnológica

CONFENEN Confederação Nacional de Estabelecimentos de Ensino

CONED Congressos Nacionais de Educação

CONSED Conselho Nacional de Secretários de Educação

CONTEE Confederação Nacional dos Trabalhadores em Estabelecimentos de Ensino

CRUB Conselho de Reitores das Universidades Brasileiras

CUT

DEM

Fasubra

INEP

MST

OAB

PCdoB

\section{Central Única dos Trabalhadores}

Democratas

Federação de Sindicatos de Trabalhadores das Universidades Brasileiras Instituto Nacional de Estudos e Pesquisas Educacionais Anísio Teixeira Movimento dos Trabalhadores Sem-Terra

Ordem dos Advogados do Brasil

Partido Comunista do Brasil 


\begin{tabular}{ll} 
PDE & Plano de Desenvolvimento da Educação \\
PDT & Partido Democrático Trabalhista \\
PFL & Partido da Frente Liberal \\
PLC & Partido Liberal Cristão \\
PMDB & Partido do Movimento Democrático Brasileiro \\
PNE & Plano Nacional de Educação \\
PP & Partido Progressista \\
PPS & Partido Popular Socialista \\
PR & Partido da República \\
PRB & Partido Republicano Brasileiro \\
PSB & Partido Socialista Brasileiro \\
PSC & Partido Social Cristão \\
PSDB & Partido da Social Democracia Brasileira \\
PSOL & Partido Socialismo e Liberadade \\
PTB & Partido Trabalhista Brasileiro \\
PV & Partido Verde \\
UNAE & Secretaria de Articulação com os Sistemas de Ensino \\
UBES & União Brasileira de Estudantes Secundaristas \\
Undime & União Nacional dos Dirigentes Municipais de Educação \\
\hline & Unacional dos Estudantes \\
\hline &
\end{tabular}




\section{SUMÁRIO}

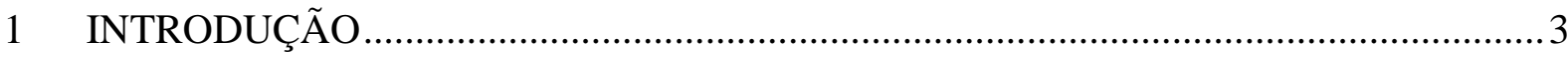

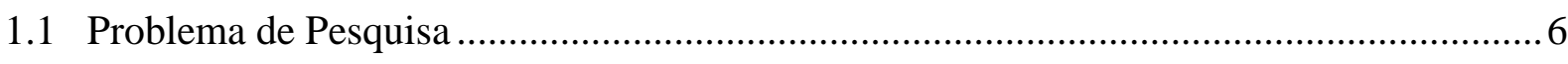

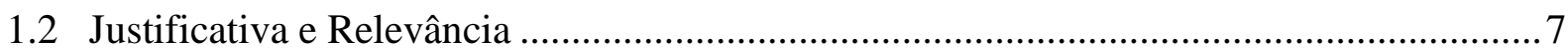

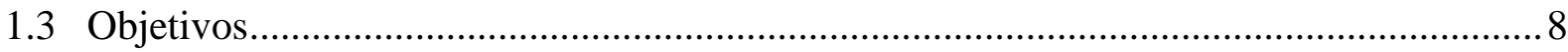

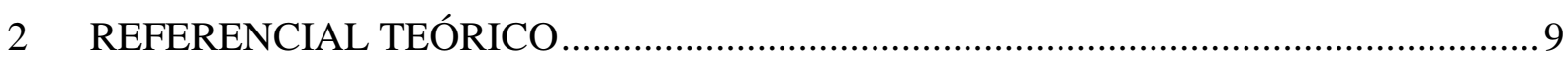

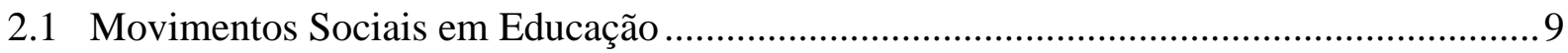

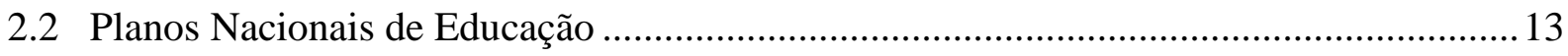

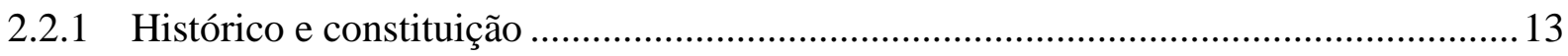

2.2.2 Planos Nacionais de Educação pós Constituição Federal de 1988.............................. 16

2.2.3 Planos Nacionais de Educação e Movimentos Sociais............................................... 24

2.3 Formulação de políticas públicas e os PNEs …............................................................ 33

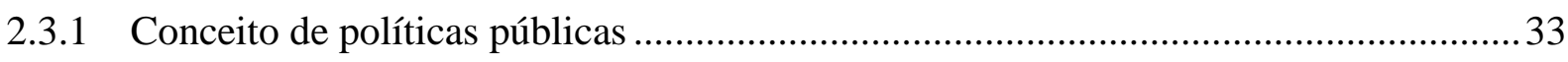

2.3.2 Formulação de Políticas Públicas .......................................................................... 38

2.3.3 Sociedade Civil e Políticas Públicas ................................................................................ 41

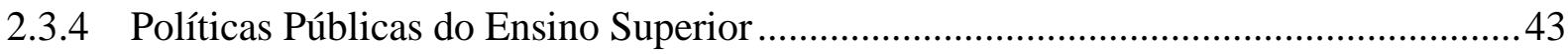

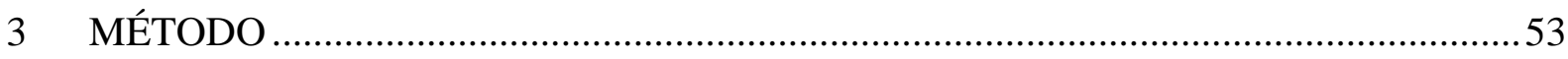

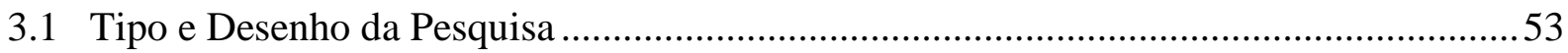

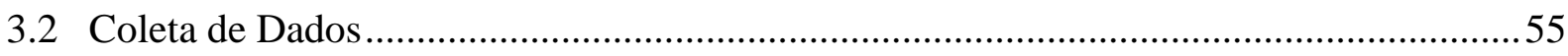

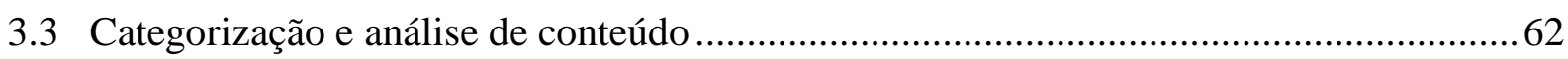

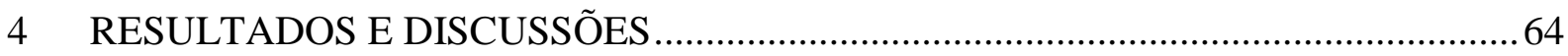

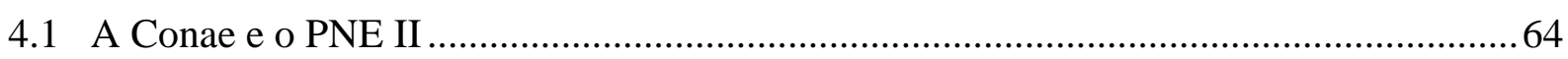

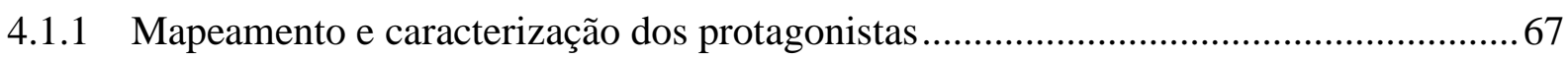

4.1.1.1 Composição da Conae e competências de seus membros .....................................67

4.1.1.2 Organização e metodologia da Conae ................................................................. 73

4.1.2 Influência da participação social na elaboração do PNE II ...........................................77 
4.1.2.1 Contribuições das conferências na formulação de políticas de educação de nível superior 77

4.1.2.2 Aumento da influência da Conae na formulação de políticas de educação de nível superior 84

4.1.3 Relação entre Estado e sociedade civil no âmbito da Conae 87

4.1.3.1 Dinâmica entre governo e sociedade civil........................................................... 87

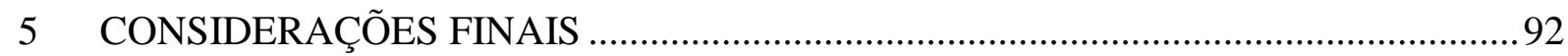

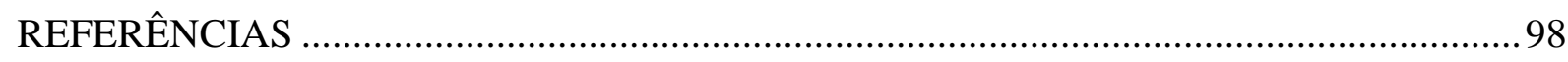

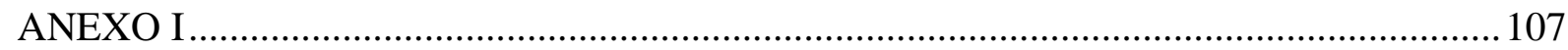




\section{INTRODUÇÃO}

A educação superior brasileira caracterizou-se na última década pela forte expansão do ensino superior privado (BRANDÃO, 2006). Segundo o Censo de Educação Superior de 2012, o número de instituições públicas em 2002 era de 195, distribuídas da seguinte forma: 73 eram federais, 65 estaduais e 57 municipais. Enquanto que a rede privada era composta por 1442 instituições. Essa categoria atinge 2016 instituições em 2012. Já no cenário de instituições públicas, percebe-se o aumento para 236 instituições (INSTITUTO NACIONAL DE ESTUDOS E PESQUISAS EDUCACIONAIS ANÍSIO TEXEIRA, 2012), conforme tabela 1 abaixo:

Tabela 1: Evolução do Número de Instituições, segundo a Categoria Administrativa Brasil 2002 a 2012

\begin{tabular}{|c|c|c|c|c|c|c|c|c|c|c|c|c|}
\hline \multirow[b]{2}{*}{ Ano } & \multirow[b]{2}{*}{ Total } & \multirow[b]{2}{*}{$\% \Delta$} & \multicolumn{8}{|c|}{ Pública } & \multirow[b]{2}{*}{ Privada } & \multirow[b]{2}{*}{$\% \Delta$} \\
\hline & & & Total & $\% \Delta$ & Federal & $\% \Delta$ & Estadual & $\% \Delta$ & Municipal & $\% \Delta$ & & \\
\hline 2002 & 1.637 & - & 195 & - & 73 & - & 65 & _- & 57 & - & 1.442 & - \\
\hline 2003 & 1.859 & 13,6 & 207 & 6,2 & 83 & 13,7 & 65 & 0 & 59 & 3,5 & 1.652 & 14,6 \\
\hline 2004 & 2.013 & 8,3 & 224 & 8,2 & 87 & 4,8 & 75 & 15,4 & 62 & 5,1 & 1.789 & 8,3 \\
\hline 2005 & 2.165 & 7,6 & 231 & 3,1 & 97 & 11,5 & 75 & 0 & 59 & $-4,8$ & 1.934 & 8,1 \\
\hline 2006 & 2.270 & 4,8 & 248 & 7,4 & 105 & 8,2 & 83 & 10,7 & 60 & 1,7 & 2.022 & 4,6 \\
\hline 2007 & 2.281 & 0,5 & 249 & 0,4 & 106 & 1 & 82 & $-1,2$ & 61 & 1,7 & 2.032 & 0,5 \\
\hline 2008 & 2.252 & $-1,3$ & 236 & $-5,2$ & 93 & $-12,3$ & 82 & 0 & 61 & 0 & 2.016 & $-0,8$ \\
\hline 2009 & 2.314 & 2,8 & 245 & 3,8 & 94 & 1,1 & 84 & 2,4 & 67 & 9,8 & 2.069 & 2,6 \\
\hline 2010 & 2.378 & 2,8 & 278 & 13,5 & 99 & 5,3 & 108 & 28,6 & 71 & 6,0 & 2.100 & 1,5 \\
\hline 2011 & 2.365 & $-0,5$ & 284 & 2,2 & 103 & 4,0 & 110 & 1,9 & 71 & 0,0 & 2.081 & $-0,9$ \\
\hline 2012 & 2416 & 2,2 & 304 & 7,0 & 103 & 0,0 & 116 & 5,5 & 85 & 19,7 & 2112 & 1,5 \\
\hline
\end{tabular}

Fonte: MEC/INEP/DEED, 2012

Diante desse quadro, o desafio que se apresenta para a educação superior é aumentar o número de vagas nas instituições de ensino superior públicas e, sobretudo, imprimir qualidade na prestação desse serviço (BRANDÃO, 2006; SGUISSARDI, 2007). Baseado nisso, as discussões envolvendo esse cenário se ampliaram quando da elaboração dos Planos Nacionais de Educação nos Fóruns Nacionais de Educação, resultado das Conferências Nacionais de Educação - Conae. Com isso, torna-se relevante contextualizar os movimentos sociais protagonistas que participaram do processo de construção e aprovação do atual Plano Nacional de Educação, seus atores e formas de funcionamento.

Os movimentos sociais no Brasil intensificaram-se na década de 1970, quando as organizações sociais lutavam pela ampliação dos direitos políticos e sociais e por novas formas de políticas econômicas que viabilizassem geração de emprego e melhor distribuição de renda. Esses movimentos tiveram importante papel na redefinição de formas de espaços de participação e na construção de políticas sociais junto ao Estado (CARDOSO, 1994). 
A década de 1980 foi marcada pela reordenação dos movimentos sociais conhecida também como a institucionalização dos movimentos. Para tanto, houve a constituição de partidos políticos, a mobilização de movimentos sociais bem como a abertura de canais de negociação com o Estado. Esse processo se consolidou com a promulgação de Constituição de 1988 (CARDOSO, 1994).

A partir da década de 1990, os movimentos redirecionaram suas ações para a participação na formulação de políticas, a fim de construir e negociar direitos tanto no que diz respeito aos direitos oficiais estatais como também para tratar daqueles que ampliassem a participação de diversos movimentos sociais institucionalizados ou não. A partir de então, tem-se que diversas práticas democráticas, sobretudo no governo Lula, vêm sendo institucionalizadas (AVRITZER, 2009).

A consolidação da participação social nas últimas décadas efetivou-se principalmente por meio de mecanismos de ação social como plebiscito e referendo - que são instrumentos mais tradicionais -, conselhos, audiências públicas e também com novas práticas como as conferências de políticas públicas. Observa-se que a ampliação da participação dos cidadãos com essas novas práticas democráticas não invalida os instrumentos mais antigos como o sufrágio. Ao contrário, serve para fortalecer a democracia representativa (BRASIL, 2009).

Segundo Avritzer (2012), dentro dessas novas práticas, as conferências nacionais tornaram-se importantes meios para ampliar a participação social no ciclo de políticas públicas. Desde 2003, o governo federal vem adotando uma orientação mais participativa, o que expande as conferências nacionais. Essa mudança de cenário proporciona novas formas de se fazer política. Isso porque traz para a arena de decisão atores que impulsionam o diálogo nas diversas esferas de poder, sobretudo no legislativo.

Com essa nova dinâmica de funcionamento dos institutos de participação é necessário analisar conceitos da teoria democrática deliberativa. Com isso, pretende-se trazer a tona formas de democracia participativa que se articulem com a democracia representativa a fim de diminuir a distância entre a elite política e burocrática e os cidadãos. Nesse contexto, onde se inseririam as discussões envolvendo os movimentos sociais e a educação?

As lutas e movimentos pela educação têm caráter histórico e ocorrem tanto nas escolas como em outros espaços institucionais. Nas décadas de 1960 e 1970, a relação entre movimentos sociais e educação se dava no âmbito de discussões sobre utilização de métodos de ensino e sobre a conscientização do indivíduo enquanto ser social ativo e participante de seu processo de aprendizagem, como argumentou Paulo Freire, e sobre a relação entre 
educação escolar do ensino superior e os movimentos sociais. Em 1980 essa relação se acentua, por meio de trabalhos de educação popular, lutas pelas Diretas Já e organização de propostas para a Constituinte. Em contrapartida, nos anos de 1990, houve, de forma geral, a desmobilização de movimentos sociais e novas políticas públicas passaram a pautar assuntos de cidadania e participação. No âmbito da educação foi aprovada a Lei de Diretrizes e Bases (LDB), a partir de um processo de mobilização. Nesse novo momento, há inúmeras propostas e ações, pois há propostas articuladas e fundadas em projetos sociopolíticos e culturais emancipatórios, mas também propostas que buscam articular coesão social (GOHN, 2012).

No espectro de reivindicações e demandas dos movimentos sociais pela educação no ensino superior, é possível elencar algumas: contratação de professores, mais verbas para a educação, expansão e acesso ao ensino universitário e cotas para os socioeconomicamente excluídos (GOHN, 2012). Esta pesquisa pretende compreender se essas demandas apresentadas nas instâncias de participação social influenciaram a formulação do Plano Nacional de Educação 2014 - 2024.

Sob a ótica das ciências jurídicas, observa-se que o princípio democrático, do qual emerge a ideia de cidadania social, se apresenta em vários normativos da Carta Magna de 1988. Ele está explicitado, por exemplo, no artigo $1^{\circ}$ da constituição brasileira de 1988 quando afirma que a República Federativa do Brasil define-se como um Estado Democrático de Direito. A partir deste princípio, a democracia "implica a estruturação de processos que ofereçam aos cidadãos efetivas possibilidades de aprender a democracia, participar nos processos de decisão, exercer o controle crítico na divergência de opiniões, produzir inputs políticos democráticos" (Canutilho apud Perez, 2009, p. 73), influenciando, portanto, a forma como se apresenta a administração pública.

O outro princípio mencionado no artigo $1^{\circ}$ diz respeito ao Estado de Direito. A partir dele, o Estado se vê com o dever de promover os direitos fundamentais, o que implica a admissão de instrumentos que permitem às organizações estatais atingirem o objetivo de colaboração com a sociedade. Estes princípios, segundo Perez (2009), impõem uma forma de organização das funções do Estado que seja voltada à plena realização da democracia participativa e dos objetivos do Estado de Direito material e efetivação dos direitos fundamentais.

Apesar destes princípios respaldarem a participação social na administração pública brasileira, a Constituição de 1988 apresenta normativos que tratam desses institutos, como é o caso do artigo 10, que determina a participação dos trabalhadores e empregados nos colegiados dos órgãos públicos ou ainda no seu artigo 29, XII, que versa sobre cooperação das 
associações representativas no planejamento municipal. Trazendo a discussão para o âmbito da pasta da educação, a Constituição Federal prevê em seu artigo 205 que a educação será promovida e incentivada com a colaboração da sociedade.

A Carta Magna prevê ainda em seu artigo 214 que a Lei estabelecerá o Plano Nacional de Educação com duração decenal contendo objetivos, diretrizes, metas e estratégias de implementação para assegurar a manutenção e desenvolvimento do ensino em seus diversos níveis, etapas e modalidades. O PNE deve ser enviado pelo Poder Executivo ao Congresso Nacional para discussão e aprovação do projeto de lei. A questão principal é analisar a forma como o Poder Executivo e o Poder Legislativo conduzem esse trâmite. A primeira, exercendo o princípio da democracia deliberativa, chamou a sociedade para participar da construção do PNE, que ao ser apresentado ao Congresso já carregava demandas dos protagonistas dos movimentos da educação.

Isso demonstra, dentro do que se chama processo de políticas públicas, o primeiro momento de inclusão de determinado pleito ou necessidade social na agenda do poder público. Todas as discussões ocorridas nos fóruns e conferências trazem à tona questões que podem ser transformadas em problemas para, então, fazerem parte da agenda pública. Com a delimitação e identificação do problema, propõem-se possíveis alternativas para solucioná-los (SARAVIA, 2006). No caso em tela, o próprio PNE é um texto de proposições e soluções aos problemas anteriormente determinados.

Para tanto, será analisada quem são os grupos ali representados, a forma de atuação deles, suas relações com a arena parlamentar e com o Poder Executivo, bem como o entendimento de como esses movimentos de participação social contribuem para a constituição da agenda pública em torno do Plano Nacional de Educação.

\subsection{Problema de Pesquisa}

Nos últimos dez anos, houve aumento da participação social mediante conferências nacionais, as quais exercem impacto na formulação de políticas públicas e proporcionam mudanças na forma de fazer política do governo federal, impulsionando o Poder Legislativo a realizar suas atividades em observância à democracia participativa.

Foi possível perceber na elaboração do atual PNE que houve participação de inúmeros movimentos sociais. No entanto, ainda é preciso investigar em que medida houve participação social na formulação do II Plano Nacional de Educação em relação à construção 
das metas para a educação superior. E essa será a questão que a presente pesquisa tentará responder.

\subsection{Justificativa e Relevância}

Esse estudo se justifica pela necessidade de verificar se as mudanças que vem sendo empreendidas pela participação social mediante conferencias, de fato, impactam na formulação de políticas. A questão a analisar é se as iniciativas propostas por institutos de participação popular conseguem se fazer presentes na formulação de políticas públicas.

Com um governo que abraça discursos de participação social e que criou a Política Nacional de Participação Social por meio do Decreto $\mathrm{n}^{\mathrm{o}} 8.243$ de $2014^{1}$, para fortalecer as instâncias democráticas de diálogo entre a administração pública federal e a sociedade civil, deve ser capaz de trazer os cidadãos para dialogar sobre assuntos que antes ficavam restritos ao poder decisório dos burocratas e políticos. Além disso, precisa se comprometer em escutar a população e envolvê-la na formulação de políticas de Estado, o que exige um certo amadurecimento de ambas as partes. Do cidadão é necessário conhecimento e habilidade para conseguir se fazer escutar. Já ao governo cabe administrar os interesses de diversos grupos e discernir quais demandas atendem, de fato, o interesse público amplamente ou se restringe aos interesses de determinados grupos.

Assim, segundo Pogrebinschi (2013), a materialização da relação entre sociedade e conselhos se dá por meio das conferências nacionais, pois estas conseguem abordar problemas locais em âmbito nacional e, além disso, decisões individuais podem reverberar em escolhas sociais de política pública em espaços multiculturais e ambíguos. Por conseguinte, a participação social institucionalizada nas conferências é relevante, pois pode influenciar a formulação, implementação e avaliação de políticas públicas sendo um instrumento de gestão para a participação de grupos sub-representados nas esferas de poder.

Além disso, a relevância dessa pesquisa se dá porque trata da participação do cidadão na tentativa de solucionar os problemas por ele enfrentados. Quando a sociedade participa, ou no caso específico, - quando os movimentos de educação relacionados ao ensino superior se fazem ouvir, - há a possibilidade de contribui para a melhor adequação dos programas à realidade dos cidadãos. Outrossim, o cidadão tem papel relevante no alcance da efetividade das políticas públicas, tornando-se agente ativo na formação da agenda política.

\footnotetext{
${ }^{1}$ O Decreto Presidencial no 8.243/2014 foi rejeitado pelo plenário da Câmara dos Deputados em 28 de outubro de 2014. Em seu lugar foi proposto um Decreto Legislativo $\mathrm{n}^{\circ} 1.491 / 2014$ de autoria do deputado Mendonça | Filho_(DEM -PE) e aguarda apreciação pelo Senado Federal.
} 
Finalmente, os resultados deste trabalho verificaram se a participação social na Conae permitiu que a sociedade tivesse seus interesses representados e atendidos. A partir do momento em que o governo se mostra acessível às demandas da sociedade, os interesses coletivos da população serão efetivamente considerados e monitorados ao longo da realização das políticas públicas. Entende-se que tendo a população o poder de influenciar na elaboração de políticas, é o primeiro passo para ela cobrar melhores resultados das ações de governo.

\subsection{Objetivos}

O objetivo geral desse estudo é investigar a influência da participação social, por meio da Conferência Nacional de Educação, na formulação do II Plano Nacional de Educação, com ênfase nas políticas de educação do ensino superior. Além disso, se constituem como objetivos específicos dessa pesquisa:

a) Identificar e caracterizar os protagonistas que se envolveram no debate da política de educação de nível superior do PNE II (2014 - 2024) no âmbito da Conae;

b) Identificar o papel dos protagonistas na Conae para a formulação de políticas de educação de nível superior;

c) Compreender como se deu a atuação da Conae na elaboração do PNE II (2014 -2024) no que se refere às políticas de educação de nível superior;

d) Averiguar a percepção dos representantes governamentais e da sociedade civil sobre os objetivos, funcionamento e importância da Conae na formulação de políticas de educação relacionadas à educação de nível superior.

Essa dissertação está estruturada em cinco seções, incluindo esta introdução. A segunda seção é composta pelo referencial teórico, que se divide em: participação social, formação de agendas, formulação de políticas públicas e elaboração do Plano Nacional de Educação. Na terceira seção, será apresentado o método utilizado para o desenvolvimento da pesquisa, subdividindo-se nas seguintes subseções: tipo e desenho de pesquisa, coleta de dados e categorização e análise dos dados. Por fim, a quarta e a quinta seções descrevem os resultados da pesquisa, discutindo-os, bem como apresentam as considerações finais da pesquisa. 


\section{REFERENCIAL TEÓRICO}

O referencial teórico desse estudo baseia-se primeiramente nos fundamentos encontrados na literatura científica sobre o conceito de movimentos sociais e sua relação com a área de educação e a elaboração dos Planos Nacionais de Educação. Também serão discutidas definições sobre formação de agenda, formulação de políticas públicas, processo decisório e políticas públicas em educação.

Para tanto, estudar-se-ão as características dos movimentos sociais em educação que contam com a participação de intelectuais e professores reunidos em associações, sindicatos ou fóruns; os Planos Nacionais de Educação e o jogo de poder envolvido na articulação da elaboração desse plano. Será realizado um resgate histórico dos Planos Nacionais de Educação e as articulações estabelecidas com os movimentos sociais. Em um segundo momento, analisar-se-á o Plano Nacional de Educação e os movimentos sociais, bem como as forças atuantes a partir do estudo do projeto de lei apresentado até a aprovação da lei propriamente.

\subsection{Movimentos Sociais em Educação}

Os movimentos sociais têm participado dos processos decisórios junto ao Poder Público na resolução dos problemas que dizem respeito às políticas que interessam diretamente a sociedade. As ações dos movimentos sociais são múltiplas, diversas, cíclicas, com fluxos e refluxos. Em vista disso, tais movimentos são vistos como lutas não só pela ampliação do acesso ao espaço político, mas também pelo reconhecimento das aspirações populares, pois se concentram em vários problemas específicos, que, de modo geral, colocam os militantes em posição contrária a do poder instituído (GOHN, 2014).

Segundo Gohn (2014), existem basicamente três correntes teóricas sobre os movimentos sociais: a histórico-estrutural, a culturalista-identitária e a institucional/organizacional - comportamentalista. A primeira consiste na análise dos movimentos dos trabalhadores como sujeitos históricos. Essa é a matriz teórica de análise desenhada por Karl Marx. Nessa abordagem fundada na teoria marxista, o movimento social associa-se à ideia de lutas de classes, subordinando-se ao próprio conceito de lutas de classe. Estudos críticos inseriram na perspectiva marxista conceitos de reforma ou revolução. Isso leva os movimentos sociais a serem analisados como reformistas, reacionários ou 
revolucionários. Não se fazia uma dissociação do movimento social e político, pois as organizações eram vistas como suporte dos movimentos (GOHN, 2014).

A segunda corrente teórica, a culturalista-identitária, recebe influências variadas que vão desde o idealismo kantiano, passando pelo romantismo rousseauniano até o individualismo nietzchiano. Autores mais contemporâneos representam essa escola teórica. São eles: Habermas, Touraine, Arendt, Melucc e outros (GOHN, 2014). Esses autores focavam seus estudos na questão da identidade dos movimentos sociais e criticavam aqueles trabalhos que somente viam os estudos de classes sociais como categorias econômicas e que não consideravam a ação coletiva. Para Gohn (2014, p. 30), a contribuição dessa corrente foi a de "apresentar ao mundo a capacidade dos movimentos sociais de produzir novos significados e novas formas de vida e ação social”.

A corrente institucional/organizacional - comportamentalista foi desenvolvida nos Estados Unidos, mas também possui adeptos na Europa. Segundo essa teoria, as mobilizações sociais são estudadas sob a ótica econômica em que os objetivos são a organização, os interesses, recursos, estratégias; ou ainda, a ótica sociopsicológica que acredita que o movimento atinge os objetivos ao se transformar em organização institucionalizada (GOHN, 2014).

A discussão dos movimentos sociais na contemporaneidade insere-se em um campo de análise maior, o do surgimento de novas formas de racionalidades e o da crise da modernidade. Esta última decorrente das transformações societárias trazidas pela globalização, das alterações nos padrões das relações sociais etc. Assim, a agenda de pesquisas de movimentos sociais será retomada no final do século XX e início desse milênio para o estudo do movimento antiglobalização, enfatizando as redes que são construídas a partir deles, bem como ações comunitárias locais. Com isso o estudo de movimentos sociais não se restringe somente ao ambiente acadêmico, mas também é feito por organizações interessadas em obter dados para aprimorar seus planos e projetos (GOHN, 2014).

Ainda consoante Gohn (2014), as abordagens sobre ações e movimentos sociais desse milênio podem ser sintetizadas da seguinte forma: novos requerimentos da modernidade e a redefinição do sujeito racional de forma a incorporar as identidades culturais, a busca de um sujeito que articule o global com o local e as formas de democracia - deliberativa e participativa. É sobre este último tópico que se discorrerá nos parágrafos a seguir.

A questão da democracia deliberativa retoma a discussão de um discurso emancipatório, trazendo a ideia de que o movimento é um sujeito coletivo. As abordagens pós-estruturalistas assumirão a importância da linguagem, da produção de sentido, do 
simbólico, do discurso para a transformação da realidade social. As noções de democracia deliberativa remontam à Grécia clássica com a ideia de persuasão dos sofistas, perpassando pela Revolução Francesa até Marx Weber e Schumpeter que discutiram sobre as vantagens da argumentação na democracia. No entanto, a versão mais elaborada foi desenvolvida por Habermas e foi levada a público por Souza Santos (GOHN, 2014). Sendo assim, a afirmação que se extrai da ideia de democracia deliberativa é a de que a democracia não se legitima somente por meio do voto, mas também mediante discussões e decisões coletivas entre os cidadãos.

Para Leroux (2006), a democracia deliberativa possui duas entradas: a formação da vontade democrática constituída em espaços institucionais e em espaços extrainstitucionais, situados na sociedade civil, em sindicatos, em grupos de interesse etc. Isso quer dizer que essas duas faces devem se relacionar para caracterizar o governo democrático. Ainda conforme Gohn (2014, p. 55), “a política deliberativa seria o âmago do processo democrático, tendo vínculo com a sociedade por intermédio da opinião pública e do processo de formação de uma vontade coletiva”. Daí, a importância dos movimentos sociais, pois o processo reflexivo seria impulsionado por eles, construindo um modelo dialógico de intervenção pública.

Outro conceito fundamental desenvolvido pelo tema democracia deliberativa é o da sociedade civil que, segundo Leroux (2006), é heterogêneo e envolve várias fontes teóricas, mas pode ser sintetizado como o conjunto de movimentos, associações civis, organizações sociais, iniciativas cidadãs dentre outras que apresentam suas demandas e conquistam espaços de ação sociopolítica e cultural.

Diante do explanado, a democracia deliberativa apresenta um papel ambíguo por ser fonte de pressão de movimentos e precisar responder a um ativismo propositivo, organizado e ordenado institucionalmente como, por exemplo, pelos conselhos e fóruns criados pelo Estado. O que se vê na prática como solução desse impasse é que ou se resolve pelo conflito ou pela construção coesa de setores da sociedade civil (GOHN, 2014). Todo esse processo desenvolve novos conhecimentos e saberes que influenciam na forma como o governo e seus técnicos enxergam os problemas, impulsionando o desenvolvimento de soluções mais adequadas.

No contexto da América Latina, os movimentos sociais ganharam força quando a sociedade civil esteve sujeita a regimes autoritários. A exemplo disso, nasce no Brasil o Movimento Nacional de Educadores em 1970, sendo ele reconhecido como movimento social, pois apresenta três dimensões: identidade, oposição e totalidade (TOURAINE, 1973). 
Seguindo a lógica desse autor, a primeira dimensão é constituída pelo sujeito coletivo (intelectuais da educação, educadores). Já a segunda é representada pelo conflito que se instaura entre as políticas educacionais do mundo real e daquelas pautadas em uma agenda internacional. Por fim, a última refere-se à ação histórica dos atores sociais pertencentes ao movimento na sociedade com o objetivo de transformar a vida política, da produção econômica ou da estrutura jurídica e social e do cotidiano (TOURAINE, 1973).

No âmbito da educação, os movimentos sociais se caracterizam por serem formais, informais e não - formal. O primeiro se dá nas escolas. O segundo consiste na socialização dos indivíduos no ambiente familiar de origem. E o terceiro, são as práticas educativas de formação voltadas para a construção da cidadania (GOHN, 2012). Dessa forma, os movimentos pela educação ocorrem de dentro pra fora das escolas e em outros espaços institucionais. Consoante Gohn (2012, p. 346), as "lutas pela educação envolvem lutas por direitos e fazem parte da construção da cidadania".

Os movimentos sociais em educação abrangem diversas questões. Desde escolas até gêneros, etnia, nacionalidade, religiões, direitos humanos e culturais. E quanto ao aspecto histórico, os movimentos sociais, em 1960, focavam sua atuação mais em métodos de ensino. Em 1970, os movimentos sociais tiveram muito mais envolvidos com a universidade e com movimentos sociais urbanos que reivindicavam por melhorias nos transportes, creches, moradia etc, além de estarem envolvidos pela luta contra o regime militar. Em 1980, a relação dos movimentos sociais e da educação se acentua mediante trabalhos de educação popular e proposições para a constituinte. Segundo Gohn (2012, p. 347):

Os movimentos passaram a pautar uma nova agenda de demandas, e uma
nova cultura política também é construída, alterando as políticas públicas
vigentes. Conselhos e delegacias das mulheres, temas étnico-raciais,
ambientais etc. passaram a fazer parte do cotidiano na transição do regime
militar para a fase da redemocratização. Paulatinamente foram sendo
construídas redes de movimentos sociais temáticos

Esse cenário muda em 1990. Com o fim do regime militar e as novas configurações que assume o governo brasileiro, o país começa a reconstruir sua institucionalidade e outros atores entram em cena. Consoante Costa (2014, p. 88):

Embora a diversidade de práticas coletivas nem sempre sejam complementares, é possível identificar que há entre elas um elo que foi fortalecido em todo o processo de lutas e reivindicações contra as injustiças sociais, evolução da organização da educação e do sistema escolar no Brasil. Esse forte elo diz respeito ao enfrentamento às causas da desigualdade social como componente estrutural da sociedade brasileira, que em cada período histórico se apresenta com um formato específico, o que demanda por parte 
da sociedade civil organizada diferentes formas de lutas e reivindicações, assim como amplia e/ou ressignifica bandeiras de lutas e formas de resistência, mobilização e reivindicação.

Como fruto desse contexto de mudanças na atuação dos movimentos sociais é que se encontram oportunidades para pleitear as novas demandas. No dizer de Tarrow (2009), os movimentos sociais reagem ao encontrar oportunidades de ação usando-se de recursos externos para "escapar da submissão e encontra oportunidades para usá-los" (TARROW, 2009, p. 99). Esse movimento aumenta o confronto político. Para esse autor as oportunidades acontecem quando o acesso institucional se abre; quando há divisão nas elites, quando os aliados se tornam disponíveis e quando diminui a capacidade de repressão do Estado.

Com o novo cenário político brasileiro democrático, os movimentos sociais apresentam abertamente suas reivindicações, exigindo a implantação de um Sistema Político de Educação em detrimento das políticas fragmentadas que estavam vigentes. A partir desse momento, as lutas do ensino superior sempre estiveram relacionadas à contratação de professores, à expansão do ensino público, melhoria de qualidade da educação superior, cotas

e inclusão de estudantes de baixa renda ou em situação de vulnerabilidade social. É a partir dessas reivindicações que serão analisados nos espaços democráticos deliberativos conferências - a caracterização desses espaços e atores, as influências que eles exercem na formulação de políticas e as estratégias de atuação da CONED - Congresso Nacional de Educação - e da CONAE -Conferência Nacional de Educação.

\subsection{Planos Nacionais de Educação}

Nos parágrafos que se seguem serão explicitados o histórico e constituição dos Planos Nacionais de Educação, bem como a relação estabelecida entre o PNE e os movimentos sociais de educação. Serão analisadas as características dos movimentos sociais que participaram das discussões que nortearam os textos dos projetos de lei e que deram origem aos planos nacionais de educação, com ênfase no PNE II.

\subsubsection{Histórico e constituição}

A ideia de um Plano Nacional de Educação remete ao ano de 1930 no governo de Getúlio Vargas que discutia sobre a criação do Ministério da Educação e Saúde Pública (MASP), acerca da normatização de matérias pertinentes à educação e sobre a organização 
política de educadores. O Conselho Nacional de Educação foi instituído no ano seguinte pelo Decreto $\mathrm{n}^{\mathrm{o}}$ 19.850, de 11 de abril de 1931 e possuiu como atribuições fundamentais um corpo de normas que trouxeram a ideia de preparar um Plano Nacional de Educação (CURY, 2010).

No texto constitucional de 1934, em seu artigo 150 estava previsto como competência da União a criação de um Plano Nacional de Educação "compreensivo do ensino de todos os graus e ramos, comuns e especializados; e coordenar e fiscalizar a sua execução, em todo o território do País" (BRASIL/CF, 1934). Adicionalmente, o artigo 152 atribuía ao Conselho Nacional de educação à competência de elaborar o plano nacional de educação.

A concepção do Plano Nacional de Educação constituía na organização da educação do Brasil e fugia da prática de reformas pulverizadas e descontínuas (BOURDIGNON, QUEIROZ e GOMES, 2011). Com o CNE responsável pela elaboração do PNE e com o auxílio da Associação Brasileira de Educação (ABE) cuja recomendação era a de primar pela racionalidade técnica com o objetivo de dar autonomia aos educadores em relação aos programas governamentais. Essas ideias não chegaram a ser finalizadas e aplicadas, pois com o Golpe de Estado em 1937. Com a nova constituição, as diretrizes da educação se centralizam na União e, portanto, aquela ideia de participação de todos os entes propagada antes deixa de existir.

Esse cenário começa a mudar em 1945 quando da retomada do período democrático. Contudo, apesar de alguns avanços no quesito financiamento da educação com a constituição de um fundo para a educação primária, não houve uma preocupação de retomar as discussões sobre a elaboração de um a plano nacional de educação (DOURADO, 2011). No governo seguinte de Getúlio Vargas (1951 - 1954), as mudanças que ocorreram não foram estruturais e ficaram longe da proposta do primeiro de seu primeiro governo. O que marca aqui é a criação de órgão de administração superior a exemplo do Conselho Nacional de Pesquisa (CNPq) e a Coordenação de aperfeiçoamento de Pessoal de Nível Superior (CAPES). Além disso, houve a desvinculação do Ministério de Educação e Saúde.

Com o advento do governo de Juscelino Kubitschek em 1961 a ideia de plano retoma seu espaço no Plano de Metas. O tema educação inseria-se na meta 30 com o objetivo de atender a uma demanda do mercado orientada para o desenvolvimento econômico. Segundo Horta (1997), é a primeira vez que um governo apresenta a educação vinculada à ideia de desenvolvimento econômico. Concomitante a esse processo, ocorria discussão no Congresso Nacional sobre a Lei de Diretrizes e Bases da Educação Nacional (LDB). O principal debate que circundava a educação nesse momento era a questão do público e 
privado: se a gerencia da educação deveria ser exercida pelo Estado, visto como ineficiente, ou pelo setor privado.

Em meio a esse dilema, o Plano Nacional de Educação aprovado se resume a normatizar o financiamento da educação privada (escolas católicas em sua maioria) pelos recursos públicos. Em vista disso, constituíram-se os Fundo Nacional do Ensino Primário, o Fundo Nacional do Ensino Médio e o Fundo Nacional do Ensino Superior, com parcela de recursos federais (SAVIANI, 2010). Nesse contexto, o Conselho Nacional de Educação é substituído pelo Conselho federal de Educação (CEF) que implanta essas propostas anteriormente apresentadas.

O plano nacional que viria em seguida foi marcado por um contexto de mudanças políticas significativas. As reivindicações giravam em torno de reformas de base na educação e os movimentos da época eram escutados pelo então presidente João Goulart. A situação era marcada por intenta crise econômica e social, pois as taxas de desemprego e inflação aumentavam constantemente. Aliado a esse cenário de recessão econômica, havia um cenário de disputas políticas. Diante dessa situação, o Plano Nacional de Educação apresentado pelo Conselho Federal de Educação é suplantado pelo Plano Trienal de Educação que estava de acordo com o Plano Trienal de Desenvolvimento. Em seguida a essa tentativa de resolver a crise política e econômica, ocorre uma ruptura política e institucional e o Regime Militar se instaura a partir de 1964. Com os militares no poder há o abandono do Plano Trienal de Desenvolvimento e o surgimento do Plano Nacional de Desenvolvimento com seus planos setoriais. No caso da educação era intitulado Plano Setorial de educação e Cultura (PSEC). A Lei de Diretrizes e Bases da Educação foi descartada dando lugar às Leis 5.540/68 para a Educação Superior e 5.692/71 para o ensino de $1^{\circ}$ e $2^{\circ}$ graus.

A característica das reformas educacionais nesse período é de aliar a educação ao sistema ocupacional, subordinando a educação à produção. Os alunos saiam do $2^{\circ}$ grau para o mercado de trabalho. Para Germano (2011), isso representa uma contenção de demanda para a universidade o que contradiz o discurso da época que pregava "profissionalização para todos", um discurso quando na prática havia uma política discriminatória.

Em se tratando de políticas, Saviani (1996) afirma que o planejamento educacional assume um caráter tecnocrata, tendo em vista que o Ministério da Educação passa a se subordinar ao do Planejamento onde a maioria dos gestores possuía formação em ciências econômicas. A seguir a política educacional brasileira passa novamente por transformações com o advento da Constituição Federal de 1988 num contexto baseado por inúmeras mobilizações sociais e debates políticos: é a educação pós ditadura militar. 
A atuação da Associação Nacional de Docentes do Ensino Superior (ANDES) juntamente com a mobilização dos movimentos de estudantes, das Centrais Sindicais, e do Fórum Nacional em Defesa da Escola Pública trazem a tona as discussões acerca do Plano Nacional de Educação e o manifesto em defesa da escola pública e gratuita. Esses grupos tiveram um papel importante na elaboração do texto relativo à educação na Constituição Federal de 1998 (GOHN, 2010).

Como fruto do Manifesto em Defesa da Escola Pública, a Constituição Federal de 1988 entende a educação como um direito social, sendo o Estado seu provedor e, além disso, como sendo um instrumento necessário à construção do Estado de Direito. No dizer de Costa (2014, p. 78):

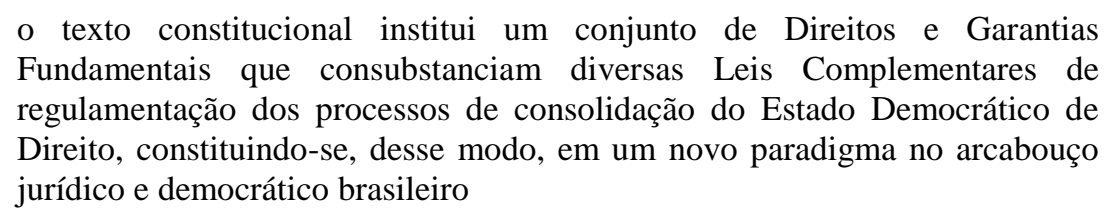

A parti daí, várias foram as emendas e Leis Complementares para assegurar a educação como Direito Social. Isso demonstra que os movimentos sociais estavam atentos e presentes nos momentos de disputas políticas e jurídicas e era também necessário para contribuir com uma sociedade democrática (COSTA, 2014).

O primeiro plano de educação, após a promulgação da $\mathrm{CF} / 88$, foi elaborado pelo MEC e chamava-se Plano Decenal de Educação para Todos. Este plano resulta do compromisso que o Brasil assumiu na Conferência Mundial de Educação para Todos realizada em 1990 pela UNESCO, UNICEF, PNED e Banco Mundial. Esse plano, segundo Dourado (2011), não foi utilizado no governo de Fernando Henrique Cardoso (FHC) como se verá a seguir.

\subsubsection{Planos Nacionais de Educação pós Constituição Federal de 1988}

Em 2009, a Emenda Constitucional n 59 dispõe que uma lei estabelecerá o plano nacional de educação, de duração decenal, com o objetivo de articular o sistema nacional de educação em regime de colaboração e definir diretrizes, objetivos, metas e estratégias de implementação para assegurar a manutenção e desenvolvimento do ensino em seus diversos níveis, etapas e modalidades por meio de ações integradas dos poderes públicos das diferentes esferas federativas. O plano elaborado pelo poder executivo é aprovado pelas casas legislativas e implantado por lei federal (BRASIL, 1988). 
O primeiro Plano Nacional de Educação pós Constituição Federal de 1988 (I PNE), foi aprovado em 2001 com validade de dez anos, sendo um instrumento que regeu a política de educação escolar. Dentre os seus objetivos estavam a elevação global do nível de escolaridade da população; a melhoria da qualidade do ensino em todos os níveis; a redução das desigualdades sociais e regionais no tocante ao acesso e à permanência, com sucesso, na educação pública e democratização da gestão do ensino público, nos estabelecimentos oficiais, obedecendo aos princípios da participação dos profissionais da educação na elaboração do projeto pedagógico da escola e a participação das comunidades escolares e local em conselhos escolares ou equivalentes (BRASIL, 2001).

O I PNE nasce na sociedade civil das deliberações do Fórum Nacional da Escola Pública sem que tenha havido um envolvimento dos órgãos do governo. O Fórum era integrado por mais de trinta entidades, entre elas a Associação Brasileira de Imprensa (ABI); Associação Nacional de Educação (ANDE); Sindicato Nacional dos Docentes das Instituições de Ensino Superior (ANDES-SN); Associação Nacional pela Formação dos Profissionais da Educação (ANFOPE); Associação de Dirigentes das Instituições Federais de Ensino Superior (ANDIFES); Associação Nacional de Política e Administração da Educação (ANPAE); Associação Nacional de Pesquisa e Pós-Graduação em Educação (ANPED); Conferência Nacional dos Bispos do Brasil (CNBB); Confederação Nacional dos Trabalhadores em Educação (CNTE); Confederação Nacional dos Trabalhadores em Estabelecimentos de Ensino (CONTEE); Conselho de Reitores das Universidades Brasileiras (CRUB); Central Única dos Trabalhadores (CUT); Federação de Sindicatos de Trabalhadores das Universidades Brasileiras (FASUBRA); Movimento dos Trabalhadores Sem-Terra (MST); Ordem dos Advogados do Brasil (OAB); União Nacional dos Dirigentes Municipais de Educação (UNDIME); União Nacional dos Estudantes (UNE), União Brasileira de Estudantes Secundaristas (UBES), entre outras (AGUIAR, 2010).

Essas entidades são resultado de uma conjuntura que vem se estruturando desde o final da década de 1970 e no início da de 1980. A sociedade civil reestruturou sua representação por meio de entidades. Iniciava-se a democratização do Estado brasileiro, exigindo a revitalização dos sindicatos, partidos políticos e associações, entre outras formas de organização da sociedade brasileira. Dessa forma, a Conferência Brasileira de Educação significava a retomada da agenda de luta pela educação pública e gratuita, recolocando na pauta a mobilização para a educação frente ao mandato de 1998/2002. A ideia era realizar um evento que envolvesse diferentes setores da sociedade civil para resgatar o papel da sociedade brasileira na elaboração de propostas para a educação (BOLLMANN, 2010). 
A materialização desses encontros foi o Plano Nacional de Educação, conhecido como PNE da Sociedade Brasileira, apresentado ao Congresso Nacional e protocolado como Projeto de Lei n. 4.155/98, encabeçado pelo deputado federal Ivan Valente e subscrito por mais de 70 parlamentares de todos os partidos e todos os líderes dos partidos de oposição da Câmara dos Deputados (VALENTE; ROMANO, 2002).

Diante dessa situação, dois dias depois o governo brasileiro apresentou sua Proposta ao Congresso Nacional. O texto foi elaborado pelo Instituto Nacional de Estudos e Pesquisas Educacionais Anísio Teixeira (INEP) "onde tramita de modo sui generis, como anexo ao PNE da Sociedade Brasileira, sob o número 4.173/98” (idem, ibid.).

Ainda na Câmara dos Deputados, foram realizadas audiências públicas com a participação de setores da sociedade (ANDES, ANDIFES, ANPED, UNDIME, CONSED Conselho Nacional de Secretários de Educação) e parlamentares de diversos partidos para discutir o PL n. 4.155/98. O relator do PL, Nelson Marchezan (PSDB), subscreveu o relatório (um substituto à proposta apresentada pela sociedade). A esse substitutivo foram apresentadas 158 emendas, sendo 71 aprovadas parcial ou totalmente.

O PNE foi aprovado pela Câmara dos Deputados no dia 14 de junho de 2000 e no dia 30 foi remetido ao Senado Federal onde recebeu a denominação de Projeto de Lei da Câmara (PLC) n. 42/2000, tendo como relator o senador José Jorge (PFL), na Comissão de Educação do Senado. Concomitante a esse processo, o Executivo divulga proposta para o PNE e convoca algumas entidades educacionais para participar dos debates sobre os temas Educação Fundamental, Educação Infantil, Ensino Médio e Ensino Superior (AGUIAR, 2010).

Dentre os convocados, estava a Associação Nacional de Pós-Graduação e Pesquisa em Educação (ANPED), que se manifestou criticamente à convocação do Executivo, conforme expôs em um parecer onde aponta a exiguidade do prazo para a manifestação das entidades da sociedade civil e ressalta que "o Plano Nacional de Educação deve ser formulado por meio de um processo participativo e aberto à contribuição de amplos setores da sociedade brasileira e, em especial, à contextualização da educação no bojo das políticas sociais, considerando-se o peso relativo destas no cômputo geral" (ANPED, 1997, p. 3).

A despeito dessas críticas, o projeto do Executivo tramitou no Congresso Nacional e teve sua aprovação em 9 de janeiro de 2000 por meio da Lei n. 10.172. Os vetos interpostos pelo então Presidente Fernando Henrique Cardoso, ao sancioná-lo, evidenciam as tensões e os conflitos presentes na luta da sociedade brasileira pelo reconhecimento da educação como direito social (AGIAR, 2010). 
Em sequência, como marco que antecede as discussões do atual PNE, encontra-se o lançamento em 2007 do Plano de Desenvolvimento da Educação - PDE, que reúne todos os programas em desenvolvimento pelo Ministério da Educação, ou seja, não apresenta novas propostas para a educação nacional, apenas expõe o que o Governo Federal vem implantando em todos os níveis da educação (SAVIANI, 2010).

O PDE, embora seja uma política de abrangência nacional, não se assume como política de Estado mesmo tendo tomado espaço do PNE/2001. É uma política de governo que dialoga com os movimentos sociais, mas que, nesse momento, se aproxima muito mais do empresariado da educação (MILITÃO, PERBONI, MILITÃO, 2011).

Com a formulação de um novo PNE para o próximo decênio, a discussão muda de foco do PDE para a relação que se estabelecerá entre ele e o novo PNE. E apesar dos avanços democráticos no que tange à participação social nos debates sobre o novo Plano de Educação, deve-se tratar com cautela a democratização das discussões, pois no primeiro PNE conceitos sobre educação e o papel do Estado na formulação e aplicação das políticas públicas educacionais foram relegados ao segundo plano (MILITÃO, PERBONI, MILITÃO, 2011).

Para a formulação do atual PNE, o governo federal preocupou-se em abrir espaço para a sociedade debater o tema educação. Isso foi viabilizado pela Conferência Nacional de Educação - Conae - que foi realizada em 2010. O documento final da Conae tenta atender a toda a demanda dos movimentos sociais. A decisão do governo era de submetê-lo ao debate social perpassando um processo de construção coletiva. O próprio documento apresenta a Conae como um "espaço democrático de construção de acordos sociais, que, expressando valores e posições diferenciadas sobre os aspectos culturais, políticos, econômicos, apontam renovadas perspectivas para a organização da educação nacional e para a formulação do Plano Nacional de Educação 2011-2020” (BRASIL, 2010, p. 110).

Assim, entende-se que a Conae propiciou o debate e a análise da educação brasileira entre acadêmicos e segmentos sociais ligados à educação cujos posicionamentos em relação à formulação de políticas educacionais eram divergentes. Corroborando a essa análise, Gouveia e Souza (2010, p. 804) afirmam que:

o documento Final da Conae pode ser um instrumento consistente para a formulação da política educacional a curto e médio prazo. Entretanto, o desafio político que se apresenta é tão rico quanto às formulações ali contidas, posto que se deva considerar que a arena pública de discussão que possibilitou o desenho de tal documento foi, pela primeira vez, composta por segmentos por vezes antagônicos no cenário educacional brasileiro. Entretanto, nem todos estes segmentos ocuparam com força total o campo de disputas. 
O documento enviado à Câmara dos Deputados que compôs o Projeto de Lei n. 8035/2010 não possuía o mesmo texto do documento final da Conae. O Poder Executivo apresenta um documento com teor diverso do definido na conferência, dando início ao trâmite parlamentar do Projeto de Lei n ${ }^{\circ}$ 8.035/2010. Em março de 2011, foi aprovada a criação da comissão especial que proferiu parecer sobre o projeto. Ela era composta por cinquenta deputados, sendo: 9 do PT, 10 do PMDB, 6 do PSDB, 4 do PP, 4 do DEM, 2 do PR, 3 do PSB, 2 do PDT, 2 do PTB, 2 do PSC, 2 do PCdoB, 1 do PRB, 1 do PSOL e o bloco PV-PPS com 2. Algumas mudanças ocorreram com o tempo pela mudança de partidos pelos políticos, mudando, com isso, a constituição inicial da comissão.

A partir desse momento, foram convocadas audiências públicas e seminários em diferentes cidades e mais tarde, em 20 de maio de 2011, foi aberto o prazo para a apresentação das emendas, tendo sido prorrogado por mais cinco sessões, encerrando-se em 7 de junho de 2011.

Ao fim, a comissão recebeu 2.915 emendas (BRASIL, 2014). A intervenção mais acentuada no texto original do atual PNE foi esperada nesse momento, pois é no Congresso Nacional no decorrer da tramitação do projeto de lei que as decisões são tomadas e convertidas em lei ao final do processo. E sabendo disso, os empresários da área de educação possuem atuação mais expressiva na arena parlamentar a fim de ter seus interesses acatados (SAVIANI, 2014).

Em vista disso, esses atores entendem que a Conferência Nacional de Educação é um lugar onde se debate e se discute ideias e se formulam propostas, mas não um lugar onde se tomam decisões definitivas. Saviani (2014) afirma que o espaço de tomada de decisões é ocupado pelas casas legislativas. Dessa forma, os empresários de ensino não se interessam em participar de conferências no estilo da Conae. A ideia é utilizar a arena parlamentar como instrumento que concretizará suas vontades mediante financiamento de campanha, por exemplo (SAVIANI, 2014).

Apesar dessa cooptação recorrente do parlamento por setores da iniciativa privada da educação, as emendas ao projeto de lei referidas no parágrafo anterior originaram-se da militância educativa da sociedade civil e subdividem-se da seguinte forma: 85 emendas da Campanha Nacional pelo Direito à Educação, 181 pela Associação Nacional dos Conselhos Municipais de Educação, 23 da União Nacional dos Conselhos Municipais de Educação, 206 do Centro de Estudos Educação e Sociedade, 50 da ministra Luiza Helena Bairros da Igualdade Racial, 60 da Confederação Nacional dos Trabalhadores da Educação e 41 do Fórum de Professores das Instituições Federais de ensino superior (SAVIANI, 2014). Ao todo 
foram 646 advindas da sociedade. Além disso, o projeto de lei foi analisado em diferentes regiões do país. Um exemplo disso é o Fórum Estadual de Educação do Paraná que enviou 1.424 propostas de emendas (SAVIANI, 2014).

Consoante Saviani (2014), as emendas surgiram de entidades representativas de educadores, apesar de seu grande número o que implica maior divergência entre elas, demonstrando que a sociedade civil está representada e participa do processo de onde emerge um plano mais próximo de suas necessidades, considerando que o texto enviado ao Congresso Nacional pelo Poder Executivo não representava o documento final fruto da Conae 2010. Dessa forma, foram enviados ao Senado Federal o texto integral do plano e o texto da lei que aprova o plano (idem).

A sanção pela Presidente da República do Projeto de Lei se deu em 25 de junho de 2014 cuja publicação ocorreu no dia 26 de junho, constituindo-se, então, como Lei no 13.005/2014. Ela apresenta 10 diretrizes e 20 metas. Dentre essas metas aquelas que se referem ao ensino de nível superior são as 12, 13 e 14 diretamente, e 15 e 16 indiretamente. O quadro a seguir explicitará na primeira coluna o projeto tal como foi apresentado, na segunda coluna a redação final com as alterações em negrito. 
Quadro 1: Comparativo entre versões do PNE II (Lei 13.005/2014)

\begin{tabular}{|c|c|}
\hline $\begin{array}{l}\text { PROPOSTA DO PROJETO DE LEI } \\
\qquad 8.035 / 2010 \text { (II PNE) }\end{array}$ & REDAÇÃO FINAL (LEI 13.005/2014) \\
\hline $\begin{array}{l}\text { Meta 12: Elevar a taxa bruta de matrícula na } \\
\text { Educação Superior para } 50 \% \text { e a taxa líquida para } \\
33 \% \text { da população de } 18 \text { a } 24 \text { anos, assegurando } \\
\text { a qualidade da oferta. }\end{array}$ & $\begin{array}{l}\text { Meta 12: Elevar a taxa bruta de matrícula na Educação } \\
\text { Superior para } 50 \% \text { (cinquenta por cento) e a taxa líquida } \\
\text { para } 33 \% \text { (trinta e três por cento) da população de } 18 \text { a } \\
24 \text { anos, assegurando a qualidade da oferta e } \\
\text { expansão para, pelo menos } \mathbf{4 0 \%} \text { (quarenta por } \\
\text { cento) das novas matrículas, no segmento público. }\end{array}$ \\
\hline $\begin{array}{l}\text { Meta 13: Elevar a qualidade da Educação } \\
\text { Superior pela ampliação da atuação de mestre e } \\
\text { doutores nas instituições de educação superior } \\
\text { para } 75 \% \text {, no mínimo, do corpo docente em } \\
\text { efetivo exercício, sendo do total } 35 \% \text { doutores. }\end{array}$ & $\begin{array}{l}\text { Meta 13: Elevar a qualidade da Educação Superior e } \\
\text { ampliar a proporção de mestre e doutores do corpo } \\
\text { docente em efetivo exercício no conjunto do sitema } \\
\text { de educação superior para } 75 \% \text { (setenta e cinco por } \\
\text { cento), sendo do total, no mínimo, de } 35 \% \text { (trinta e } \\
\text { cinco por cento) doutores. }\end{array}$ \\
\hline $\begin{array}{l}\text { Meta 14: Elevar gradualmente o número de } \\
\text { matrículas na Pós-Graduação stricto sensu, de } \\
\text { modo a atingir a titulação anual de sessenta mil } \\
\text { mestres e vinte e cinco mil doutores. }\end{array}$ & $\begin{array}{l}\text { Meta 14: Elevar gradualmente o número de matrículas } \\
\text { na Pós-Graduação stricto sensu, de modo a atingir a } \\
\text { titulação anual de } 60.000 \text { (sessenta mil) mestres e } \\
25.000 \text { (vinte e cinco mil) doutores. }\end{array}$ \\
\hline $\begin{array}{l}\text { Meta 15: Garantir, em regime de colaboração } \\
\text { entre a União, os Estados, o Distrito Federal e os } \\
\text { Municípios, que todos os professores da } \\
\text { Educação Básica possuam formação específica } \\
\text { de nível superior, obtida em curso de licenciatura } \\
\text { na área de conhecimento em que atuam. }\end{array}$ & $\begin{array}{l}\text { Meta 15: Garantir, em regime de colaboração entre a } \\
\text { União, os Estados, o Distrito Federal e os Municípios, } \\
\text { no prazo de } 1 \text { (um) ano de vigência deste PNE, } \\
\text { política nacional de formação dos profissionais da } \\
\text { educação de que trata os Incisos I, II e III do caput } \\
\text { do Art. } 61 \text { da lei } 9.394 \text { de } 20 \text { de dezembro de } 2006 \text {, } \\
\text { assegurando que todos os professores(as) da } \\
\text { Educação Básica possuam formação específica de } \\
\text { nível superior, obtida em curso de licenciatura na } \\
\text { área de conhecimento em que atuam. }\end{array}$ \\
\hline $\begin{array}{l}\text { Meta 16: Formar } 50 \% \text { dos professores da } \\
\text { Educação Básica em nível de Pós-Graduação lato } \\
\text { e strcto sensu e garantir a todos formação } \\
\text { continuada em sua área de atuação }\end{array}$ & $\begin{array}{l}\text { Meta 16: Formar em nível de Pós-Graduação, 50\% } \\
\text { (cinquanta por cento) dos professores da Educação } \\
\text { Básica em nível de Pós-Graduação, até o último ano de } \\
\text { vigência deste PNE, e garantir a todos(as) profissionais } \\
\text { de Educação Básica formação continuada em sua área } \\
\text { de atuação, considerando as necessidades, demandas e } \\
\text { contextualizações do sistema de ensino. }\end{array}$ \\
\hline
\end{tabular}

Fonte: Elaborado pela autora a partir das emendas ao Projeto de Lei 8035/2010 
As mudanças identificadas no texto das metas deslocadas de uma análise mais minuciosa dos embates que ocorreram nas casas legislativas (que não se encontra como objetivo desse estudo), não levam a identificar modificações substanciais do que foi proposto pela Poder Executivo, contudo é um texto distante do documento final apresentado pela Conae. Ao analisarmos com mais cautela, as alterações no conteúdo mostram a linha ténue que se percorre para decidir entre o que dado grupo considera ser o melhor e o que de fato se consegue fazer.

Ao analisar o quadro, percebe-se que há uma tentativa de se instituir uma visão sistêmica da educação, em se tratando, sobretudo, das metas 14, 15 e 16. Elas intencionam a integração dos vários níveis de educação de forma que as metas do II PNE “estão organizadas de maneira a representar um conjunto de medidas enfaixadas por uma orientação abrangente que tem como pressuposto a concepção sistêmica de educação" (CÂMARA DOS DEPUTADOS, 2011, p. 67).

Em se tratando de educação de nível superior há que se destacar dois programas que efetivaram, mesmo antes da aprovação do II PNE, a reivindicação da sociedade civil: Programa de Apoio a Planos de Reestruturação e Expansão das Universidades Federais (REUNI) e Programa Universidade para Todos (PROUNI). O REUNI foi instituído pelo Decreto $n^{\circ}$ 6.096, de 24 de abril de 2007 com o objetivo de ampliar o acesso das instituições federais. Por meio dele as instituições se expandiram física, acadêmica e pedagogicamente. Já o PROUNI foi instituído pela Lei 11.096/2005 e objetivava a concessão de bolsas para alunos de baixa renda para instituições de educação de nível superior privado. Do que se extrai do texto da Conae é a de que se deveriam expandir as instituições federais públicas de ensino atrelado ao incentivo de programas de ações afirmativas como, por exemplo, políticas de promoção da igualdade racial e gradualmente extinguir formas de financiamento da educação privada. Algumas questões foram atendidas e outras não, conforme se observa no quadro anterior.

Para finalizar essa seção, observa-se que no primeiro PNE, a influência neoliberal dos anos de 1990 alijou a sociedade civil do debate político, dando origem a um documento fruto de debates cujas ideologias mercadológicas impregnaram a discussão sobre educação. Ele é percebido mais como uma carta de intenções do que como ações articuladas que impactam na educação pública (OLIVEIRA, 2010).

Enquanto que no PNE 2014-2024, o que aconteceu foi a inserção da sociedade civil no processo decisório até certo momento. A sociedade teve grande abertura para 
participar até o momento da tramitação do projeto na Câmara dos Deputados. No segundo momento em que o projeto encaminhou-se para a casa legislativa do Senado, pontos de grande importância foram tratados pelos arranjos que ali se fizeram, sendo que o objetivo desses arranjos é justamente promover o insulamento do eleitorado, sendo menos sujeito às demandas de cidadãos e mais propensos à satisfação de seus interesses.

\subsubsection{Planos Nacionais de Educação e Movimentos Sociais}

Para entender o processo que desencadeou a formulação dos planos nacionais de educação, busca-se pelos elementos constitutivos desse processo. Para essa análise, é necessário averiguar quem participou da construção dos planos, se houve consenso nas discussões, o envolvimento dos Poderes Legislativo e Executivo e, em resumo, de que forma os movimentos sociais participaram e contribuíram para a formulação de documentos que mais tarde se transformaram em Planos Nacionais de Educação.

Diante disso, compreender o papel desempenhado pelo Fórum Nacional de Defesa da Escola Pública para a elaboração do PNE - Proposta da Sociedade Brasileira - e, além deste, a Conferência Nacional de Educação - CONAE, para a elaboração do segundo PNE, requer entender a participação da sociedade civil na construção de políticas educacionais que contribuíram para a educação pública gratuita e de qualidade.

Em 1986 nasce o Fórum Nacional pela Constituinte, que mais tarde se transforma em Fórum Nacional em Defesa pela Escola Pública (FNDEP), atuando em diferentes momentos da política educacional. Um exemplo disso foi a elaboração e construção do Projeto de Lei de Diretrizes e Bases da Educação Nacional, a conhecida LDB do Fórum, no período entre 1988 a 1996, bem como da aprovação na Constituição Federal do Capítulo III, Seção I, intitulado Da Educação.

Passado esse momento, o Fórum reivindica uma nova LDB, uma vez que aquela construída pelo Fórum não foi aprovada pelo Congresso Nacional, sendo substituída pela Lei n. 9.394/1996. Esta é fruto do PL n. 73/95 apresentado pelo Senador Darcy Ribeiro do Partido Democrático Trabalhista - PDT - que desconsiderou o trabalho apresentado pelas entidades do FNDEP.

Neste momento, integravam o FNDEP mais de trinta entidades. São elas: Associação Brasileira de Imprensa (ABI); Associação Nacional de Educação (ANDE); Sindicato Nacional dos Docentes das Instituições de Ensino Superior (ANDES-SN); Associação Nacional pela Formação dos Profissionais da Educação (ANFOPE); Associação 
de Dirigentes das Instituições Federais de Ensino Superior (ANDIFES); Associação Nacional de Política e Administração da Educação (ANPAE); Associação Nacional de Pesquisa e PósGraduação em Educação (ANPED); Conferência Nacional dos Bispos do Brasil (CNBB); Confederação nacional dos Trabalhadores em Educação (CNTE); Confederação Nacional dos Trabalhadores em Estabelecimento de Ensino (CONTEE); Conselho de Reitores das Universidades Brasileiras (CRUB); Central Única dos Trabalhadores (CUT); Federação de Sindicatos de Trabalhadores das Universidades Brasileiras (FASUBRA); Movimento dos Trabalhadores Sem-Terra (MST); Sindicato Nacional dos Servidores Federais da Educação Básica e Profissional (SINASEFE); Ordem dos Advogados do Brasil (OAB); União Nacional dos Dirigentes Municipais de Educação (UNDIME); União Nacional dos Estudantes (UNE); União Brasileira de estudantes Secundaristas (UBES) e, por fim, composição suprapartidária do Fórum (BOLLMANN, 2010).

Na década de 1990, a mobilização da sociedade civil pela educação continua presente, sendo o FNDEP o espaço onde as discussões acontecem. Perante o contexto de abertura econômica e globalização ${ }^{2}$, o FNDEP enxerga a necessidade da continuidade e ampliação do debate nacional acerca das consequências de propostas dos organismos internacionais sobre a educação, materializadas em decretos, leis, emendas constitucionais e medidas provisórias que criavam mecanismos de facilitação à privatização da educação, sobretudo do ensino superior (BOLLMANN, 2010).

Nesse contexto, percebe-se que o Estado brasileiro se vincula historicamente aos interesses do setor privado caracterizando-se por adotar políticas de ajuste estruturais recomendadas pela Organização Mundial do Comércio (OMC), Fundo Monetário Internacional (FMI) e Banco Interamericano de Desenvolvimento (BID). As mudanças desencadeadas pela transferência de prestação de serviços públicos pela iniciativa privada despertam em setores de esquerda da sociedade, em partidos políticos e em algumas instituições governamentais o interesse de conceber propostas que representassem o interesse da sociedade.

\footnotetext{
${ }^{2}$ A ideia de abertura econômica e financeira e globalização adotada nesse ponto advém do conceito de Chesnais que utiliza o termo "mundialização financeira" para tratar do tema, conceituando-a como "estreitas interligações entre os sistemas monetários e os mercados financeiros nacionais, resultantes da liberalização e desregulamentação adotadas inicialmente pelos Estados Unidos e pelo Reino Unido, entre 1979 e 1987, e nos anos seguintes pelos demais países industrializados. A abertura, externa interna, dos sistemas nacionais, anteriormente fechados e compartimentados, proporcionou a emergência de um espaço financeiro mundial. Nem por isso os sistemas financeiros nacionais foram eliminados com a liberalização e desregulamentação" (CHESNAIS, p. 12).
} 
Nesse momento, os representantes da sociedade no âmbito da educação eram: Sindicato Nacional dos Docentes do Ensino Superior (ANDES-SN); Federação Sindicatos de Trabalhadores das Universidades Brasileiras (FASUBRA Sindical), Confederação Nacional dos Trabalhadores em Educação (CNTE); Confederação Nacional dos Trabalhadores em Estabelecimentos de Ensino (CONTEE); Movimento dos Trabalhadores Sem-Terra (MST); Sindicato Nacional dos Servidores Federais da Educação Básica e Profissional (SINASEFE), União Nacional de Dirigentes Municipais de Educação (UNDIME), União Nacional dos Estudantes (UNE); União Brasileira de Estudantes Secundaristas (UBES); Associação Nacional pela Formação dos Profissionais da Educação (ANFOPE); Associação Nacional de Educação (ANDE); Associação Nacional de Política e Administração da Educação (ANPAE); Associação de Educadores Latino-Americanos e do Caribe (AELAC); Comissão Nacional de Assuntos educacionais do Partido dos Trabalhadores (CAED/PT); Confederação Nacional dos Servidores Públicos Federais (CONDISEF) e representantes de Fóruns Estaduais em Defesa da Escola Pública (idem).

Foi a partir desse cenário que, nas décadas de 1980 e 1990, as Conferências Brasileiras de Educação (CEB) emergiram trazendo a possibilidade de discussão sobre alternativas para a educação que passava por um momento de crise por causa de acordos internacionais ainda do período da ditadura militar. Com isso, foram realizadas as seguintes conferências: I CEB (São Paulo, 1980) que tratava sobre "Política Educacional"; II CBE (Belo Horizonte, 1982) abordando o tema "Educação: perspectivas na democratização da sociedade"; III CBE (Niterói, 1984) com o tema "Das críticas às propostas de ação"; IV CBE (Goiânia, 1986) sobre "Educação e Constituinte"; CBE (Brasília, 1989), com o tema "Lei de Diretrizes e Bases da Educação Nacional: compromisso dos educadores" e VI CBE (São Paulo, 1991) (BOLLMANN, 2010).

Ainda, segundo Bollmann (2010, p. 664), era "preciso construir, democraticamente, uma nova proposta de educação para o país [...] retomando a agenda de luta pela educação pública e privada [...] recolocando na pauta a mobilização para a educação frente ao mandato de 1998/2002”.

Já na década de 1990 e ainda imbuídos desse espírito de participação social e com o intuito de ampliar a sua participação na construção de uma proposta de educação, pela sociedade organizada, alternativa ao modelo proposto pelos organismos internacionais e pelo governo brasileiro, o FNDEP decide realizar uma reunião com mais de 15 entidades em 1996 na Universidade de São Paulo (DOURADO, 2010). Esse movimento dá origem aos Congressos Nacionais de Educação - CONED - que são espaços organizados para a 
elaboração democrática de propostas que contemplassem os anseios e a concepção de educação, estado e sociedade das entidades que integraram o Fórum.

Segundo Perez (2009), espaços como o Coned são considerados instituto de participação popular, que vem a ser a integração direta e indireta de cidadãos na execução da função administrativa. Para o ordenamento jurídico brasileiro, os institutos de participação popular devem representar a verdadeira abertura da participação, possibilitando a participação da sociedade tanto na gestão de políticas como também no controle da Administração Pública cujos objetivos são tornar eficiente a execução das diferentes tarefas administrativas e dar efetividade aos direitos fundamentais. O que caracteriza de fato um instrumento como instituto de participação popular é o fato de nele participar diferentes segmentos da sociedade com interesses na eficiência da atuação estatal em determinada área social. Os institutos de participação popular na Administração Pública são (PEREZ, 2009. p. 94):

\footnotetext{
institutos políticos voltados à obtenção de resultados (ou decisões) de soma positiva - decisões que em geral produzem mais vantagens do que desvantagens para todos os envolvidos - que, por assim ser, resultam imprescindivelmente de 'uma mistura de cooperação e conflito'. Uma vez inexistente a possibilidade de se confrontarem os polos opostos, no jogo dos interesses sociais, impossível se torna a cooperação, o conflito e a obtenção de decisões no interesse de todos, com soma positiva.
}

Ao todo, foram realizados cinco Coned de 1996 a 2005. Contudo, as discussões que se consolidaram no plano conhecido como PNE - Proposta da Sociedade Brasileira duraram dois anos (1996 e 1997) (DOURADO, 2010). O I Congresso Nacional de Educação ocorreu em Belo Horizonte - MG, em 1996 e possuiu o objetivo de organizar a intervenção nos processos de elaboração e tramitação da LDB, bem como, apresentar as diretrizes do PNE - Proposta da Sociedade Brasileira. O tema central era "Construindo um Plano Nacional de Educação" que se subdividiu em cinco subtemas: Plano de Educação: Estado e Educação; Sociedade civil e Educação; Trabalho e Educação; Educação Básica e Educação Superior (idem).

Em 1997, ainda em Belo Horizonte, acontece o II Congresso Nacional de Educação, em meio às questões que permearam a promulgação da LDB. Com isso, o FNDEP promove atividades que culminaram o II Coned e que culminou com a consolidação do PNE com diretrizes divergentes da política educacional do então governo de Fernando Henrique Cardoso e do ministro Paulo Renato. Assim, o II Coned caracterizou-se por desenvolver seminários temáticos nacionais, regionais e locais, sendo o tema e os subtemas definidos a partir dos temas organizativos do PNE que tratava desde a Organização da Educação Nacional, Gestão Democrática da Educação perpassando pelo Financiamento da educação e, 
por fim, Modalidades e Níveis de Educação. Ainda consoante Bollmann (2010, p. 668), o PNE configura-se como um documento "cujo caráter extrapola o mero documento formal e se transforma em um referencial político de atuação".

O III Congresso Nacional de Educação acontece em Porto Alegre no ano de 1999 em um contexto de disputa de projetos educacionais com a tentativa de reproduzir o feito anterior de conduzir todo o processo democrático de elaboração de propostas alternativas de educação. O IV Coned ocorreu em São Paulo, em 2002, em meio ao enfrentamento dos dois projetos de educação: o do governo FHC e o do FNDEP. Com a aprovação do primeiro intitulado como Lei n. 10.172/2001.

No V Coned que se realizou em Recife no ano de 2005 a conjuntura é de discussão das consequências das políticas adotadas nos últimos 15 anos nas áreas sociais. $\mathrm{O}$ tema desse encontro era: Educação não é mercadoria. A questão principal gira em torno da direção política em que a produção do conhecimento vem tomando em todas suas instâncias e leva ao processo de privatização da educação, sobretudo do ensino superior com $75 \%$ das matrículas em instituições privadas. Nesse âmbito, contrapondo-se ao que ocorre na prática, a principal reivindicação era a ampliação do número de vagas do ensino superior público (BOLLMANN, 2010).

A continuidade desse processo é materializada pela I Conferência Nacional de Educação - CONAE 2010 - que passa a atuar em momento diferente da política educacional brasileira com a participação da sociedade. Em 2008 uma portaria ministerial constitui uma comissão de 35 membros a quem são atribuídas as tarefas de coordenar, monitorar e promover o desenvolvimento da Conae.

Essa comissão organizadora é composta tanto por membros do executivo quanto por entidades representantes da sociedade no âmbito da educação. São elas: Associação Nacional dos Dirigentes das Instituições Federais de Ensino Superior - ANDIFES; Associação Brasileira dos Reitores das Universidades Estaduais e Municipais - ABRUEM; Confederação Nacional de Estabelecimentos de Ensino - CONFENEN; Associação Brasileira das Universidades Comunitárias - ABRUC Conselho de Dirigentes dos Centros Federais de Educação Tecnológica - CONCEFET; Conselho Nacional de Secretários de Educação CONSED; União Nacional dos Dirigentes Municipais de Educação - UNDIME; Confederação Nacional dos Trabalhadores em Educação - CNTE; Confederação Nacional dos Trabalhadores em Estabelecimentos de Ensino - CONTEE; Federação de Sindicatos de Trabalhadores de Universidades Brasileiras - FASUBRA; Sindicato Nacional dos Docentes das Instituições de Ensino Superior - ANDES/SN; Fórum de Professores das Instituições 
Federais de Ensino Superior - PROIFES; Sindicato Nacional dos Servidores Federais da Educação Básica e Profissional - SINASEFE; Fórum Nacional dos Conselhos Estaduais de Educação - FNCEE; União Nacional dos Conselhos Municipais de Educação - UNCME; União Brasileira dos Estudantes Secundaristas - UBES; União Nacional dos Estudantes UNE; Confederação Nacional das Associações de Pais de Alunos - CONFENAPA; Representação da Comunidade Científica; Representação Social do Campo; Representação dos Movimentos de Afirmação da Diversidade; Representação das Articulações Sociais em Defesa da Educação; Representação das Entidades de Estudos e Pesquisa em Educação; Representação das Centrais Sindicais dos Trabalhadores; Representação das Confederações dos Empresários e do "Sistema S" (BOLLMANN, 2010).

A Conae 2010 foi precedida por etapas municipais, estaduais e distrital. Ao todo, foram realizadas trezentas e setenta e oito conferências municipais em cidades do Tocantins, Sergipe, São Paulo, Santa Catarina, Rondônia, Rio Grande do Sul, Rio Grande do Norte, Rio de Janeiro, Piauí, Pernambuco, Paraná, Paraíba, Minas Gerais, Distrito Federal, Ceará, Bahia e Alagoas. No âmbito estadual foram realizadas em todos os estados de todas as regiões do Brasil as conferências estaduais.

O objetivo principal dos fóruns e conferências estaduais e municipais era discutir sobre o Documento-Referência da Conae (documento este elaborado pela Comissão de Organizadora Nacional), a Educação Básica e o Ensino Superior contemplando suas etapas e modalidades de ensino.

Todas as discussões e deliberações realizadas nas etapas estaduais e municipais foram sistematizadas e apresentadas na Conae 2010 para novas discussões e deliberações. Para melhor cumprir com objetivos propostos, a Comissão Organizadora Nacional constituiu comissões especiais para executar ações referentes a todas as outras etapas da conferência: comissão de Divulgação e Mobilização; comissão de Dinâmica e Sistematização e comissão de Infraestrutura e Logística e, ainda, com o objetivo de assegurar a existência de um relatório final que pudesse contribuir para a formulação das ações subsequentes, foi designado, pela Comissão Organizadora Nacional, um grupo de trabalho especial encarregado da sistematização e elaboração do documento final da Conae que foi presidido pelo coordenador da Comissão Organizadora da Conae.

O tema das etapas estaduais e municipais de educação foi: "Construindo o Sistema Nacional Articulado de Educação: Plano Nacional de Educação, Diretrizes e Estratégias de Ação" que deve ser discutido a partir dos seguintes eixos temáticos: a) Papel do Estado na Garantia do Direito à Educação de Qualidade: Organização e Regulação da Educação Nacional; b) 
Qualidade da Educação, Gestão Democrática e Avaliação; c) Democratização do Acesso, Permanência e Sucesso Escolar; d) Formação e Valorização dos/das Profissionais da Educação; e) Financiamento da Educação e Controle Social; f) Justiça Social, Educação e Trabalho: Inclusão, Diversidade e Igualdade.

Tendo isso em mente, as Conferências Municipais debateram e contribuíram com propostas ao Documento-Referência e este, composto pelas emendas deliberadas, foi encaminhado às Conferências Estaduais. Nessas últimas foram também deliberadas proposições de mudanças, supressões ou acréscimos que ao fim foram apresentados na Conferência Nacional.

Como resultado desse processo, foram enviadas 5.300 propostas e a participação de 2.800 delegados das 27 unidades da federação (FERNADES, 2010). Com isso, os movimentos sociais de educação esperavam que a participação ampla servisse para se discutir sobre a proposta de um Sistema Nacional de Educação. Ainda, consoante Fernandes (2010, p. 3), é por meio da "visão sistêmica que se busca implementar com a participação dos entes federados objetivando instituir uma cultura de maior articulação e melhoria nos processos de gestão de políticas, programas e ações direcionados a otimização do acesso e dos processos de gestão com a garantia de qualidade".

Além disso, a ideia de um sistema engloba conceitos como gestão democrática, qualidade, regulação, financiamento e definição de custo aluno/qualidade, formação e qualificação de profissionais da educação, ampliação de oportunidades e melhoria do processo de ensino aprendizagem Um aspecto importante dessa proposta é que além de se fazer um diagnóstico da educação no Brasil foi feita uma avaliação do PNE anterior. Isso de fato contribui para uma análise de pontos que necessitam de aprimoramento nas políticas (FERNANDES, 2010).

Após as etapas municipais e estaduais, de 28 de março a $1^{\circ}$ de abril de 2010 , ocorreu em Brasília a Conferência Nacional de Educação (CONAE). Desse encontro, nasceu o documento que foi apresentado ao Poder Executivo dividido em seis eixos: Papel do Estado na Garantia do Direito à Educação de Qualidade: Organização e Regulação da Educação Nacional; Qualidade da Educação, Gestão Democrática e Avaliação; Democratização do Acesso; Permanência e Sucesso Escolar; Formação e Valorização dos/das Profissionais da Educação; Financiamento da Educação e Controle Social e Justiça Social Educação e Trabalho: Inclusão, Diversidade e Igualdade (idem).

A realização de conferências, sobretudo da forma como vêm sendo estruturadas, é válida para mudar a forma de fazer política do governo federal, pois fortalece a democracia 
mediante a prática participativa e deliberativa (AVRITZER, 2012). Os movimentos sociais ao se articularem para participar do processo de construção do Plano Nacional de Educação contribuem para tal fortalecimento.

Os movimentos sociais de educação desde a década de 1980 até os dias de hoje permanecem com uma composição bastante similar. Percebe-se que na formulação dos PNEs não houve significativas mudanças com relação à participação dos grupos da sociedade civil organizada. E nos momentos de discussão sobre os Planos o objetivo de lutar pelo ensino público e de qualidade sempre prevaleceu apesar dos desfechos que se apresentaram (SAVIANI, 2012).

Ainda nesse contexto sobre Conferências como institutos em que movimentos sociais encontram espaços legítimos de discussão de ideias sobre determinada temática, uma análise de Avritzer (2012) aponta que de 2003 a 2010 (período em que a pesquisa foi feita) no quesito participação por área temática, a educação encontra-se em quinto lugar atrás de áreas como políticas para mulheres, direitos humanos, assistência social e cultura. Para esse mesmo autor, essa configuração reside no fato de ter havido uma redefinição das áreas de interesse dos atores da sociedade civil no Brasil.

Tabela 2: Participação da sociedade civil organizada de acordo com a temática da conferência

\begin{tabular}{l|c|c|r}
\hline \multicolumn{4}{c}{ Se já participou, em qual temática? } \\
\hline Assistência Social & Participantes & \% & \multicolumn{1}{c}{ Total } \\
\hline Comunicação & 52 & 36,4 & 143 \\
\hline Cultura & 16 & 11,2 & 143 \\
\hline Cidades & 42 & 29,4 & 143 \\
\hline Direitos humanos & 15 & 10,5 & 143 \\
\hline Educação & 56 & 39,2 & 143 \\
\hline Esportes & 27 & 18,9 & 143 \\
\hline Juventude & 23 & 16,1 & 143 \\
\hline Política das Mulheres & 16 & 11,2 & 143 \\
\hline Saúde & 64 & 44,8 & 143 \\
\hline Saúde Mental & 12 & 8,4 & 143 \\
\hline Segurança alimentar e nutricional & 16 & 11,2 & 143 \\
\hline Segurança pública & 5 & 3,5 & 143 \\
\hline
\end{tabular}

Fonte: Avritzer (2012), com base na pesquisa PRODEP/Vox Populi.

A outra categoria pesquisada mostra a intensidade de participação. E nesse quesito as áreas clássicas de participação dos atores da sociedade civil brasileira figuram no topo da lista. A educação está em segundo lugar empatada com assistência social, só abaixo da saúde. 
Tabela 3: Conferência em que a sociedade civil organizada participou mais ativamente

\begin{tabular}{l|c|c}
\hline \multicolumn{1}{c}{ Das conferências que acompanhou, qual participou ativamente? } \\
\hline \multicolumn{1}{c}{ Temática } & Frequência & $\%$ \\
\hline Assistência Social & 17 & 11,9 \\
\hline Comunicação & 2 & 1,4 \\
\hline Cultura & 12 & 8,4 \\
\hline Cidades & 2 & 1,4 \\
\hline Direitos humanos & 5 & 3,5 \\
\hline Educação & 17 & 11,9 \\
\hline Esportes & 11 & 7,7 \\
\hline Juventude & 4 & 2,8 \\
\hline Política das Mulheres & 5 & 3,5 \\
\hline Saúde & 21 & 14,7 \\
\hline Saúde Mental & 1 & 0,7 \\
\hline Segurança alimentar e nutricional & 2 & 1,4 \\
\hline Segurança pública & 9 & 6,3 \\
\hline Criança e adolescente & 1 & 0,7 \\
\hline Logistíca & 1 & 0,7 \\
\hline Drogas & 2 & 1,4 \\
\hline Conselho de classe, professores e mestres & 1 & 0,7 \\
\hline Meio ambiente & 1 & 0,7 \\
\hline Orçamento participativo & 1 & 0,7 \\
\hline NR & 28 & 19,6 \\
\hline Total & 143 & 100 \\
\hline
\end{tabular}

Fonte: Avritzer (2012), com base na pesquisa PRODEP/Vox Populi.

Isso demonstra, conforme Avritzer (2012), que há uma participação efetiva nas conferências nacionais e que expressa continuidade com as formas de participação que surgiram no Brasil durante a redemocratização. E a educação está entre as áreas em que a participação em conferências foi determinante para a sociedade civil organizada se fazer presente na formulação do documento que mais tarde será o PNE 2014 - 2024

Levando em conta a contribuição dos movimentos sociais na formulação dos Planos de Educação, percebe-se que essa conduta acontece de maneira mais fluída pela maturidade que eles adquiriram, pois participaram de momentos decisivos da história do Brasil, quando se fala em redemocratização, e também tem sua constituição nos anos de 1960 e 1970, a exemplo das Ligas Camponesas e utilização do método Paulo Freire. Nos anos de 1980 a relação dos movimentos sociais e educação se acentuam com a luta pelas Diretas Já. Aos poucos foram sendo construídas redes de movimento social temático e que se 
readaptaram ao contexto democrático. É nesse contexto que se localizam os movimentos sociais e os PNEs.

\subsection{Formulação de políticas públicas e os PNEs}

Nesta seção serão discutidos os conceitos de políticas públicas e de formulação de políticas públicas, sobretudo no que diz respeito às políticas sociais e de educação, com ênfase no ensino superior.

\subsubsection{Conceito de políticas públicas}

O Brasil da década de 1980 e 1990 apresenta problemas de desequilíbrio fiscal, expansão de gastos públicos e, além disso, o setor público apresenta problemas de desempenho a um elevado custo. $\mathrm{O}$ controle e delegação entre formuladores e implementadores de políticas apresentaram, segundo Rezende (2012), poucas mudanças das instituições.

Com a Reforma do Estado em 1995, pretendeu-se diminuir o poder de atuação dele, bem como, sua intervenção na economia e na sociedade. Para o alcance de tal objetivo, reestruturou-se o aparato do Estado, definindo-se quatro áreas de atuação da gestão pública: núcleo estratégico do Estado, as atividades exclusivas do Estado, os serviços não exclusivos do Estado e a produção de bens ou serviços para o mercado (PAULA, 2005).

Com as transformações sociais, políticas e econômicas, as organizações perceberam que necessitavam se posicionar mais estrategicamente, diminuindo o seu viés planejador. Os governos perceberam essas mudanças e só reagiram a elas bem mais tarde. Esse fato implicou descrédito da população nos serviços prestados e, com isso, retardo na capacidade de resposta do Estado às demandas sociais (SARAVIA, 2006). Como consequência, a sociedade sentiu a necessidade de participar do processo decisório, reivindicando um posicionamento mais efetivo do Estado em áreas cruciais como educação e saúde, bem como exigiu maior transparência e provisão de informação em áreas de ação governamental (SARAVIA, 2006).

Essa transposição de um Estado planejador para um Estado estratégico propicia um novo momento de análise das ações do Estado, pois ele se volta à perspectiva da política pública. A partir dessa dinâmica, define-se política pública como um fluxo de decisões que 
objetiva manter ou introduzir o equilíbrio social ou produzir desequilíbrios a fim de modificar realidades (idem).

As decisões tomadas são condicionadas pelas visões, ideias e valores daqueles que as tomam, assim como, dos efeitos que elas provocam na sociedade. Pode-se dizer que as decisões são resultados de estratégias desenhadas para alcançar determinados fins almejados pela sociedade ou por grupos que participam do processo decisório. E é essa finalidade que orienta as ações constituintes das políticas públicas, sejam elas a consolidação democrática, justiça social, manutenção do poder ou outra qualquer. Em outras palavras, consoante Saravia (2006, p. 29), pode-se afirmar que as ações políticas são:

um sistema de decisões públicas que visa a ações e omissões, preventivas ou corretivas, destinadas a manter ou modificar a realidade de um ou vários setores da vida social, por meio da definição dos objetivos e estratégias de atuação e da alocação dos recursos necessários para atingir os objetivos estabelecidos.

Ao longo do processo decisório, percebem-se conflitos de interesses dos grupos ali representados e os arranjos que vão sendo feitos para se estabelecer na arena decisória. Fatores culturais, históricos e econômicos é que definem a maneira como tais arranjos serão feitos. A relação estabelecida entre Estado e sociedade é constantemente permeada por esses elementos e são eles que determinam o grau de estreitamento e distanciamento da sociedade com o Estado. Tal aspecto é importante para determinar o sucesso ou fracasso de uma política pública (HOFLING, 2001).

Por outro lado, há autores que consideram que políticas públicas podem ser conceituadas por aquilo que o governo escolhe fazer ou não. Sendo assim, o não agir também define o que é política pública (DYE, 2014). De fato, quando se decide pelo não agir ainda assim se consegue descrever e explicar as causas e consequências das decisões e atividades do governo.

O estudo de políticas públicas pode, portanto, averiguar e analisar as ações e inações do governo, identificando os impactos sociais, econômicos e políticos. Essa é uma visão mais americana de políticas públicas (DYE, 2014). Isto quer dizer que a associação filosófica e de extensas explicações do que seria a relação entre Estado, governo e políticas públicas é substituída pela explicação do que de fato é políticas públicas e suas consequências. É uma análise que parte da prática para o abstrato, enquanto que a abordagem europeia estuda o conceito e só então ele é contrastado com o mundo empírico.

Feita esta ponderação, políticas públicas são programas de ação governamental para coordenar os meios à disposição do Estado e as atividades privadas a fim de realizar 
objetivos socialmente relevantes. Esse é um conceito que abrange a fiscalização e coordenação dos agentes públicos e privados para o efetivo cumprimento dos direitos sociais (BUCCI, 1997).

Nesse espectro, segundo Saravia (2006) há quatro definições que permeiam as políticas públicas: o institucional; o decisório; o comportamental e o causal. No institucional, a política é elaborada por autoridade formal. Enquanto o decisório representa uma sequência de decisões de curto ou longo alcance para solucionar problemas. Já o comportamental consiste na ação ou inação, sendo a política uma decisão singular. E, por fim, a causal que representa o conjunto de ações que refletem no sistema político e social.

No que esses conceitos convergem é que o desenho da política pública depende de cada sociedade específica e dos arranjos que os grupos do processo decisório desenham. É o grau de maturidade de cada sociedade que define como serão processadas as políticas públicas e quão transparentes serão os processos e o quão eficazes serão as políticas (SARAVIA, 2006).

Em se tratando do processo pelo qual passa uma política pública, pode-se delinear três aspectos que, segundo Saravia (2006), no caso da América Latina podem se subdividir em cinco. São eles: formulação, implementação e avaliação. A formulação pode ser desmembrada em elaboração e formulação. Sendo que a primeira é a preparação da decisão política, já a formulação é a própria decisão formalizada por meio de normas jurídicas. A implementação também pode ser subdividida em elaboração de planos, programas e projetos, que é a preparação para a execução, e, por fim, a execução que consiste na prática propriamente dita da política (SARAVIA, 2006).

A despeito da limitação do modelo racional, e como forma de explicitar didaticamente as etapas do processo, seguem as explanações: a) formação de agenda: momento que se inclui ou não necessidades e questões apresentados pela sociedade ou pelo poder público. Esse é o momento em que uma questão se torna um problema; b) elaboração é e etapa de identificação e delimitação do problema. Ali são também traçadas possíveis soluções para os problemas; c) formulação: é a seleção da alternativa mais adequada para atender àquela demanda. É nesse momento que se definem os marcos jurídicos e quais objetivos são traçados; d) implementação: planejamento e organização do aparelho administrativo e dos recursos humanos, financeiros, materiais e tecnológicos para executar uma política. É a preparação para executar uma política; e) execução: são as ações para alcançar os objetivos almejados; f) acompanhamento: supervisão de atividades com o objetivo 
de fornecer informações para corrigir rotas caso seja necessário e g) avaliação: mensuração e análise a posteriori dos efeitos produzidos na sociedade pelas políticas (idem).

Na prática, o processo decisório pelo qual passam as políticas públicas apresenta complexidades que ultrapassa a descrição teórica feita acima. Um exemplo disso é que a tramitação de uma política não é linear. Ela pode apresentar loops causados por impasses imprevistos ou se esbarra na limitada capacidade analítica da organização. Um outro aspecto relevante diz respeito à comunicação externa adotada no processo de política. Pensa-se que a classe política possui um papel mais ativo na elaboração de uma política (na fase de autorização). Todavia, ainda antes, no momento de formação percebe-se o estabelecimento de outros padrões de comunicação. Por vezes, setores externos à organização governamental são chamados a discutir sobre questões definidoras do processo decisório (MONTEIRO, 2006).

A elaboração e a formulação são caracterizadas por maior fragilidade no processo de políticas públicas e por isso mesmo necessitam estabelecer vínculos com os diversos grupos presentes na sociedade. Com base nas demandas apresentadas e nos interesses ali expostos, a influência exercida por eles impacta nas discussões políticas (LOBATO, 2006).

Os vínculos estabelecidos com a sociedade, segundo Lobato (2006), serão relevantes para o momento da implementação e execução, pois transpõem os anseios dos grupos de interesse para o planejamento e execução das políticas. Como decorrência disso, são definidos quais recursos serão usados e como serão usados para executar os planos elaborados (idem).

Nas fases de implementação e execução deve-se levar em conta as suas estreitas relações com a fase de formulação, sem dissociá-las e tomá-las como fases que não se comunicam. Há, portanto, que se atentar para o fato de que nesse momento uma rede complexa de interações intra-organizacionais se estabelece, influenciando a negociação entre os atores autônomos. Essa autonomia suscita discussões sobre a legitimidade dos interesses dos grupos (HILL, 2006).

O acompanhamento analisa as vicissitudes do processo de formulação e implementação mediante a supervisão da execução. Por outro lado, a avaliação analisa os efeitos das políticas públicas na sociedade (SARAIVA, 2006).

A presença do Estado como formador da sociedade brasileira implica considerar na análise de políticas públicas aspectos da representação de interesses. Para Lobato (2006, p. 299):

No Brasil, a presença absoluta do Estado sobre a sociedade importou no direcionamento de todas as demandas ao seu interior. No entanto, o processo de 
transição democrática demonstrou uma inabilidade desse mesmo Estado em conviver com demandas advindas de formas diferenciadas daquelas tradicionais que surgiram da dinâmica societária, determinando formas plurais de representação de interesses, assim como diferenciações nos padrões então existentes. Os movimentos populares, a criação de partidos de base e a exclusão, mesmo que espasmídica, do Estado nas negociações entre capital e trabalho, são, ao nosso ver, exemplares nesse sentido.

Isso demonstra que com a redemocratização, as bases de negociação do regime burocrático-autoritário não se ampliaram apesar da suposta abertura dos canais de democratização. Isso levou a um processo de institucionalização das representações que não tinham demandas atendidas pelo Estado. Nessa perspectiva, o Estado atua como representante dos grupos dominantes e não de interesses advindos da sociedade (LOBATO, 2006).

As demandas são materializações dos interesses dos grupos diversos. Para atendêlas, o Estado se utiliza da política, mostrando, assim, que elas não conseguem ser totalmente ignoradas. Nesse ponto, a intervenção se faz presente e o Estado inicia o processo de negociação. Quanto mais interesses envolvidos e mais divergentes forem, mais frágil será o momento do Estado. Por conseguinte, a relevância de se relacionar com diversos setores se dá, sobretudo, pela necessidade de difundir interesses ou aquietar aqueles contrários. Deve-se, contudo, considerar que para as demandas ganharem o status público, não depende somente da repressão ou cooptação pelo Estado dos grupos, mas também é preciso que os atores sociais desenvolvam capacidade de conquistar espaços (LOBATO, 2006).

O entendimento de como se constitui uma política pública e seu processo decisório é relevante para compreender como se dá a formulação das políticas sociais, pois estas se desenham conforme se entrelaçam as relações políticas. As políticas sociais são a expressão de intervenção estatal para o fornecimento de bens sociais ou nas palavras de ABRANCHES et al (1998, p. 10), “a política social é parte do processo estatal de alocação e distribuição de valores". Ela está no centro do confronto de interesses de grupos e classes, refletindo a direção política das relações econômicas. A política social equilibra a distribuição de recursos na sociedade por meio de intervenções estatais que a depender da necessidade promove mudanças setoriais ou estruturais.

Nessa perspectiva insere-se a política de educação que também é definida pelos conflitos que a permeiam dos diversos grupos e com interesses diversos. Sendo assim, a política educacional é constituída pelo Estado e não se baseia na boa vontade dele. Ela depende da articulação entre Estado e sociedade e está fortemente ligada ao contexto de Reforma do Estado e globalização (DEITOS, 2010). 
Sobre este último ponto, Abrúcio (1998) afirma que um dos principais objetivos da reforma do Estado é justamente a reforma de políticas sociais, sobretudo, educação e saúde, além, é claro, da redução de gastos e modernização da burocracia. Ele continua dizendo que para que haja mudanças das políticas educacionais, é necessário reestruturação das relações intergovernamentais e da constituição de um sistema cooperativo e coordenado.

A política educacional irá sofrer todas as consequências da Reforma do Estado implementada em 1995 e nas seções seguintes serão apresentadas as articulações feitas entre os diversos segmentos da educação na arena de negociação. Ao fim, se verá como nascem as políticas públicas educacionais a partir desses conflitos.

\subsubsection{Formulação de Políticas Públicas}

A formulação de políticas públicas responde aos questionamentos "quem decide o quê, quando, com que consequências e para quem. São definições relacionadas com a natureza do regime político em que se vive, com o grau de organização da sociedade civil e com a cultura política vigente" (TEIXEIRA, 2002, p. 2).

Entende-se por formulação de políticas públicas, segundo Souza (2006, p. 26), um “estágio em que os governos democráticos traduzem seus propósitos e plataformas eleitorais em programas e ações que produzirão resultados ou mudanças no mundo real”.

Considera-se, assim, esse momento de formulação como sendo um processo de negociação, de troca e de concessão. Por isso mesmo, ele pode ser lento ou mais célere a depender da agilidade e do poder de barganha entre os negociadores dos diversos grupos. Essa negociação se dá mediante troca de voto, troca de favores e apoio político para ações futuras. Além disso, é o grau de cumprimento desses acordos ou promessas que definem se os atores políticos se engajam ou não em determinadas ações. Todo esse processo também é formatado pelos atores políticos envolvidos e pelo ambiente institucional em que se inserem (TEIXEIRA, 2002).

Nesse sentido, a formulação enquanto a construção do status público ou do interesse público depende das relações que se estabelecem entre a sociedade civil e os atores políticos. Portanto, é um processo complexo e que varia de caso em caso. As nuances desse momento da política pública só são captadas pelo estudo empírico das políticas (HOWLETT;1995).

Para estes mesmo autores (TEIXEIRA, 2002; HOWLETT, 1995), a formulação não necessita ser um processo de um grupo só. Ela pode e deve ser feita por diversos grupos 
de forma competitiva ou complementar. Assim, várias propostas surgem para enriquecer a discussão dos problemas detectados. Outra característica consiste no fato de que os formuladores não são necessariamente obrigados a saber do problema em si em sua totalidade. A clara definição das questões que aparecem nem sempre são necessárias para a formulação do problema.

Ademais, os formuladores podem nunca chegar a uma proposta que acabe com todas as causas do problema e agrade a todos os grupos. E ainda inserida nessa lógica, a formulação mostra que sempre alguém ganha e alguém perde. É um processo isento de pontos neutros. Há disputas e alguns grupos se sobreporão a outros (TEIXEIRA, 2002).

Segundo Howlett (1995), a formulação de políticas envolve a eliminação de algumas opções até que fique aquela pela qual o formulador se interesse e selecione. Sendo assim, os policy makers reconhecem suas limitações. Para melhor ilustrar esse fato, o autor coloca que políticos, por exemplo, ou decidem por política que tenham um apelo eleitoral grande ou por aquelas que refletem um bem-estar econômico. Sendo assim, os políticos não conseguem fazer as duas coisas. É uma ou outra proposta (HOWLETT, 1995).

Para Deitos (2010), a formulação e a implementação de políticas sociais e educacionais são formatadas de acordo com as relações e forças sociais em disputa. Essas políticas têm passado por um processo de descentralização na gestão o que intensifica o poder local e necessidade de novos arranjos institucionais que atuem nas mais diversas áreas de uma problemática. A participação social passa a ser vista como uma peça fundamental para a formulação de políticas sociais e educacionais

Como esse é um momento em que a discussão de ideias e propostas se faz presente, o conceito trazido por Habermas de democracia deliberativa contribui para que esse momento seja plural e inclusivo. A ação comunicativa, desenhada pelo autor, deve estar presente, sendo os procedimentos que envolvem a formulação argumentativos, inclusivos e públicos, além disso, não se deve sofrer coação externa e, internamente deve possuir igual chance de contribuição, possibilidade de rever opiniões e abertura para contribuições diversas (HABERMAS, 2003).

Para Habermas (2003), é necessário desconcentrar a tomada de decisões, no que diz respeito ao interesse público, das mãos de um único agente. A pluralidade é vital para o processo decisório e quanto mais grupos e agentes envolvidos tanto melhor o resultado. Nessa perspectiva, a identidade coletiva dos atores sociais são consequências diretas das iniciativas de proposição. 
Contudo, à pluralidade de atores é inerente diversidade de interesses e por consequência conflitos. Para Teixeira (2002), na sociedade civil a diversidade de interesses e visões também precisa ser trabalhada, confrontada e negociada a fim de chegar a um consenso mínimo. Ele acrescenta que um elemento que coopera com a complexidade do sistema de formulação é a fragmentação das organizações. Essa fragmentação dificulta sobremaneira o processo de articulação e cooperação anteriormente explanado.

Para amenizar essa barreira encontrada pela formulação e para tornar a participação da sociedade civil mais efetiva e eficaz, é necessário observar alguns momentos e acompanhá-los de perto. São eles: a) Elaboração e formulação de um diagnóstico participativo e estratégico com os principais atores envolvidos, no qual se possa identificar os obstáculos ao desenvolvimento, fatores restritivos, oportunidades e potencialidades; negociação entre os diferentes atores; b) Identificação de experiências bem sucedidas nos vários campos, sua sistematização e análise de custos e resultados, tendo em vista possibilidades de ampliação de escalas e criação de novas alternativas; c) Debate público e mobilização da sociedade civil em torno das alternativas mais entre os atores; d) Decisão e definição em torno de alternativas; competências das diversas esferas públicas envolvidas, dos recursos e estratégias de implementação, cronogramas, parâmetros de avaliação; e) Detalhamento de modelos e projetos, diretrizes e estratégias; identificação das fontes de recursos; orçamento; mobilização dos meios disponíveis e a providenciar; mapeamento de possíveis parcerias, para a implementação; f) Na execução, publicização, mobilização e definição de papéis dos atores, suas responsabilidades e atribuições, acionamento dos instrumentos e meios de articulação; g) $\mathrm{Na}$ avaliação, acompanhamento do processo e resultados conforme indicadores; redefinição das ações e projetos (TEIXEIRA, 2002, p. 6).

Ainda, consoante Teixeira (2002), o jogo político que existe na arena de formulação no ambiente democrático exige distribuição e redistribuição do poder. Entretanto, somente isso não conduziria a mudanças substanciais de conteúdos e de metodologias de políticas públicas. Para que haja tal mudança, seria necessário alternância na composição do poder e debate público de alternativas que não contemplem somente críticas, mas sugestões cabíveis de resolução de problemas. Para isso, seriam ainda, necessárias proposições legitimadas que abranjam interesses coletivos e não somente interesses corporativos ou setoriais.

À vista do exposto, a sociedade civil está cada vez mais articulada em organizações representativas em espaços públicos e propõe cada vez mais alternativas nos 
vários campos de atuação do Estado coparticipando da sua formulação, implementação e gestão (TEIXEIRA, 2002).

Na próxima subseção será debatido o processo de atuação da sociedade civil na formulação de políticas de educação de ensino superior na elaboração do PNE. Sob a ótica do paradigma democrático, analisar-se-á o processo de formação de políticas que deixou de ser exclusivo de especialistas e passou a envolver outros segmentos sociais para se pronunciar e definir diretrizes e prioridades.

\subsubsection{Sociedade Civil e Políticas Públicas}

Essa seção objetiva discutir a relação entre Estado e sociedade e o sistema democrático e políticas públicas. Ham e Hill (1993) definiram quatro campos teóricos de análise desse estudo: pluralista, elitista, corporativista e marxista. A primeira teoria concerne às ideias liberais clássicas sobre o envolvimento do cidadão no alcance de um Estado democrático. Entende-se que não há uma distribuição homogênea de poder, mas que é importante que exista diversidade de grupos. Isto por que o equilíbrio entre forças opostas é garantia de uma sociedade livre sob a ótica econômica e de políticas públicas (LOBATO, 2006).

O Elitismo afirma que há concentração de poder nas mãos de uma minoria, opondo-se ao descrito pela Pluralista. Para Ham e Hill (1993), a teoria elitista afirma que os grupos de elites são necessários à sociedade e se subdividem em elite política, que é aquela que exerce historicamente o poder de fato, e a classe política cuja elite política associa-se a outras elites. Nessa teoria específica, entende-se que o controle de determinados grupos sobre as discussões limitam os debates acerca de temas mais difíceis. Isso pode justificar porque temas acerca do financiamento da educação de nível superior geram maior tensão.

Já o corporativismo reconhece o conflito como intrínseco às relações políticas e sociais e os grupos são reconhecidos e criados pelo Estado o que garante o monopólio dentro de suas categorias (LOBATO, 2006). O que diferencia os corporativistas dos marxistas é que para o primeiro grupo os conflitos podem ser superados. Por outro lado, os marxistas apontam que a origem dos conflitos políticos é a luta de classes e que prevalece a concentração de poder numa classe específica. Além disso, o poder econômico está diretamente ligado ao poder político tendo o Estado como elemento de sustentação do poder de classes (HAM; HILL, 1993). 
Entende-se que as características desses modelos podem ser encontradas em todas as sociedades e, portanto, não se pode se apropriar de um único modelo para explicar a relação entre Estado e sociedade (HAM; HILL, 1993) e (LOBATO, 2006). Dessa forma, para Lobato (2006) é mais importante verificar as relações entre Estado e os grupos de interesse, pois a autora considera que é o status público que o Estado concede a um ou outro desses grupos que influencia na capacidade de formulação de políticas, do que enquadrar essa relação em um ou outro modelo.

Lobato (2006) acredita que diante de um cenário onde o processo de democratização é recente, o Brasil encontra dificuldade em conviver com as demandas da sociedade. Isso dificulta o estudo da relação entre Estado e sociedade e implica um processo de externalização das demanadas da sociedade, ou seja, elas surgem a partir da negação do Estado em atendê-las ou pela cooptação de atores da sociedade. Portanto, as demandas sociais têm espaço na agenda de acordo com as relações de interesses (LOBATO, 2006).

A participação dos movimentos sociais no Brasil aconteceu mais intensamente a partir dos anos 1980 quando o Estado se caracterizava por ser clientelista, corporativista e era marcado pelo insulamento burocrático. As políticas públicas, por sua vez, eram marcadas pela fragmentação institucional e desarticulação entre as áreas (FARAH, 2001).

Ainda segundo Farah (2001), a sociedade civil não era considerada no processo decisório já que havia um modelo de relação entre sociedade e Estado não democrático que excluía uma boa parte da população do acesso a bens e serviços. O Estado priorizava o tratamento do déficit fiscal e a questão da responsabilidade pública em detrimento da participação social. Ademais, a gestão era burocratizada, ineficiente e não tinha um relacionamento estreito entre o cidadão e os agentes públicos.

Esse cenário da década de 1980 e 1990 introduziu na agenda política os conceitos da eficiência, eficácia e efetividade da atuação do Estado. Com isso o ideário neoliberal foi incorporado na agenda das políticas públicas e, consequentemente, na da política social. Visando atender a essa nova configuração do Estado foi promovida uma Reforma Estatal. Buscaram-se novas formas de se relacionar tanto com a sociedade civil quanto com a iniciativa privada (FARAH, 2001).

O Estado passa a ocupar um papel fiscalizador e orientador enquanto que as políticas são executadas pela sociedade civil em conjunto com o mercado. Há, portanto, uma redistribuição de poder e a ideia de gestão passa a considerar a equidade e democratização dos processos decisórios ao conceito de eficácia e eficiência. Consoante Perez (2009) essa redefinição do papel exercido pela sociedade civil promove mudanças na forma de agir da 
Administração Pública com os administrados, os agentes públicos e também com a estrutura hierárquica.

A redefinição da agenda de políticas sociais se redefine conforme esse novo cenário se transforma. Ela passa a se embasar pelos seguintes pressupostos: articulação da agenda social e econômica, integração de programas sociais seletivos e universais, integração da política social ao plano de desenvolvimento, a consolidação de um sistema de proteção social e, por fim, a racionalização do gasto social. As políticas sociais passam a ser definidas pelas ações articuladas entre diversos atores, incluindo os movimentos sociais com o governo, na formulação, implementação e acompanhamento (FARAH, 2001).

Tem-se com isso a construção da democracia participativa cuja abertura da participação social no processo decisório redefine a forma de gestão e influencia diretamente no formulação e implementação de políticas e também na relação entre Estado e sociedade. A Constituição Federal de 1988 estabelece em diversos artigos princípios relacionados à democracia participativa ainda que não concretos e explícitos que orientam na conduta da sociedade e do Estado. (PEREZ, 2009).

A participação social na gestão de políticas contribui para se estabelecer a democracia e o Estado de Direito. Dessa forma, os institutos de participação social objetivam a realização dos direitos políticos viabilizando a cidadania social. Para efetivar a participação social deve-se organizar o poder em institutos construídos coletivamente para se deliberar sobre as políticas públicas. Os institutos de participação social se fundamentam na ideia de que o processo decisório deve ocorrer mediante participação e deliberação em espaços de marcados por debates e negociação (FARIA, 2006).

Por outro lado há autores que acreditam como o Wendhausen (2006) que estes espaços de participação social podem também se subordinar à gestão, desvirtuando-se de seus objetivos. Nesses casos a ideia de participação do cidadão na formulação e implementação de

políticas são suplantadas por interesses de determinados grupos que dificultam os debates e negociação, utilizando-se de práticas clientelistas, de manipulação e de troca de favores.

\subsubsection{Políticas Públicas do Ensino Superior}

Os movimentos de Educação Superior, como visto em seções anteriores, sempre tiveram papel fundamental na formulação de políticas de educação enquanto instância da sociedade civil. Com a redemocratização, de um lado estavam aqueles grupos que defendiam um ensino público gratuito em todos os níveis e, do outro estavam aqueles ligados ao setor 
privado interessados em obter verbas públicas e diminuir a interferência do Estado em instâncias privadas.

Nesse contexto, a Constituição Federal estabelece em seu artigo 207 a indissolubilidade das atividades de ensino, pesquisa e extensão. Para tal cumprimento prevê a destinação de $18 \%$ da receita anual resultante de impostos da União para a manutenção e desenvolvimento do ensino.

Mais tarde, com a instituição da LDB foi previsto graus de abrangências ou especialização nos estabelecimentos de ensino superior. Além disso, ela também prevê processos regulares de avaliação dos cursos de graduação e das próprias instituições de educação superior, condicionando seus credenciamentos ao desempenho mensurado por essa avaliação.

A estrutura da educação superior no Brasil possui um sistema complexo e diversificado de instituições públicas e privadas com diferentes níveis de ensino e com diferentes tipos de cursos e programas. Essa estrutura encontra-se formalizada na Constituição e na LDBN/96 e mais um conjunto de Decretos e Portarias. Entretanto, essa estrutura é ainda baseada na Lei $n^{\circ}$ 5.540/68 decorrente da Reforma Universitária. A seguir expõe-se alguns dispositivos importantes que foram implementados (BRASIL, 2013, p. 41):

a) a organização das universidades passou a atender às seguintes características: extinção do antigo sistema de cátedras e introdução da estrutura fundada em departamentos; unidade de patrimônio e administração; estrutura orgânica com base em departamentos reunidos ou não em unidades mais amplas; unidade de funções de ensino e pesquisa, vedada a duplicação de meios para fins idênticos ou equivalentes e estabelecida a racionalidade de organização, com plena utilização dos recursos materiais e humanos; universalidade de campo, pelo cultivo das áreas fundamentais dos conhecimentos humanos; flexibilidade de métodos e critérios, com vistas às diferenças individuais dos alunos, às peculiaridades regionais e às possibilidades de combinação dos conhecimentos para novos cursos e programas de pesquisa.

b) o departamento passou a constituir-se na menor fração da estrutura universitária para todos os efeitos de organização administrativa, didáticocientífica e de distribuição de pessoal, devendo englobar as disciplinas afins. Os cargos e funções de magistério, mesmo os já criados ou providos, devem ser desvinculados de campos específicos de conhecimentos.

c) a introdução da matrícula semestral por disciplinas e do sistema de créditos. 
d) a institucionalização da pós-graduação stricto sensu, por meio dos cursos de mestrado e doutorado no país.

e) a instituição do vestibular unificado e classificatório, como forma de racionalizar a oferta de vagas

A reforma universitária determinava que o ensino superior deveria ser vivenciado em universidades e, excepcionalmente, em estabelecimentos isolados, organizados como instituições de direito público ou privado. Contudo, a partir da década de 1970 se deu a expansão do sistema de ensino superior, em função do aumento do número de instituições privadas e estabelecimentos isolados. Além disso, a autonomia financeira e de gestão de pessoal preconizada pela Reforma ainda não existe (BRASIL, 2013).

Desde a Reforma, a principal mudança que aconteceu nos órgãos ligados a educação foi a incorporação de representantes da comunidade acadêmica como exemplo disso tem-se o Conselho Nacional de Educação - CNE. O controle normativo do MEC é feito pela Secretaria de Ensino Superior.

O CNE foi instituído pela Lei $n^{\circ} 9.131 / 95$, sendo composto por duas câmaras representativas: a de Ensino Básico e Ensino Superior. No que se refere ao Ensino Superior, a câmara é composta por metade de conselheiros indicados a partir de indicações de entidades nacionais, públicas e privadas (reitores de universidades, diretores de instituições, docentes, estudantes, segmentos da sociedade civil). Os outros conselheiros são indicados pelo Presidente da República incluindo o Secretário de Ensino Superior (BRASIL, 2013).

A competência da câmara de caráter deliberativo e assessoramento do MEC é analisar e emitir pareceres sobre o processo de avaliação, deliberar sobre o reconhecimento de cursos de graduação mestrado e doutorado, assim como o credenciamento/recredenciamento de IES; analisar questões relativas à aplicação da legislação referente à educação superior; deliberar sobre as diretrizes curriculares propostas pelo MEC para os cursos de graduação; oferecer sugestões para a elaboração do Plano Nacional de Educação e acompanhar sua execução; e deliberar sobre os estatutos das universidades e o regimento das demais instituições (idem, ibid).

Além do controle normativo, a SESU subsidia o processo de formulação e implementação da Política Nacional para o ensino superior. Além disso, participa da elaboração de programas e projetos voltados à reforma do sistema federal de ensino, zela pelo cumprimento da legislação educacional no âmbito da educação superior, apoia técnica e financeiramente as IFES e elabora e dissemina estudos sobre a educação superior e sua relação com a sociedade (idem, ibid). 
Somando-se a essas instituições que representam o governo e instituições privadas na formulação de políticas de ensino superior, há também os organismos não-governamentais. Com a diversificação institucional do sistema de educação superior, outros atores políticos surgiram, havendo uma fragmentação e reorganização de seus órgãos representativos.

De acordo com Sampaio (2000), a natureza e composição dos associados possuem duas formas básicas de organização: enquanto as organizações que representam uma única categoria (pública ou privada) têm, como objetivo, reforçar a sua identidade e os seus interesses específicos, enquanto que as outras (integradas por representantes de ambas categorias) buscam construir estratégias e planos de ação que atendam aos interesses gerais dos seus associados. Os principais organismos são: CRUB - Conselho de Reitores das Universidades Brasileiras, ABMES - Associação Brasileira de Mantenedoras de Instituições Superiores, ABRUC - Associação Brasileira das Universidades Comunitárias, ANDIFES Associação Nacional dos Dirigentes das Instituições Federais de Ensino Superior, ANUP Associação Nacional das Universidades Privadas, ANACEU - Associação Nacional dos Centros Universitários e Conselhos Profissionais Federais.

Em se tratando das políticas de ensino superior e voltando-se para a proposta desse trabalho que abrange apenas o período de elaboração dos Planos Nacionais de Educação, as políticas educacionais do período do governo FHC, segundo Cunha (2003), se resumem à criação do ENEM, criação de conjunto de leis que regulam mecanismos de avaliação, ampliação do poder docente na gestão universitária e reconfiguração do Conselho Nacional de Educação. Por outro lado, no governo de Luis Inácio Lula da Silva, que precedeu e acompanhou a formação do PNE II (PNE 2014 - 2024), teve como medidas a edição do Decreto de 20 de outubro de 2003 que institui o Grupo de Trabalho Interministerial para analisar a situação atual e apresentar plano de ação visando a reestruturação, desenvolvimento e democratização das Instituições Federais de Ensino Superior - IFES.

Ainda nesse mesmo ano ocorreram duas outras iniciativas importantes em relação ao ensino superior. Em agosto, a Secretaria de Ensino Superior do Ministério da Educação (SESU/MEC) organizou o Seminário "Universidade: por que e como reformar" para apresentar às Comissões de Educação do Senado e às da Câmara dos Deputados. Em novembro, o MEC, com o apoio da UNESCO, do Banco Mundial e da ONG internacional ORUS (Observatoire International des Réformes Universitaires) realizou o Seminário Internacional "Universidade XXI: novos caminhos para o ensino superior". Nesses dois eventos, diversos temas foram debatidos para a redefinição de uma agenda para o ensino 
superior. Dessas discussões nasceu um relatório que apontava a necessidade de formulação e implantação de uma reforma universitária brasileira (SAMPAIO, 2000).

Dentro do escopo desse trabalho, serão apresentados programas que atendem especificamente políticas que objetivam ampliar o acesso ao nível superior. É válido enfatizar que das discussões do GT foram extraídos importantes pontos que foram acrescentados em reuniões da Conae para formulação do PNE II (PNE 2014 - 2024). Diferente do PNE I (PNE 2001 - 2010) que as ações se concentraram nas mãos do governo. Os programas são os seguintes:

a) Programas/ações de diversificação acadêmica e de articulação do ensino, pesquisa e extensão: Programa de Educação Tutorial - PET e Programa de Apoio à Extensão Universitária (PROEXT);

b) Programas/ações de avaliação e de regulação do sistema: Sistema de Credenciamento e Recredenciamento de IES;

c) Programas/ações de cooperação e relações internacionais: Certificado de proficiência em Língua Portuguesa para Estrangeiros, Programas de Estudantes Convênio de Graduação, Programa Milton Santos de Acesso ao Ensino Superior e outros;

d) Programas/ações de articulação da educação superior com a educação básica: Programa de Consolidação das Licenciaturas (Procedência);

e) Programas/ações de acesso e permanência: Programa de Financiamento ao Estudante do Ensino Superior, Exame Nacional do Ensino Médio O Programa de Apoio a Planos de Reestruturação e Expansão das Universidades Federais (Reuni) entre outros.

Esses são os programas formulados no período de discussão e debates sobre o PNE II. Eles se caracterizam, sobretudo, por atender as demandas por ampliação de acesso ao ensino superior, mas são cuidadosos com a racionalização dos recursos, conforme afirma Mancebo (2004).

A análise dos Planos Nacionais de Educação precisa considerar tanto a formação de agenda e como o processo decisório. Ao analisar o fluxo dos Planos, percebe-se que o contexto em que as questões foram postas naqueles documentos advém das discussões que a todo momento a imprensa instiga ou por indicadores que são apresentados seja do próprio governo, seja de institutos independentes, a exemplo das divulgações de dados sobre ensino superior realizadas pelo INEP. 
Dentro do modelo Multiple Streams desenvolvido por John Kingdom, ele preleciona que uma questão só passa a fazer parte da agenda quando desperta a atenção e o interesse de formuladores de políticas. Considerando a complexidade e diversidade de assuntos somados ao grande volume de decisões, as questões tornam-se problemas quando os formuladores de políticas percebem que devem fazer algo. E, por sua vez, a percepção dos formuladores depende da forma como as questões são percebidas como problemas por meio de três mecanismos: indicadores, eventos ou crises e feedback sobre programas em desenvolvimento (CAPELLA, 1996).

Observou-se nos encontros que antecederam à formulação dos documentos dos Planos que as questões levantadas advêm do acompanhamento das atividades de implementação, o cumprimento (ou não) de metas e, sobretudo, de possíveis reclamações de servidores ou dos cidadãos. Situações essas que foram determinadas no modelo de Multiple Streams (CAPELLA, 1996). Ademais, além do primeiro fluxo que é a definição de um problema, é importante a conversão dos dois outros fluxos que são soluções e alternativas (policies) e a política (politics).

Nesse modelo, o fluxo de soluções apresenta alternativas que se encaixam nos problemas. Geralmente, são ideias viáveis tecnicamente. Quando isso acontece, a ideia é difundida tornando-se conhecida em vários segmentos sociais, o que não significa que é aceita prontamente por todos. Há setores que possuem suas opiniões e não se submetem às novas percepções. Para Capella (1996, p. 28):

a difusão é como um processo no qual indivíduos que defendem uma ideia procuram
levá-la a diferentes fóruns, na tentativa de sensibilizar não apenas as comunidades de
políticas (policy communities), mas também o público em geral, vinculando a
audiência às propostas e construindo progressivamente sua aceitação. Dessa forma,
as ideias são difundidas, basicamente, por meio da persuasão. A importância desse
processo de difusão - chamada de soften up pelo autor - vem da constatação de que,
sem essa sensibilização, as propostas não serão seriamente consideradas quando
apresentadas.

Isso mostra que os debates ocorridos nos fóruns e conferências são representativos no que se refere à construção e aceitação de ideias. Daí a importância de agregar divergentes setores da sociedade. Por fim, tem-se o fluxo político que apresenta suas próprias regras e também é onde as coalizões são construídas. Nesse fluxo existem alguns fatores que influenciam na agenda governamental, mas para esse trabalho o que interessa é o elemento caracterizado pelas forças políticas organizadas principalmente pelos grupos de pressão. Em outras palavras, quando todos estão de acordo com a proposta, a mudança acontece. Caso 
contrário, o conflito se estabelece, demandando outras manobras e mais esforço de convencimento para que aquela ideia entre na agenda (CAPELLA, 1996).

Exemplo disso é que questões como erradicação do analfabetismo e melhoria na qualidade da educação são assuntos pacificados, já questões que envolvem financiamento da educação se mostram mais delicadas, pois setores divergentes tendem a brigar por recursos.

Nas seções anteriores, viu-se que o processo pelo qual passaram os Planos caracterizou-se pelo debate sobre o sistema educacional encabeçado pelo Coned e pela Conae convocada por uma Comissão Nacional composta por representantes do governo federal e por segmentos da sociedade civil, no caso da segunda, e, no caso da primeira, somente por representantes da sociedade civil.

Retomando a discussão sobre o processo decisório, percebe-se que ele não é ordenado e racional. Isso se verifica quando a solução proposta por um grupo não atende a outro. Um exemplo disso foi a mudança no texto do projeto de lei quanto ao financiamento relatado no parágrafo anterior. Um grupo se sobressai e outro não é atendido em sua completude.

Corroborando a esse pensamento, Lindblom (1981. P. 10) afirma que:

\begin{abstract}
Algumas vezes se forma uma política a partir de negociação entre várias partes interessadas, que chegam a um acordo a respeito de problema que não era precisamente o que interessava a cada uma das partes. Outras vezes, como já notamos, as políticas derivam de novas oportunidades, não de problemas propriamente [...]. Concebemos o processo decisório político como algo extremamente complexo, sem princípio nem fim, cujos limites são incertos. De algum modo, um conjunto complexo de forças produz determinados efeitos, que chamamos de "políticas".
\end{abstract}

A forma como os arranjos democráticos são feitos é que definem como as opções se apresentam para os formuladores de políticas. Dessa forma, não há uma relação lógica e direta daquilo que os cidadãos desejam com a política que de fato eles obtêm. A decisão de políticas por parte das autoridades depende das regras, relações de autoridade, procedimentos e organização existente entre os eleitos. Ao fim como os formuladores de política promovem os arranjos conforme sua conveniência, eles acabam por colocar obstáculos ao controle popular e dificultam o processo de inserção da sociedade civil na formulação também de novos planos governamentais.

Nesse momento em que o plano percorreu pelos trâmites da arena parlamentar, o grupo de empresários da educação entrou em cena articulando-se com os parlamentares para melhor atender aos seus interesses, daí emendas importantes ao plano foram feitas. O retorno 
desse texto à câmara dos deputados os levou a novas e intensas discussões sobre as mudanças no teor do projeto que foram feitos na outra casa legislativa.

Dentro do contexto de como se constitui a formação de política no processo decisório, encontra-se o fato de que ela é definida pela sua emergência ao longo desse processo. Em processos de tomada de decisão mais rotineiros, as ações do policy maker são programadas desde o início e no decorrer do processo elas vão sendo dosadas à medida que as conjunturas se estabelecem. Outro aspecto é que as políticas tornam-se conhecidas ou tomam forma ao longo do processo decisório. Aqui, o processo não é simplesmente a operacionalização da política, mas a compreensão do problema de política e suas soluções. É comum adotar, ou melhor dizendo, adaptar políticas anteriormente adotadas (MONTEIRO, 2006).

Dessa forma, o processo pelo qual passa a formulação do PNE se enquadra mais no segundo aspecto, pois desde a discussão do plano até a apresentação dele para o Congresso Nacional, mostrou que os problemas vão se tornando conhecidos e soluções vão surgindo em todo o processo. Isso é bem diferente do caso em que o policy maker é inovador e dele é exigido uma ação nova e diferente do que é praticado.

Para Monteiro (2006), após o reconhecimento e diagnóstico da política, dá-se início à fase de desenvolvimento e determinação. Essa fase consome tempo e recursos humanos e materiais. Buscam-se políticas já disponíveis praticadas em situações semelhantes, agindo de forma mais ativa (setores procuram soluções diretamente) ou mesmo passivamente (aguardam-se propostas e soluções). Ao fim, o que se observa é que tanto se desenvolvem soluções inovadoras para determinado problema específico ou mesmo reutilizam-se soluções já conhecidas e as adaptam aos problemas, conforme diagnóstico feito.

A penúltima fase refere-se à seleção de alternativas que surgiram. Esse passo caracteriza-se por ser mais aleatório. Ela é a fase do peneiramento. Num primeiro momento, eliminam-se políticas não viáveis, como, por exemplo, saem de cena aquelas que não comprometam as possibilidades eleitorais do governo. Nesse ponto, de avaliação ou escolha, as políticas são mais reconhecidas e sujeitas a barganhas políticas.

Por fim, o último passo é o da autorização que nas palavras de Monteiro (2006. p. 278):

Por fim, ocorre a autorização, de vez que nem sempre quem escolhe a política tem autoridade legal para comprometer a organização com esse curso de ação. A tramitação legislativa é, por vezes, a contrapartida formal dessa fase de autorização, que - obviamente - pode ser meramente simbólica ou homologatória. Todavia, não 
deveríamos supor que essa autorização é uma consequência inevitável, ou tão pacífica, das fases anteriores do processo de formação de uma política.

Com a autorização, a política se torna mais transparente para a sociedade como um todo e é nessa circunstância que se poderá perceber melhor os interesses dos diversos grupos atuantes, os critérios decisórios utilizados e os instrumentos de execução da política.

Transportando essa etapa para o caso em estudo, percebe-se que o trâmite do PNE II, diferente do prelecionado por Monteiro (2006), a autorização da política não possuiu um caráter homologatório. Isso se deveu às emendas apresentadas em todo o processo que, em alguns casos, mudou a forma como a política era vista por determinado segmento da população. A questão do financiamento torna-se um exemplo disso, pois a mudança textual proposta redirecionou parte da destinação de recursos que antes estavam todas destinadas ao ensino público para o ensino privado.

No que diz respeito à implementação do PNE, oficialmente intitulado de Lei $\mathrm{n}^{\circ}$ 13.005, de 25 junho de 2014, ainda serão observados os frutos dela. Até o momento não há sinalização de grandes mudanças de rumo dos programas elaborados pelo Ministério da Educação. Pelo histórico do antigo PNE, observou-se que não é dele que deriva o sistema de educação e, com isso, não cabe ao plano articulá-lo. Como ainda há carência de mudanças estruturais no PNE, os programas decorrem das ações que foram apresentadas e das metas estabelecidas. Ainda prevalece um caráter quantitativo nos programas da educação (SAVIANI, 2014).

A implementação desse plano nos próximos dez anos deverá ser acompanhada para melhor analisar as mudanças que ocorrerem ou os entraves e dificuldades que forem encontrados a frente. Isso servirá como base para discutir pontos mais substanciais da educação. O diagnóstico da educação, deficiente para a elaboração do novo PNE, deve ser levado a sério para fundamentar escolhas e posicionamentos.

O envolvimento de diversos setores da educação na construção do novo PNE mostra a capacidade de mobilização dos movimentos sociais organizados. Assim, ao participar das discussões do novo PNE, os setores da área de educação se sentem protagonistas no papel de formulação de políticas públicas.

Entende-se que houve um estreitamento de relações entre o governo, acadêmicos, sindicatos e lideranças de movimentos sociais. Com isso, os discursos já não se diferenciam tanto, ou ao menos, estão mais compreendidos pelos grupos. Isso pode ser visto no texto em que assuntos discutidos na Conae estavam presentes no texto apresentado às casas legislativas (SANTOS, 2010). 
A tramitação do projeto nas casas legislativas já possui outra característica dentro do processo decisório. Nesse momento, as regras do jogo parlamentar, pelo seu próprio objetivo que é o de produzir a lei que deverá ser cumprida, despertam a atuação de grupos de interesse que conseguem influenciar mais estrategicamente nesse momento. Daí, o aparecimento de emendas no texto que atendem a determinados segmentos da sociedade.

O PNE II (PNE 2014 - 2024) contribuiu para aproximar diversos segmentos e dialogar sobre os rumos do ensino nos próximos dez anos. Entretanto, ainda precisa melhorar a sua estruturação formal, como, por exemplo, discutir questões mais substantivas, enxugando as metas e objetivos, fato esse, que dificulta o acompanhamento e controle social (SAVIANI, 2011).

Enfim, o processo pelo qual passou o PNE II - apesar de ter sido marcado por um diagnóstico falho e atender um determinado segmento de trabalhadores da educação, segundo Saviani (2011), quando o assunto é financiamento, pode-se depreender até o atual estágio da pesquisa que foram obtidos avanços referentes à congregação de vários segmentos da educação para discutir educação e ensino. 


\section{MÉTODO}

Neste capítulo será apresentado o método utilizado para a realização desse estudo. A descrição metodológica é relevante, pois é a partir dela que se evidenciam a validade, a confiabilidade e a aplicação da pesquisa. Para tanto, tem-se que os procedimentos metodológicos relacionam-se aos pressupostos teóricos para melhor orientar o entendimento do problema de pesquisa. Dessa forma, a escolha metodológica desse estudo foi feita de forma a preservar a lógica científica a partir da relação estabelecida pelos seguintes componentes: o referencial teórico, a visão da pesquisadora e a coleta e análise dos dados (VIEIRA, 2005).

\subsection{Tipo e Desenho da Pesquisa}

Esta pesquisa caracterizou-se por ser interdisciplinar, longitudinal, aplicada, exploratória, descritiva e qualitativa (FARIAS FILHO, 2013). Em outras palavras, foi interdisciplinar, pois se baseou numa relação de integração entre as partes constituintes de mais de uma disciplina acadêmica. No caso em tela foram abordados assuntos das ciências políticas e educação. Ela foi longitudinal, pois os estudos foram realizados em um período maior de tempo, abrangendo os dois períodos que antecederam a formulação dos PNEs (1996 a 2000 e 2010 a 2012).

O caráter exploratório dessa pesquisa se deve ao fato de que houve um momento que se exigiu uma maior familiaridade com o problema a fim de construir hipóteses e torná-lo explícito. Já o caráter descritivo adveio da necessidade de se descrever as características dos fenômenos, conforme explicitado nos objetivos específicos (GIL, 2010). Sendo assim, nessa pesquisa, essas características se devem pelo fato de que houve a exploração dos documentos, bem como a definição de um plano descritivo, pois essa análise permitiu identificar quais os protagonistas que se envolveram no debate da política de educação superior e quais foram as características da Conferência Nacional de Educação e descrever o contexto institucional no qual ela estava inserida.

Por fim, no delineamento desta pesquisa foi adotada prioritariamente a abordagem qualitativa porque se observou que a interpretação dos fenômenos e a atribuição de significados são básicas no processo desse estudo. Já o método de procedimento foi histórico e comparativo (MARCONI, LAKATOS, 2010). 
Um aspecto importante na pesquisa qualitativa é o uso da teoria. Esse uso pode ser de quatro maneiras: a teoria serve para explicar amplamente o comportamento e atitudes, ou ela serve como uma lente ou perspectiva teórica que orienta o estudo, ou a teoria torna-se o ponto final ou, por fim, quando não se parte de nenhuma teoria explícita (CRESWELL, 2010).

Dentro dessa classificação, o presente estudo usou a teoria para explicar os fenômenos observados. Nesse caso, o pesquisador testou as questões de pesquisa da teoria, sendo que essa serviu como uma explicação direta do fenômeno. Em seguida, baseados nos estudos teóricos, foram elaborados o problema de pesquisa, as hipóteses e os objetivos. Posteriormente, como consequência desses objetivos, foram definidas as categorias. Com isso estruturado, o roteiro de perguntas foi desenvolvido e aplicado aos atores identificados nas informações extraídas dos documentos.

Isso quer dizer que a partir da análise de em que medida houve participação social na formulação do Plano Nacional de Educação II em relação à construção das metas para a educação de nível superior se deu a investigação por meio do estudo da atuação dos movimentos de participação social da educação nas deliberações da Conae quando da formulação das políticas de nível superior.

Nesse sentido, as deliberações da Conae foram analisadas à luz das informações obtidas pelas entrevistas sendo comparados os discursos proferidos pelos entrevistados ao texto que de fato foi apresentado ao final da Conae. À vista disso, essas informações foram extraídas das atas das $1^{\mathrm{a}}, 2^{\mathrm{a}}, 3^{\mathrm{a}}, 4^{\mathrm{a}}$ e $5^{\mathrm{a}}$ reuniões da Conae realizadas em 2008 e 2009, da Portaria de Criação do Fórum Nacional de Educação, do Regimento Interno da Conae, das Normas Regulamentares da Comissão da Conae e das Portarias Normativas $n^{\circ}$ 828/2009, 13/2009, 17/2008, 10/2008 e da Portaria de Designação dos Membros da Conae. Além disso, os documentos referência, base e final foram utilizados para essa análise, bem como o conteúdo das entrevistas.

Destaca-se que a abordagem se restringiu às metas 12, 13 e 14 da Lei 13.005 de 2014, considerando o recorte feito pela Lei referida que se estrutura da seguinte forma: primeiro são definidas as diretrizes, depois as metas e dentro dessas há estratégias para alcançá-las. A partir daí são desenhadas as políticas que sustentarão o alcance dos objetivos principais dessas metas. Com isso, o ensino superior está inserido em três metas em que a de número 12 trata de educação superior, a 13 aborda a qualidade da educação superior e, por fim, a 14 considera a pós-graduação. Isso, portanto, delineia a visão do governo sobre as políticas que são definidas para cada área. 
Essa proposta apresentada pelo executivo e sociedade e posteriormente aprovada pelo congresso nacional culmina para a formulação de um Sistema Nacional de Educação baseado na colaboração e articulação entre os entes nacionais para atingirem as metas traçadas. Além disso, exige-se a formulação de planos estaduais e municipais de educação para melhor adequar as ações dos entes ao Plano Nacional de Educação. A seguir, serão apresentados os procedimentos metodológicos utilizados nesta pesquisa.

\subsection{Coleta de Dados}

Antes de explanar sobre os procedimentos de coletas de dados, é necessário esclarecer que a procedência deles tanto pode ser primária quanto secundária. No primeiro caso, a pesquisa tem como base os dados coletados em primeira mão pelo pesquisador. $\mathrm{O}$ segundo caso diz respeito aos dados já tratados, processados e analisados por outros (FARIAS FILHO, 2013). Nesse estudo, foram utilizados tanto dados primários quanto secundários. Um exemplo disso são as atas e os documentos originais da Conae.

A obtenção dos dados de pesquisa foi feita utilizando-se a técnica de coleta de dados. Em consonância com o que a literatura apresenta como técnicas de coleta, essa pesquisa adotou dois instrumentos: a pesquisa documental/ bibliográfica e a entrevista (FARIAS FILHO, 2013).

A pesquisa bibliográfica se refere ao levantamento de toda a bibliografia publicada sobre o assunto e tem por finalidade colocar o pesquisador em contato com o que já foi dito a respeito, permitindo reforço na análise das informações. Já a pesquisa documental consiste em analisar documentos que se constituem em fontes primárias de dados. São basicamente os materiais internos à organização (MARCONI; LAKATOS, 2010).

A coleta de dados do tipo documental permitiu obter a linguagem e as palavras dos participantes, o que nos levou a entender os confrontos e antagonismos presentes na Conae, e analisar as relações entre sociedade civil e representações governamentais no âmbito desse instituto. O principal objetivo dela foi trabalhar as fontes de evidência que o pesquisador precisa para responder aos questionamentos do estudo (FARIAS FILHO, 2013).

Baseado nisso, as fontes para a análise qualitativa acerca da participação social na formulação dos planos nacionais de educação são os seguintes documentos: Atas das $1^{\mathrm{a}}, 2^{\mathrm{a}}, 3^{\mathrm{a}}$, $4^{\mathrm{a}}$ e $5^{\mathrm{a}}$ reuniões da Conae realizadas em 2008 e 2009, Portaria de Criação do Fórum Nacional de Educação, Regimento Interno da Conae, Normas Regulamentares da Comissão da Conae e 
Portarias Normativas nº 828/2009, 13/2009, 17/2008, 10/2008 e Portaria de Designação dos Membros da Conae.

Posteriormente, foram realizadas entrevistas com a parcela da população estudada - atores da sociedade civil, atores que participaram da Conae, coordenadores e Secretários da SESU e do MEC. Pretendeu-se, com isso, construir informações pertinentes à participação social e sua influência na formulação dos PNES, tais como: a identificação das características da atuação do Conae; averiguação de existência de estratégias de fomento à participação da Conae; verificação da capacidade de influência da Conae; análise das relações entre sociedade civil e representações governamentais no âmbito da Conae e, por fim, averiguou a percepção do representante legal da SESU e do MEC sobre a importância da Conae na formulação de políticas de educação do nível superior.

O roteiro da entrevista foi elaborado de forma a atender aos objetivos específicos e a agregar as principais variáveis da pesquisa determinados anteriormente. As entrevistas são úteis quando os participantes não podem ser diretamente observados (CRESWELL, 2010). Ademais, justifica-se seu uso quando a pesquisa possui a necessidade de captar informações sobre opiniões, expectativa, motivação e informações passadas. A entrevista se subdivide em três tipos: estruturada, semiestruturada e livre. A estruturada é o conjunto de perguntas numa sequência com linguagem direta a fim de obter informação desejada pelo entrevistador além de usar um roteiro previamente definido. Na semiestruturada, as questões são mais abertas e exigem respostas mais profundas. Os questionamentos possuem um formato mais flexível e o entrevistado tem uma atuação mais dinâmica e livre. A última, entrevista livre, consiste numa abordagem mais geral do assunto e o entrevistado fica menos direcionado em sua resposta (FARIAS FILHO, 2013).

Assim, no caso dessa pesquisa, as entrevistas serviram para os participantes fornecerem informações relacionadas às características da Conae, a relação estabelecida entre o Estado e a sociedade por meio da Conae, a influência da Conae na elaboração de políticas referentes ao ensino superior e suas metas e as estratégias de fomento de participação social no Conae. Para tanto, foi realizada uma entrevista do tipo semiestruturada.

A seleção da amostra recrutou participantes com papeis diversos na Conae e que além de responder à questão central da pesquisa possuíssem envolvimento com o assunto e disponibilidade e disposição em tratar do tema proposto (DUARTE, 2005). Isto quer dizer que o procedimento de recrutamento empregou o princípio da heterogeneidade para maximizar o alcance da pesquisa. Dentro desse parâmetro adotam-se duas formas de aplicação desse princípio: variação máxima em que os participantes são propositalmente selecionados por 
apresentarem características diversas, e o outro é a bola de neve em que um participante indica o outro e assim por diante (SEINDMAN, 1998).

Inicialmente fez-se uma seleção baseada na variação máxima baseada no estudo das Portarias de Designação da comissão organizadora da Conae e de seus membros e das atas da conferência, contudo, em alguns casos, a informação obtida em entrevistas e quando do envio da carta convite era a de que determinados atores haviam participado mais ativamente que outros. A partir dessas informações a lista de entrevistados foi reestruturada. Utilizou-se, portanto, nesse último caso o procedimento de bola de neve.

As entrevistas duraram cerca de 1 hora. Aos entrevistados foram dirigidas perguntas baseadas num roteiro semiestruturado que contava com uma ordem preestabelecida para dar maior fluidez e que permitiu obter informações claras em relação ao objetivo da pesquisa. Ainda, segundo Duarte (2005), o roteiro foi focado no problema de pesquisa com perguntas abertas que permitiram a inclusão de novas questões a depender das respostas dos entrevistados. $\mathrm{O}$ objetivo principal dessa etapa foi o de complementar a análise documental. $\mathrm{O}$ roteiro completo encontra-se no Anexo 1 desse trabalho.

Em vista disso, dividiu-se em dois grupos de entrevistados, estando de um lado o roteiro de entrevistas para representantes da sociedade civil que participaram das discussões da Conae. Já no outro lado se encontrava o roteiro de entrevistas para representantes do governo que participaram da Conae.

Com o primeiro bloco de entrevistados objetivou-se averiguar a influência dos movimentos sociais em educação de nível superior na formulação das metas e estratégias do PNE II. A seleção dos entrevistados, em um primeiro momento, baseou-se na análise das portarias de designação dos membros da Conae - Portaria Normativa $n^{\circ} 17 / 2008$, Portaria Normativa $n^{\circ} 13 / 2009$ e Portaria Normativa $n^{\circ} 828 / 2009$. Contudo nos primeiros contatos com os entrevistados, observou-se que alguns membros designados nessas portarias não participaram efetivamente das reuniões da Conae. A partir daí, foram indicados entrevistados que participaram do processo de discussão e deliberação do documento referência, base e final. O primeiro bloco de entrevistados está indicado no quadro a seguir: 
Quadro 2: Entrevistados Bloco A - Representantes da sociedade civil

\begin{tabular}{|c|c|c|}
\hline Entrevistado(a) & Órgão/Entidade & Atribuições \\
\hline A & $\begin{array}{l}\text { Conselho Nacional de Educação } \\
\qquad(\mathrm{CNE})\end{array}$ & Conselheiro Titular do CNE \\
\hline B & Fórum Nacional de Educação & $\begin{array}{l}\text { Membro da Confederação } \\
\text { Nacional de Trabalhadores da } \\
\text { Educação (CNTE) }\end{array}$ \\
\hline C & $\begin{array}{c}\text { Associação Nacional de Pós } \\
\text { Graduação e Pesquisa em Educação } \\
\text { (ANPED) }\end{array}$ & Presidente da ANPED \\
\hline D & $\begin{array}{c}\text { Federação de Sindicatos de } \\
\text { Professores de Instituições Federais de } \\
\text { Ensino Superior (PROIFES) }\end{array}$ & $\begin{array}{l}\text { Membro do Sindicato } \\
\text { PROIFES }\end{array}$ \\
\hline
\end{tabular}

Fonte: Elaboração da autora

Já o segundo bloco foi composto por um perfil de representantes do governo que atuaram na comissão organizadora da Conae enquanto desempenhavam suas funções na SESU/MEC e SE/MEC. Com isso procurou-se compreender como o governo se articulou com os movimentos para a elaboração do documento contendo metas que influenciaram na formulação de políticas executadas pelo próprio governo. Dessa forma, buscou-se entender como esse grupo participou da elaboração do documento referência, base e final apresentado aos parlamentares e de que forma ele permitiu a participação dos movimentos na elaboração desse texto, tendo em vista o discurso de construção de políticas conjuntamente entre governo e sociedade previstas desde a concepção da Conae. 
Quadro 3: Entrevistados Bloco B - Representantes do governo

\begin{tabular}{|c|c|c|}
\hline \multicolumn{1}{|c|}{ Entrevistado(a) } & Órgão/Entidade & Atribuição \\
\hline \multirow{2}{*}{ E } & $\begin{array}{c}\text { Secretaria Executiva } \\
\text { F }\end{array}$ & $\begin{array}{c}\text { Secretário Executivo Adjunto } \\
\text { da Secretaria Executiva } \\
\text { (SE/MEC) }\end{array}$ \\
\hline & Secretaria de Educação & $\begin{array}{c}\text { Diretor de Políticas e } \\
\text { Programas de Graduação da } \\
\text { SESU/MEC }\end{array}$ \\
\hline G & Superior (SESU/MEC) & $\begin{array}{c}\text { Coordenador-Geral de } \\
\text { Expansão e Gestão das } \\
\text { Instituições Federais de } \\
\text { Ensino da SESU/MEC }\end{array}$ \\
\hline
\end{tabular}

Fonte: Elaboração da autora

Acerca das escolhas metodológicas do processo de seleção dos entrevistados, procurou-se buscar sujeitos com perspectivas plurais acerca do objeto de estudo. Essa abordagem permitiu formatar uma pesquisa que incluísse atores com diversos papeis em busca de um objetivo que era a elaboração do PNE II para mais tarde ter as suas ideias transformadas em políticas, programas e ações. Observou-se, contudo, que os entrevistados, apesar de estarem em grupos que representam interesses diversos uns dos outros e possuam opiniões e projetos divergentes; ainda assim eles concordam que deve haver espaços de discussão entre governo e sociedade civil para melhor entender as necessidades dos cidadãos.

Em vista disso, pode-se salientar que os grupos selecionados não se opuseram a ideia de participação social em si, entretanto existe a possibilidade de que em pesquisas do tipo survey se encontrem opositores dessa ideia. Dessa forma, pela maneira como esta pesquisa foi desenhada não há a possibilidade de se deparar com tais sujeitos que justamente por possuírem opinião tão diferente poderia contribuir com sua visão sobre o assunto.

A técnica que foi utilizada na seleção dos entrevistados possui limitações, pois se o objetivo era diversificar o rol de indivíduos, evitando que eles tivessem dentro de uma mesma perspectiva; a técnica bola de neve pode inibir esse resultado. Isso decorre do fato de que como o próprio entrevistado indica o outro, é possível que todos eles compartilhem de ideias e comportamentos semelhantes. Isso vai de encontro com o que se esperou da seleção, mas foi a técnica possível dentro das circunstâncias oferecidas.

Para traçar a lógica percorrida na elaboração do método da pesquisa serão apresentados no quadro a seguir os objetivos específicos, as ações e seus procedimentos metodológicos correspondentes. 
Objetivo específico 1: identificar e caracterizar os protagonistas que se envolveram no debate da política de educação de nível superior do PNE II no âmbito da Conae

\begin{tabular}{|c|c|}
\hline Ações & Procedimentos Metodológicos \\
\hline $\begin{array}{l}\text { Relacionar os protagonistas que } \\
\text { representaram governo e sociedade } \\
\text { civil na Conae para formulação do } \\
\text { PNE II }\end{array}$ & $\begin{array}{l}\text { Pesquisa bibliográfica e documental } \\
\text { (revisão de literatura e pesquisa } \\
\text { documental por meio dos } \\
\text { precedentes normativos: Portaria de } \\
\text { Criação do Fórum Nacional de } \\
\text { Educação, Regimento Interno da } \\
\text { Conae, Normas Regulamentares da } \\
\text { Comissão da Conae e Portarias } \\
\text { Normativas n } 828 / 2009,13 / 2009 \text {, } \\
\text { 17/2008, 10/2008 e Portaria de } \\
\text { Designação dos Membros da Conae } \\
\text { Entrevista semiestruturada: } \\
\text { perguntas } 1,2,3,4 \text { e } 5 \text { (roteiro A) e } 2 \\
\text { e3 (roteiro B) }\end{array}$ \\
\hline
\end{tabular}

Objetivo específico 2: identificar o papel dos protagonistas na Conae para formulação de políticas de educação de nível superior

\begin{tabular}{|l|l|}
\hline Ações & \multicolumn{2}{|c|}{ Procedimentos Metodológicos } \\
\hline $\begin{array}{l}\text { Relacionar as competências dos } \\
\text { representantes do governo e da } \\
\text { sociedade civil na formulação de } \\
\text { políticas de educação de nível } \\
\text { superior. }\end{array}$ & $\begin{array}{l}\text { Pesquisa bibliográfica e documental } \\
\text { (revisão de literatura e pesquisa } \\
\text { documental por meio dos } \\
\text { precedentes normativos: Portaria de } \\
\text { Criação do Fórum Nacional de } \\
\text { Educação, Regimento Interno da } \\
\text { Conae, Normas Regulamentares da } \\
\text { Comissão da Conae e Portarias } \\
\text { Normativas n 828/2009, 13/2009, } \\
17 / 2008,10 / 2008 \text { e Portaria de } \\
\text { Designação dos Membros da Conae } \\
\text { Entrevista semiestruturada: } \\
\text { perguntas 6, 7, 8, 9 e 11 (roteiro A) } \\
\text { e 1,4,6, 7, 8, 9, 10 e 11 (roteiro B) }\end{array}$ \\
\hline
\end{tabular}

Objetivo específico 3: Compreender como se deu a atuação da Conae na elaboração do PNE II no que se refere às políticas de educação de nível superior 


\begin{tabular}{|c|c|}
\hline Ações & Procedimentos Metodológicos \\
\hline $\begin{array}{l}\text { Relacionar os representantes da } \\
\text { sociedade que participaram das } \\
\text { discussões sobre as políticas de } \\
\text { educação de nível superior no âmbito } \\
\text { da Conae para construção do PNE II }\end{array}$ & $\begin{array}{l}\text { Pesquisa documental por meio dos } \\
\text { seguintes textos: Documento Base } \\
\text { do Conae e Documento Final, } \\
\text { Ementas dos Colóquios, Documento } \\
\text { Referência, Emendas da Câmara dos } \\
\text { Deputados e Senado Federal }\end{array}$ \\
\hline $\begin{array}{l}\text { Apresentar as janelas políticas de } \\
\text { oportunidade definidas pelo modelo de } \\
\text { John Kingdom - Multiple Streams que } \\
\text { foram abertas em relação às metas } \\
\text { referentes às políticas de educação de } \\
\text { nível superior }\end{array}$ & $\begin{array}{c}\text { Revisão de literatura e } \\
\text { semiestruturada: perguntas 1,2,3,4 e } \\
5 \text { (roteiro A) e } 2 \text { e } 3 \text { (roteiro B) }\end{array}$ \\
\hline $\begin{array}{l}\text { Discorrer sobre a institucionalização } \\
\text { da participação social no âmbito da } \\
\text { educação por meio das conferências - } \\
\text { Conae. }\end{array}$ & \begin{tabular}{|c} 
Revisão de literatura e pesquisa \\
documental a partir das experiências \\
nacionais de participação social por \\
meio dos seguintes precedentes \\
normativos: Portaria de Criação do \\
Fórum Nacional de Educação, \\
Regimento Interno da Conae, \\
Normas Regulamentares da \\
Comissão da Conae e Portarias \\
Normativas $\mathrm{n}^{\circ} 828 / 2009,13 / 2009$, \\
17/2008, 10/2008 e Portaria de \\
Designação dos Membros da Conae.
\end{tabular} \\
\hline $\begin{array}{c}\text { Entrevistar representantes da } \\
\text { sociedade civil que compuseram os } \\
\text { grupos de discussão sobre as políticas } \\
\text { de educação de nível superior no } \\
\text { âmbito da Conae para construção do } \\
\text { PNE II }\end{array}$ & $\begin{array}{l}\text { Entrevista } \\
\text { perguntas } 6,7,8,9 \text { e } 11 \text { (roteiro A) } \\
\text { e } 1,4,6,7,8,9,10 \text { e } 11 \text { (roteiro B) }\end{array}$ \\
\hline
\end{tabular}

Objetivo específico 4: Averiguar a percepção dos representantes governamentais e da sociedade civil sobre os objetivos, funcionamento e importância da Conae na formulação de políticas de educação relacionadas à educação de nível superior 


\begin{tabular}{|c|c|}
\hline Ações & Procedimentos Metodológicos \\
\hline $\begin{array}{c}\text { Identificar na deliberação final da } \\
\text { Conae a relação existente com as } \\
\text { metas e estratégias estabelecidas na } \\
\text { Lei 13.005/2014 (PNE II) }\end{array}$ & $\begin{array}{c}\text { Pesquisa documental (atas e } \\
\text { relatórios da Conae - 2010) }\end{array}$ \\
\hline $\begin{array}{c}\text { Entrevistar representantes do governo } \\
\text { que compuseram os grupos de } \\
\text { discussão sobre as políticas de } \\
\text { educação de nível superior no âmbito } \\
\text { da Conae para construção do PNE II }\end{array}$ & $\begin{array}{c}\text { Entrevista semiestruturada: } \\
\text { perguntas 10 (roteiro A) e 5 (roteiro }\end{array}$ \\
\hline
\end{tabular}

No próximo item serão apresentadas as categorias de análise e a análise de conteúdo a partir da definição dos objetivos específicos e do tratamento dos dados coletados nas entrevistas e nos documentos.

\subsection{Categorização e análise de conteúdo}

Para analisar os dados extraídos dos procedimentos relatados acima, foi utilizada a técnica da análise de conteúdo. Esta técnica possui as características de objetividade, sistematização e inferência com relação a conteúdos advindos de discursos diversos e possibilita a obtenção, por meio da descrição do conteúdo das mensagens, de indicadores que permitiram inferir conhecimentos relativos às condições de produção e recepção das mensagens (MARCONI E LAKATOS, 2013).

A análise de conteúdo demandou analisar as informações para depois desenvolver uma matriz de análise que permitiu comparar o conteúdo das informações com os objetivos da pesquisa e as questões da pesquisa e com os argumentos e conclusões dos principais autores da bibliografia usada. Somado a isso, foi necessário verificar se os conceitos, categorias e variáveis do referencial teórico se manifestaram no conteúdo dos documentos. E, finalmente, extrair as conclusões do confrontamento entre a teoria do referencial e a prática personalizada pelos documentos, relatórios e atas (FARIAS FILHO, 2013).

Foram definidas três categorias de análise e discussão dos dados dessa pesquisa com base nos objetivos específicos:

a) Mapeamento e caracterização dos atores que compõem a Conae: esta categoria analisou quem são os atores que participaram da Conae e quais os papeis exercidos por eles; 
b) Influência da Conae na elaboração de políticas referentes à educação de nível superior, bem como de suas metas: esta categoria discutiu a formulação de políticas a partir das definições das metas e do documento base enviado aos parlamentares e a influência da participação social a partir da atuação do Conae e dos movimentos na elaboração do PNE II;

c) Relação entre Estado e sociedade no âmbito da Conae: esta categoria objetivou entender de que forma os movimentos sociais e governos se relacionavam e qual foi o grau de abertura dada ao primeiro grupo permitindo sua efetiva participação na elaboração do PNE II;

No próximo capítulo serão apresentados o campo de estudo e os resultados da pesquisa de campo divididos de acordo com as categorias acima definidas a partir dos objetivos específicos. 


\section{RESULTADOS E DISCUSSÕES}

Este capítulo trata dos resultados e discussões acerca das categorias de análise explicitadas na metodologia dessa pesquisa. Na primeira subseção, será apresentado o campo de estudo dessa pesquisa que se caracteriza por ser a instância de participação social onde o PNE II foi construído: a Conae. Nas subseções seguintes, serão expostas as análises acerca da caracterização dos protagonistas que se envolveram no debate do PNE II sobre educação de nível superior, a partir do estudo da composição, competências, organização da Conae e da metodologia adotada por ela. Ademais, examinar-se-á o papel desempenhado pelos atores na formulação de políticas de educação de nível superior e a influência que exercem nela. Por fim, a pesquisa se debruçará sobre a relação entre o Estado e a sociedade no âmbito da Conae.

\subsection{A Conae e o PNE II}

A construção do PNE II se deu a partir das indicações de diretrizes apresentadas nas conferências de educação que ocorreram ao longo dos anos de 2008 a 2010. Essas conferências articularam órgãos educacionais, congresso nacional, sociedade civil e governo, constituindo-se como um ambiente onde se formula, planeja e implementa políticas públicas de educação.

A democratização das relações de poder não veio imediatamente com o processo de redemocratização do país. Adiciona-se a isso o fato de que a democracia brasileira coexiste com práticas autoritárias e clientelistas (TELLES, 1999). A prática de participação da sociedade civil na construção de políticas por meio de conferências tornou-se mais presente com o governo Lula (AVRITZER, 2012). E é por meio dela que a construção de políticas de educação se deu.

A exposição de motivos $n^{\circ} 33$ que trata da submissão ao Presidente da República o Projeto de Lei que aprova o Plano Nacional de Educação para o decênio 2011-2020 justifica o relevante papel daquele documento como o marco de tratar a política de educação como política de Estado. Isso quer dizer que não é apenas uma política construída apenas dentro do governo e, sim, construída pela sociedade e para a sociedade (CÂMARA DOS DEPUTADOS, 2011).

Nesse contexto, a Conae/2010 ocorrida em Brasília, sob o tema Construindo um Sistema Nacional Articulado de Educação: Plano Nacional de Educação, suas Diretrizes e Estratégias de Ação, foi antecedida por 27 conferências estaduais e 378 conferências 
municipais realizadas em 2009 (CONFERÊNCIA NACIONAL DE EDUCAÇÃO, 2010). A metodologia adotada nos encontros também contribuiu para o aprofundamento da discussão acerca de determinados temas. O documento referência que foi apresentado nessas etapas local e regional foi acrescido de 5.300 deliberações sobre questões relativas aos seus contextos (CONFERÊNCIA NACIONAL DE EDUCAÇÃO, 2010).

A partir do documento referência, foi elaborado o documento base da etapa nacional com 2057 emendas. Esse total foi dividido em dois blocos: aquelas que tiveram aprovação em cinco ou mais estados e aquelas que foram aprovadas em menos de cinco estados. Esse documento foi levado aos delegados e participantes credenciados, tendo sido discutido nas plenárias de eixo na plenária final. Eram basicamente seis eixos temáticos:

I. Papel do Estado na garantia do direito à educação de qualidade: organização e regulação da educação nacional;

II. Qualidade da educação, gestão democrática e avaliação;

III. Democratização do acesso, permanência e sucesso escolar;

IV. Formação e valorização dos/das profissionais da educação;

V. Financiamento da educação e controle social;

VI. Justiça social, educação e trabalho: inclusão, diversidade e igualdade.

Dessas plenárias, resultaram 694 emendas para a deliberação da plenária final. Nesta, foram aprovadas 677 emendas e o conteúdo resultante desse processo foi apresentado como documento final.

Com a experiência da Conae e para atender uma reivindicação histórica da sociedade brasileira, foi instituído pela Portaria n 1407/2010 do MEC o Fórum Nacional de Educação (FNE). Ele é, portanto, um órgão de Estado, pois vincula-se ao Ministério da Educação e é composto por 45 entidades nacionais entre representantes da sociedade civil e órgãos públicos. Cabe ao FNE coordenar as Conferências Nacionais de Educação e acompanhar as suas deliberações inclusive a tramitação do PNE no Congresso Nacional. Além dessas, as atribuições do FNE são as seguintes:

I. Participar do processo de concepção, implementação e avaliação da política nacional de educação;

II. Acompanhar, junto ao Congresso Nacional, a tramitação de projetos legislativos referentes à política nacional de educação, em especial a de projetos de leis dos planos decenais de educação definidos no Artigo 214 da Constituição Federal, com alterações da Emenda à Constituição 59/2009;

III. Acompanhar e avaliar os impactos da implementação do Plano Nacional de Educação; 
IV. Acompanhar e avaliar o processo de implementação das deliberações das conferências nacionais de educação;

V. Elaborar seu Regimento Interno e aprovar ad referendum o Regimento Interno das conferências nacionais de educação;

VI. Oferecer suporte técnico aos Estados, Municípios e Distrito Federal para a organização de seus fóruns e de suas conferências de educação;

VII. Zelar para que os fóruns e as conferências de educação dos Estados, do Distrito Federal e dos Municípios estejam articulados à Conferência Nacional de Educação;

VIII. Planejar e coordenar a realização de conferências nacionais de educação, bem como divulgar as suas deliberações.

Com o advento do FNE, sendo vinculado ao MEC, percebe-se que há um esforço do Estado para dialogar com protagonistas da área de educação a fim de construir práticas mais democráticas de políticas públicas. Considerando que diferentes entidades estão ali representadas oportunizando diálogos entre grupos diversos e que apresentam divergências entre si, o amadurecimento dos debates sobre a responsabilidade do Estado no que se refere ao acesso à educação de nível superior como um direito social na Conae é de suma relevância para elevar a educação ao status de política de Estado.

Em se tratando especificamente do PNE e da política de educação de nível superior - metas 12, 13 e 14 diretamente e indiretamente as metas 15 e 16 -, observou-se que as estratégias definidas no documento final foram substancialmente ampliadas na fase de tramitação do projeto na câmara dos deputados. Num primeiro momento, o texto enviado à Câmara, e que posteriormente foi enviado ao Senado Federal e retornou à Câmara novamente, resultou em duas propostas. Essa última fase foi marcada por intensas disputas.

As duas mudanças cruciais nos textos que tramitaram na casa legislativa giraram em torno da supressão da meta 12 que se referia à expansão do ensino superior público em $40 \%$ e a supressão da estratégia 12.20 cujo conteúdo tratava da ampliação dos recursos do FIES e PROUNI. Além dessa, houve mais 16 mudanças de estratégias, mas que mantiveram o mesmo conteúdo não contribuindo para mudanças significativas do que havia sido decidido pela sociedade civil. Nesse momento específico, a sociedade civil, alguns parlamentares e o governo federal defenderam a aprovação integral do PNE tal como fora entregue ao parlamento e consideraram o substitutivo do Senado um retrocesso às conquistas conseguidas pela educação (COSTA, 2014).

Após esse processo de mobilização das entidades na arena parlamentar, o texto do PNE foi aprovado com o texto base do Deputado Ângelo Vanhoni (PT-PR, tendo sido 
rejeitado dois destaques advindos do Senado que se referiam à aplicação dos $10 \%$ do PIB na educação do setor público (suprimiram a palavra público) e, além disso, retiraram o texto que obrigava a União a complementar recursos dos estados e municípios para cumprir o CAQ.

Das metas de educação superior, a meta 12 (elevar a taxa bruta de matrícula da educação de nível superior para $50 \%$ e a taxa líquida para $33 \%$ da população entre 18 e 24 anos assegurada a qualidade de oferta e expansão de, pelo menos, $40 \%$ das matrículas nas instituições públicas) apresenta o maior desafio, pois necessita ampliar a taxa bruta de matrículas para $50 \%$ e taxa líquida para 33\%. O principal ponto que provoca discussão era garantir que $40 \%$ dessas matrículas fossem no setor público de ensino. Isso implica ampliar vagas das universidades públicas e criar novos institutos de ensino profissionalizante. Apesar de aprovada no parlamento, o cenário de expansão das universidades privadas se mantém (COSTA, 2014).

Após a apresentação do campo de estudo Conae, FNE e PNE, serão apresentados e analisados os resultados da pesquisa de campo, subdividindo-se nas categorias definidas a partir dos objetivos específicos. Dessa forma, a próxima seção vai se dedicar a analisar o papel dos protagonistas da Conae e a caracterizá-los. Em seguida, será feito um estudo sobre a influência da participação social por meio da conferência na formulação de políticas de educação de nível superior e, finalmente, será averiguada a relação estabelecida entre os atores do governo e da sociedade civil para compreender a dinâmica estabelecida nessa relação.

\subsubsection{Mapeamento e caracterização dos protagonistas}

A partir das informações contidas no Regimento Interno e nas portarias normativas do MEC, foram definidas as características da Conae com os seguintes aspectos: composição, competência, organização e funcionamento das reuniões segundo a metodologia utilizada. Também foram considerados nesta análise os relatos dos entrevistados.

\subsubsection{Composição da Conae e competências de seus membros}

A primeira categoria de análise se preocupa em examinar a escolha da comissão organizadora. Em seguida, investiga quais papéis ela ocupa, a partir do que está definido como sendo suas competências e finalidade. Para corroborar com este estudo, essa pesquisa se 
ocupará da análise de conteúdo dos depoimentos dos entrevistados acerca do que vivenciaram na prática das reuniões, bem como da análise documental da Conae.

Com relação ao processo de escolha, deve-se considerar que a Conferência Nacional de Educação, de caráter deliberativo, caracteriza-se por ser um espaço democrático aberto pelo Poder Público, cujo objetivo é apresentar, a partir de um diagnóstico da realidade da educação no Brasil, propostas para elaboração do II Plano Nacional de Educação, servindo com um ambiente onde todos possam participar do desenvolvimento da educação nacional (CONFERÊNCIA NACIONAL DE EDUCAÇÃO, 2010).

Haja vista essa definição, a comissão organizadora da Conae, designada pelo Ministro da Educação, foi composta pelas seguintes entidades: Secretaria Executiva Adjunta do Ministério da Educação do MEC, Secretaria de Educação Básica do MEC, Secretaria de Educação Superior do MEC, Secretaria de Educação Especial do MEC, Secretaria de Educação a Distância do MEC, Secretaria de Educação Profissional e Tecnológica do Ministério da Educação, Secretaria de Educação Continuada, Alfabetização e Diversidade do MEC, Comissão de Educação, Cultura e Esporte do Senado; Comissão de Educação e Cultura da Câmara dos Deputados, Conselho Nacional de Educação, Associação Nacional dos Dirigentes das Instituições Federais de Ensino Superior, Associação Brasileira dos Reitores das Universidades Estaduais e Municipais, Confederação Nacional de Estabelecimentos de Ensino, Associação Brasileira das Universidades Comunitárias, Conselho de Dirigentes dos Centros Federais de Educação Tecnológica, Conselho Nacional dos Secretários de Educação, União Nacional dos Dirigentes Municipais de Educação, Confederação Nacional dos trabalhadores em Estabelecimentos, Federação de Sindicatos de Trabalhadores de Universidades Brasileiras, Fórum de Professores das Instituições Federais de Ensino, Sindicato Nacional dos Servidores Federais da Educação Básica e Profissional, Fórum Nacional dos Conselhos Estaduais de Educação, União Nacional dos Conselhos Municipais de Educação, União Brasileira dos Estudantes Secundaristas, União Nacional dos Estudantes, Confederação Nacional das Associações de Pais e Alunos, Representação da Comunidade Científica, Representação Social do Campo, Representação dos Movimentos de Afirmação da Diversidade, Representação das Articulações Sociais em Defesa da Educação, Representação das Entidades de Estudos e Pesquisa em Educação, representação das Centrais Sindicais dos Trabalhadores e Representação das Confederações dos Empresários do "Sistema S" (CONFERÊNCIA NACIONAL DE EDUCAÇÃO, 2010).

Sobre a escolha da comissão organizadora, houve uma mudança em sua composição no ano de 2009. Nesse ano foi publicada a Portaria Normativa $n^{\circ} 13$ de 2009 que 
alterava a Portaria Normativa $n^{\circ} 10$ de 2008 acerca da designação dos representantes das entidades que fizeram parte da comissão organizadora. Antes havia 35 entidades e no ano seguinte diminuiu para 34 entidades. A entidade que deixa de fazer parte dessa comissão é o Sindicato Nacional de Docentes do Ensino Superior - ANDES/SN. Nas entrevistas realizadas não houve menção a essa saída.

A comissão organizadora possuía como competência a elaboração do documento referência que serviu de base para as discussões das etapas regionais e municipais. Nessas etapas, esse documento apresentaria emendas e dali sairia um documento base que mais tarde, na etapa nacional, se transformaria no documento final. Adicionalmente, segundo o regimento interno da Conae, essa comissão desenvolverá suas atividades observando-se atender aos aspectos políticos, administrativos e financeiros que sejam relevantes para a realização da Conae; acompanhar a preparação e o desenvolvimento das Conferências Municipais ou Intermunicipais, do Distrito Federal e Estaduais de Educação e realizar a etapa nacional da Conae (CONFERÊNCIA NACIONAL DE EDUCAÇÃO, 2010). Essas diretrizes se baseiam na portaria de normatização das atribuições da comissão, cujo documento é intitulado de: Normas Regulamentares da Comissão Organizadora da Conferência Nacional de Educação CONAE. Nele estão elencadas as competências da comissão, conforme quadro a seguir:

Quadro 4: Competência da comissão organizadora do Conae

a) Constituir Comissões Técnicas ou Especiais para a execução de ações que contribuam para o efetivo desenvolvimento da Conferência Nacional, em todas as etapas; (Dinâmica e Sistematização Mobilização e Divulgação - Infra-estrutura e Logística)

b) Deliberar sobre o Tema Central e os Eixos Temáticos da Conae 
c) Deliberar sobre a elaboração e reprodução do Documento-Referência sobre os eixos temáticos da Conae, a serem debatidos nas Conferências Municipais e Estaduais da Educação

d) Deliberar sobre definição dos critérios para o quantitativo de delegados e sua distribuição por Unidade Federativa

e) Deliberar sobre os critérios de participação nas etapas da Conferência e a definição de observadores para a Conae

f) Deliberar sobre a publicidade das informações e orientações para o desenvolvimento das Conferências Municipais, Estaduais, do Distrito Federal e Nacional

g) Deliberar sobre a elaboração e reprodução do Documento-Base sobre os eixos temáticos da Conae, resultado das propostas aprovadas nas Conferências Estaduais

h) Deliberar sobre a metodologia e a coordenação das atividades a serem desenvolvidas na Conae

i) Deliberar sobre a elaboração e reprodução do documento final da Conae, com o resultado das deliberações dos delegados, bem como da elaboração do Relatório Final

Fonte: Elaborado pela autora a partir do artigo $3^{\circ}$ da Portaria Normativa $n^{\circ} 10 / 2008$ que regulamenta a Comissão Organizadora da Conae.

Em relação à primeira competência, esta se divide em três comissões especiais, cada qual com uma competência específica. A primeira delas é a Comissão de Divulgação e Mobilização cuja responsabilidade é elaborar e implementar proposta de mobilização social e de apoio à organização das Comissões e Conferências Municipais ou Intermunicipais, Estaduais e do Distrito Federal de Educação. A segunda é a Comissão de Dinâmica e Sistematização que é responsável por colaborar na construção metodológica e temática da Conae, produzindo documentos (Documento Referência, Documento Base e Documento Final) e registros. A última comissão é a de Infraestrutura e Logística, que visa programar e acompanhar ações que garantam as condições necessárias para a realização da Conae (materiais, equipamentos, espaços e atividades culturais). Tanto no regimento quanto na portaria referida, as competências estão em consonância com o relato dos entrevistados que ratificaram essa informação quando demandados sobre a participação do MEC/Entidade na comissão organizadora da Conae. Consoante os entrevistados, E - representante da Secretaria Executiva do MEC -, D - representante da PROIFES, e A - representante do Conselho Nacional de Educação:

O Ministério da Educação, por meio da Secretaria Executiva Adjunta, funcionou como a Secretaria Executiva da Conferência Nacional da Educação. Inicialmente a Conferência Nacional da Educação de 2010 foi organizada por uma comissão nacional composta de entidades que representavam os segmentos dos setores da educação brasileira. Essa comissão organizadora nacional foi articulada por meio dessa secretaria executiva adjunta do MEC e todo o planejamento da conferência e toda a realização da conferência, a secretaria executiva adjunta garantiu. Do suporte administrativo e financeiro para que a conferência acontecesse (ENTREVISTADO E, 2015). 
Bom como a representação no fórum nacional e também ele se reproduz nos fóruns estaduais, quase as mesmas representações, evidente que aqui no fórum nacional temos as grandes entidades e nos fóruns estaduais nós temos entidades filiadas a essas outras entidades, não é? (ENTREVISTADO D, 2015).

Então inicialmente dizer que participei das conferências, venho participando desde 2008 da Conferência Nacional de Educação Básica, as Conferências Nacionais de Educação de 2010 e a de 2014, e fui responsável pela coordenação da elaboração do documento dessas conferências, ou seja, o documento básico foi discutido nos diferentes, nas conferências municipais, regionais, estaduais, quer dizer, eu fiz parte, fiz parte da consolidação do documento final da CONEBE 2008 e da Conae 2010, 2014 (ENTREVISTADO A, 2015).

Um aspecto a ser acrescentado é que o desenho da Conae se baseou na experiência de duas conferências na área da educação: I Conferência Nacional de Educação Profissional e Tecnológica e a Conferência Nacional da Educação Básica - CONEB. Isso inclui a indicação de alguns representantes que já faziam parte da CONEB e da Conferência Nacional de Educação Profissional e Tecnológica para constituírem a comissão da Conae, conforme excerto da ata da Reunião Ordinária realizada em 21 de outubro de 2008:

Informou que essa primeira reunião da Conae estava sendo uma continuidade das conferências já ocorridas no âmbito do Ministério da Educação, e citou como exemplo, a realização da I Conferência Nacional de Educação Profissional e Tecnológica e a Conferência Nacional da Educação Básica CONEB, que trouxeram como resultado um acúmulo de conhecimento e de acervo de documentos, os quais estavam sendo repassados a todos da reunião. [...]. Agradeceu a todas as entidades que mantiveram as indicações dos mesmos representantes que participaram da CONEB, para constituírem a comissão da Conae, visto que a experiência desses, contaria muito (ATA, 2015).

Como se pode observar, além de outras conferências servirem, metodologicamente, de fundamento para a Conae, atores que compuseram a comissão organizadora desses institutos participativos na área de educação, como a CONEB, foram designados a participar da comissão da Conae por causa das suas experiências na gestão de políticas participativas. No âmbito de entidades que representam a educação de nível superior isso se aplica de maneira indireta. Isso porque entidades que cuidaram de assuntos relacionados ao ensino superior no PNE II também participaram da conferência relativa ao ensino de educação básica. Segundo o entrevistado A - representante do Conselho Nacional de Educação (CNE):

fiz parte da consolidação do documento final da CONEBE 2008 e da Conae 2010, 2014 então a gente já vinha fazendo trabalho de avaliação e nas discussões no âmbito do próprio Ministério da Educação, quer dizer, então esse trabalho de avaliação ele serviu como elemento, assim como os 
documentos da Conae que estava diretamente vinculados à temática do PNE, interferiram na construção do PNE

Essa comissão organizadora da Conae, em certa medida, conta com representantes que possuem conhecimento de como funciona o processo de participação democrática. Isso se deve ao fato de que a promoção de espaços de discussão para tratar de políticas de educação que circunscrevesse diferentes entes da sociedade civil, segundo os entrevistados $\mathrm{E}$, da Secretaria Executiva do MEC e B, da Confederação Nacional dos Trabalhadores da Educação (CNTE), vem sendo tentada desde 1996 com a criação da Lei de Diretrizes e Bases (LDB) que exigiu a criação de um Plano Nacional de Educação. Diante desse fato, entes da sociedade civil reuniram-se para enviar ao Congresso Nacional um documento que representasse seus anseios de políticas no âmbito da educação. Contudo, o governo apresentou seu próprio Plano e que teve prioridade no processo de tramitação, gerando uma disputa de Planos. Segundo os discursos dos entrevistados,

O primeiro Plano Nacional a Educação, ele foi circunstancial. Enquanto o segundo Plano Nacional da Educação, ele foi definido nas disposições transitórias da LDB de 96 pare atender à década da educação. A $1^{\circ}$ Conae pautou o PNE como decenal com uma política permanente, uma política de estado, e propôs que a legislação fosse alterada para que nós não tivéssemos só um Plano Nacional da Educação decenal, mas tivéssemos planos decenais permanentes (ENTREVISTADO E, 2015).

Então como o governo não enviou o plano como deveria, como a lei determinava ao realizar esse encontramos, nos produzimos um plano e protocolamos no congresso nacional através de parlamentares na área da educação. Depois que protocolamos o nosso lado, foi que o governo correu atrás de fazer o dele de gabinete, e depois protocolou depois o dele que terminou tendo prioridade no processo de tramitação, mas mesmo assim nós conseguimos avançar na parte de financiamento (ENTREVISTADO B, 2015).

Percebe-se com isso que os atores participantes da elaboração do PNE II já haviam composto, mesmo que em circunstâncias distintas, comissões de entidades de representantes da sociedade civil. Essa experiência influenciou diretamente na maneira como as reuniões foram conduzidas e na definição da melhor forma de trabalho a ser executada e que produziria melhores resultados.

A comissão organizadora, composta por representantes da sociedade civil e do governo, se manteve do início ao fim, segundo documentos publicados no Diário Oficial da União - Portarias $n^{\circ} 17 / 2008$ e 828/2009 -, contudo nas atas de reuniões percebe-se, sobretudo no âmbito do governo, mudança nos nomes que compõem a comissão organizadora. Há casos também em que mudanças no quadro de pessoal dos órgãos do Executivo proporcionaram essas diferenças na composição da comissão. Durante as entrevistas, essas alterações foram ressaltadas. Isso pode ser constatado a partir do discurso do 
entrevistado F - representante da SESU/MEC - a seguir: "eu acompanhei grande parte do processo de fora, não daqui, depois... depois sim, no final eu estive aqui, mas a parte inicial eu acompanhei de fora".

Em relação ao ensino de nível superior, o entrevistado E - representante do governo - afirmou que para a elaboração do documento base a participação do conselheiro do CNE foi fundamental. Esse nome foi mencionado em entrevista, contudo não estava presente na lista de portaria a designação dos representantes dessa instituição. Isto é, na lista dos representantes designados oficialmente pelo CNE e que participaram das reuniões, conforme apresentam as atas, não continha o membro do CNE que teve relevante participação na elaboração do texto base e que mais tarde foi levado ao Congresso Nacional.

Acrescenta-se a isso o fato de que a participação da SESU/MEC enquanto comissão organizadora foi requerida, pois a mobilização de seus representantes nas reuniões era baixa, conforme consta na ata da $4^{\text {a }}$ reunião ordinária realizada em 24 de abril de 2009: "Em seguida, foram tirados os seguintes encaminhamentos: [...] fazer uma Reunião com a SESU e a SETEC, para solicitar uma maior mobilização nessas duas áreas”.

\subsubsection{Organização e metodologia da Conae}

Um dos principais objetivos da Conae foi a definição das bases para a elaboração do texto do II Plano Nacional de Educação. Para alcançá-lo, reuniram-se os governos dos estados e municípios com a sociedade civil a fim de discutir sobre a educação, buscando a construção de um sistema nacional articulado. Para tanto, o tema central foi "Construindo um Sistema Nacional Articulado de Educação: Plano Nacional de Educação, suas Diretrizes e Estratégias de Ação" (BRASIL. Conae, 2010). A discussão em torno do texto-referência poderia receber emendas apresentadas por grupos de pessoas, entidades ou pessoalmente. Somente nessa etapa e na estadual isso aconteceu. $\mathrm{O}$ documento advindo dessas etapas seria $\mathrm{o}$ documento-base que, na etapa nacional, não pôde apresentar emendas. Nesse momento a discussão se envolve em torno daquilo que ficaria ou que seria retirado do texto.

As etapas municipais abrangeram 17 estados. São eles: Tocantins, Sergipe, São Paulo, Santa Catarina, Rondônia, Rio Grande do Sul e Rio Grande do Norte, Rio de Janeiro, Piauí, Pernambuco, Paraná, Paraíba, Minas Gerais, Distrito Federal, Ceará, Bahia e Alagoas. Cada conferência municipal era composta por sete eixos temáticos: O Plano Nacional de Educação e o Sistema Nacional de Educação: Organização e Regulação, Educação e 
diversidade: justiça social, inclusão e direitos humanos, Educação, trabalho e desenvolvimento sustentável: cultura, ciência, tecnologia, saúde e meio ambiente, Qualidade da Educação: democratização do acesso, permanência, avaliação, condições de participação e aprendizagem, Gestão Democrática, Participação Popular e Controle Social e Valorização dos Profissionais da Educação: formação, remuneração, carreira e condições de trabalho, Financiamento da Educação: gestão, transparência e controle social dos recursos. A ideia era que os debates nas Conferências Municipais de Educação deveriam se orientar por uma visão ampla, abrangente, inclusiva e sistêmica da educação, primando pela garantia do processo democrático, pela promoção da pluralidade de ideias, identidades e expressões e pela consideração à representatividade dos segmentos e setores sociais (CONFERÊNCIA NACIONAL DE EDUCAÇÃO, 2010).

Acerca das discussões que envolveram as etapas municipais, em relação ao ensino de nível superior, foi baixa ou inexistente em alguns municípios ou, ainda, se caracterizava mais pela busca de informação. Os grupos não possuíam propostas bem definidas e elaboradas, segundo os entrevistados B e F, representantes da sociedade civil e governo, respectivamente:

e nós temos na regra da Conae, que para você participar da etapa estadual, é obrigado a participar da etapa municipal. Então para participar da etapa nacional, é obrigado a entrar na etapa estadual, então você tem que estar participando das três etapas para se tornar um delegado dentro da Conae. E isso exige um processo de participação desse município, que o primeiro momento o envolvimento da educação profissional, e superior foi baixo, mas na Conae de 2014, já melhorou (ENTREVISTADO B, 2015).

Então, olha todos os eventos em que eu participei, eu diria que a participação foi muito em termos de busca de informações sobre Educação Superior, a Educação Superior está longe de ser um tema popularizado. As pessoas frequentemente não têm a noção exata do quê que exatamente, então eu sempre fiz muita questão de ir para esses encontros com muita informação para dar, organizando informação, porque era o que eu sentia que as pessoas mais queriam, elas querem saber como funciona o sistema, como é que a gente está organizado nacionalmente, dificilmente eles têm ideia, por exemplo, de que existe uma coisa chamada Conselho Nacional. Falando, sabe que estabelece diretrizes que devem inspirar os projetos pedagógicos, que inspira um exame nacional com o ENADE, são esses triângulos aí, mas frequentemente não são percebidos. Agora eles sabem o que eles querem, em geral, por exemplo, o quê que eles querem? Eles querem ter acesso ao Ensino Superior, querem facilitar o acesso e aí essas questões são sempre trazidas, como é que é possível ofertar isso para mais gente. Então eu diria que a tônica, as duas seriam essas, primeiro tentar saber o que quê, como é que funciona em dois, tentar garantir que mais pessoas tenham acesso à Educação Superior, especialmente no interior (ENTREVISTADO F, 2015).

A partir das definições das plenárias municipais, era formada a base para discussão das etapas estaduais. Nesse momento participaram os 27 estados. Para dar andamento ao processo de debate, formaram-se três comissões, cada qual com uma 
competência específica. A primeira delas é a Comissão de Divulgação e Mobilização cuja responsabilidade é acompanhar o desenvolvimento das responsabilidades municipais. Ressalta-se que para ter acesso à etapa nacional, os delegados deverão participar das etapas anteriores da Conae. A segunda é a Comissão de Dinâmica e Sistematização que é responsável por adequar à proposta metodológica da conferência à realidade estadual, sistematizando as propostas advindas das etapas municipais, bem como elabora o processo de inclusão das emendas vindas dos municípios e, por fim, elabora o documento final da etapa estadual a partir das deliberações da plenária final. A última comissão é a de Infraestrutura e Logística que visa garantir os insumos necessários para a presença dos participantes de forma segura e adequada.

A composição de participantes na etapa estadual e municipal é de $2 / 3$ de representantes dos segmentos (gestores federais, municipais, privados e trabalhadores em educação do setor público e privado) e 1/3 de representantes dos setores (representação dos Movimentos de Afirmação da Diversidade e das Articulações sociais em Defesa da educação; representação da comunidade Científica; Representação Social do Campo; Movimento Sindical, instituições religiosas; empresários e confederações patronais etc) e daqueles que serão delegados de indicação nacional e delegados natos. A proporcionalidade dos segmentos obedece ao previsto pela etapa nacional, conforme quadro a seguir com relação ao ensino superior:

Quadro 5: Composição dos atores das etapas das Conferências Estaduais de Educação

\begin{tabular}{|l|c|}
\hline Gestores de Instituições Federais de Educação Superior & $5 \%$ \\
\hline Gestores Estaduais e Municipais de Estabelecimentos de Educação Superiror & $5 \%$ \\
\hline Gestores da Educação Superior Privada & $10 \%$ \\
\hline Trabalhadores da educação superior privada & $25 \%$ \\
\hline Funcionários técnicos administrativo da educação superior pública & $10 \%$ \\
\hline Docentes da Educação Superior Pública & $10 \%$ \\
\hline Estudantes & $35 \%$ \\
\hline
\end{tabular}

Fonte: Elaborado a partir do documento de orientação para a realização das etapas estaduais (CONFERÊNCIA NACIONAL DE EDUCAÇÃO, 2010).

Nas etapas estaduais, observa-se o mesmo esvaziamento de discussão que aconteceu nas etapas municipais. Essas informações foram extraídas das entrevistas, conforme respostas acima apresentadas, pois as atas e documentos não apresentam um resumo 
das discussões ocorridas no âmbito desses espaços. É válido lembrar que o mesmo procedimento de deliberação adotado na etapa municipal vale para a estadual. Isso quer dizer que o documento referência deveria receber propostas que foram submetidas e apreciadas pelas mesas dos eixos temáticos e posteriormente pelos delegados.

Após essas reuniões, o documento referência foi apresentado na Conae, e nele decidiu-se o que permanecia ou seria retirado. Não houve emendas nesse momento. Conforme relato do entrevistado $\mathrm{B}$, representante da sociedade civil - CNTE,

\begin{abstract}
A conferência nacional partiu de um documento referência construído pela comissão organizadora, formado por diversas entidades nacionais. Entidades da educação básica, profissional, superior, público e privado, considerando todos os seguimentos da educação, que são os trabalhadores, gestores, estudantes, pais e mães e os setores envolvidos pelo processo educacional, um movimento que defende a educação, centrais sindicais, confederações e patrões, diversas entidades e movimentos sociais que tem envolvimento com educação que compõe a comissão organizadora. E essa comissão produziu um documento referência, consensuado aquilo que não fosse divergente entre as forças, e das comissões, as entidades das comissões organizadoras, e esse documento referência foi para o debate nas etapas municipais e estaduais da conferencia de educação, e lá recebeu as emendas que foram apresentadas pessoalmente ou por grupo de pessoas ou por entidades nesse conjunto. Com essas emendas incorporadas ao documento referência, ele se transformou em um documento base. Esse documento base foi discutido na etapa nacional, na etapa nacional pela regra estabelecida não poderia ser apresentada novas emendas, as emendas deveriam ser consideradas nas etapas municipais e estaduais. Esse documento base, na etapa nacional, ele foi discutido nas emendas dos municípios do estado o que fica e o que não fica. E esse debate aconteceu na etapa nacional, produzindo documento final da conferência. Esse documento final da conferência de 2010, ele foi a base de todo um processo de discussão que nós utilizamos na tramitação do plano nacional da educação, que ele teve o projeto de lei, colocado no congresso nacional pelo poder executivo no final do ano de 2010 (ENTREVISTADO B, 2015).
\end{abstract}

Isto permite dizer que para a elaboração do documento base foram consideradas apenas as emendas que foram votadas e aprovadas nas conferências estaduais e que por consequência tiveram a sua apreciação na etapa municipal. Para compor o documento base, as emendas obtiveram aprovação da maioria simples nas conferências estaduais em no mínimo cinco estados da federação. A condução das conferências com apreciação de textos que vinham desde a etapa municipal e as deliberações que operaram em diferentes espaços, envolvendo a participação de diferentes atores, constitui o que Faria, Silva e Lins (2012) denominaram de sistema integrado de deliberação.

A partir das deliberações da Conae sobre o documento base produziu-se o documento final. Esse documento foi entregue ao Poder Executivo, entretanto ele não compôs o documento entregue ao Congresso Nacional. O texto que se tornou o Projeto de Lei 8.035/2010 foi elaborado pelo Poder executivo e divergia do documento final da Conae. A 
Conae 2010 também discutiu sobre a criação do Fòrum Nacional de Educação (FNE), uma reivindicação histórica da comunidade de educação. Ele possui caráter permanente e foi criado por Portaria do Ministério da Educação $n^{\circ} 1.407 / 2010$ e instituído por lei com a aprovação do PNE. Observa-se que a comissão organizadora da Conae foi a principal incentivadora da criação do Fórum, segundo relato do entrevistado B - representante do CNTE. Com isso, a composição do FNE é próxima ao que se tinha configurado na Conae. Essa forma de agir da sociedade e do governo, participando do processo de concepção, implementação e avaliação da política nacional de educação converge com a ideia de democracia deliberativa de Habermas (2003), que afirma que a democracia se legitima com discussões e decisões políticas dos cidadãos, corroborada também por Gohn (2014).

\subsubsection{Influência da participação social na elaboração do PNE II}

Com base nas entrevistas realizadas foram estabelecidos dois aspectos para análise da influência: contribuição das conferências nas formulações de políticas junto aos gestores e sociedade civil e sugestões para aperfeiçoar a influência da Conae na elaboração de políticas de ensino de nível superior.

4.1.2.1 Contribuições das conferências na formulação de políticas de educação de nível superior

Os entrevistados salientam que a forma como as conferências são realizadas, e, sobretudo, a metodologia adotada por elas, acabam por promover nos sujeitos que ali estão participando a formação política que contribuirá na construção de políticas públicas. Segundo o entrevistado A - representante do CNE:

\footnotetext{
De fato, quer dizer, é importante dizer que uma vez a Conae é um processo, inclusive o Plano Nacional de Educação reconhece a Conae, e chama atenção para a sua importância na dinâmica política. Então a Conae; de um lado ela interfere na medida em que é feito todo um processo de formação política nessas conferências, quer dizer, a própria discussão da temática nacional, e com seus desdobramentos na realidade estadual e municipal, quer dizer, todo esse processo, ele é formativo, então ele está levando a sociedade como um todo a participar do processo de discussão. Então aí qualifica profissionais da educação, pais, estudantes, gestores educacionais e, eles intervêm no movimento social, então quer dizer, tem uma ampla participação, quer dizer, uma ampla capilaridade (ENTREVISTADO A, 2015).
}

Além da capilaridade mencionada pelo entrevistado e da ampla participação que as conferências proporcionam à sociedade civil, há, sobretudo, a possibilidade de diálogo 
entre os diferentes setores com os órgãos gestores. Isso representa a ressignificação social acerca dos problemas que lhes afetam, levando a novas formas de ação social (HABERMAS, 2003). Em convergência com essa ideia, o entrevistado A, representante do CNE, afirmou que:

além disso, o documento da Conae, as deliberações que estão no seu documento final, elas resultam sempre em uma possibilidade dialógica, quer dizer, para esses diferentes setores. Quer dizer, quando vão discutir, seja no município, no estado ou mesmo na União com o Ministério da Educação, a referência é o documento da Conae, por que é uma referência de concepções, de indicações, de definição de política. Então há sim uma interface propositiva no campo da política, obviamente que nós vamos ter outros atores interferindo nesse campo, até porque a educação se constituiu no campo de disputa, disputa de concepções de projetos, de visão de mundo, de homem, de sociedade (ENTREVISTADO A, 2015).

Percebeu-se em relação à Conae que houve o fortalecimento do diálogo entre sociedade civil e Estado, a caracterizando, conforme preleciona Souza (2012), como canal democrático de participação no ciclo de políticas públicas. No grupo de entrevistados de representantes do governo também há um consenso de que as discussões que aconteceram na Conae foram importantes na elaboração das políticas. No discurso do entrevistado $G$ representante da SESU/MEC -, "hoje educação tem o mesmo movimento para a saúde e para outros sistemas; todos eles são baseados nessas conferências. E com a velocidade maior ou menor todas elas tendem a ser implementadas".

Além do que foi debatido nas conferências, a participação dos movimentos sociais ligados ao ensino de nível superior se deu em momento anterior ao da elaboração do documento referência que foi levado às conferências municipais e regionais para debate. Isso se deve ao fato de que há uma estreita ligação da comissão organizadora com os movimentos sociais. Dessa forma, o documento que foi levado a debate em certa medida já trazia reivindicações dos movimentos ligados à educação de nível superior. Conforme discurso do entrevistado F, representante da SESU/MEC:

Nas deliberações finais, porque nas deliberações finais o desenho já estava praticamente construído, porque também as pessoas que elaboraram o texto básico do PNE, eram pessoas ligadas aos movimentos sociais, quando pega um Luiz Dourado, ou um Chagas, que eram pessoas militantes, eram pessoas diretamente articuladas com os movimentos sociais. Então todas as associações que discutem essa, e esse pessoal ouvem os movimentos, não são surdos. Então o que estava no texto final é trazido por essas pessoas para dentro do governo, o projeto sai, ele já sai basicamente definido. Mas isso não quer dizer que ele saia fechado, mas ele sai com um esqueleto na estrutura básica de quem já ouviu movimentos sociais antes, então não é totalmente novo (ENTREVISTADO F, 2015). 
Nesse relato percebeu-se que pelo menos um integrante da comissão organizadora já possuía contato com os movimentos sociais e que de alguma forma eles estariam sendo escutados em um processo anterior aos das discussões previstas legalmente nas normas. Com essa observação deve-se ter cautela, pois apesar de escutar determinados movimentos pode-se deixar de lado reivindicações importantes que são feitas por outros grupos da sociedade civil.

Em se tratando da influência que as conferências nacionais possuem nas tomadas de decisão de políticas públicas, infere-se pelo depoimento do entrevistado $\mathrm{C}$ abaixo, representante da ANPED, que, em alguma medida, o governo percebeu a importância dessas entidades de participação social na discussão de formulação de políticas. Além disso, pelo mesmo depoimento, percebe-se que essa importância se deve ao fato de que os movimentos sociais, intitulados pelo entrevistado de associações, influenciam aquele meio com suas ideias de políticas mediante outros institutos de participação, como os fóruns, que já aconteciam antes de existir a Conae. Para o depoente, com a realização da Conae e FNE reconheceu-se uma situação existente. Segue abaixo, trecho do discurso do entrevistado C:

a gente tem uma força que vem do campo, vou te dar alguns exemplos. ANPED é uma
associação histórica, a ANPED tem uma criação induzida pelo governo, porque na década de
70 foi a própria CAPES que chamou os pesquisadores e disse: "Olha, precisamos ter
associações que se dediquem às várias áreas.". Então não há como desconsiderar o peso
político estratégico de negociação e, eu diria, mais especificamente, com a nossa associação,
porque ela tem uma penetração muito significativa nos programas de pós-graduação da
educação. Mas eu diria, que, na mesma medida, esses 3000 pesquisadores da educação hoje,
eles ocupam cargos de diretores de faculdades e centros de educação, eles assumem as pró-
reitorias muito mais ligadas à pesquisa e graduação dentro das universidades públicas e
também nas universidades privadas e comunitárias. Então eu acho que o peso e a relevância
da associação se revelam pela capacidade que os seus associados têm de influenciar por dentro
das instituições superiores e também nos órgãos colegiados, né, naquilo que é o fórum de pró-
reitores de graduação, com a nossa tentativa de levar à frente essa defesa da educação pública.
Acho que o Ministério da Educação reconhece essa força da associação na medida em que no
debate da composição para o Fórum Nacional de Educação, em um primeiro momento, por
portaria, entende um assento de representação das associações de estudos e pesquisas em
educação (ENTREVISTADO C, 2015).

Partindo-se dos objetivos que governo e movimentos sociais possuíam em relação à Conae, observou-se divergência a partir dos discursos de entrevistados dos dois grupos. Para o entrevistado F, representante do governo, a Conae serviu para legitimar as políticas já definidas anteriormente e mudanças incrementais foram acatadas. Esse discurso foi visto também nos depoimentos dos entrevistados $\mathrm{E}$ e G, representantes da SE/MEC e da SESU/MEC, respectivamente. Por outro lado, percebeu-se divergências nos discursos de representantes da sociedade civil sobre a redefinição de políticas, sobretudo em relação às políticas de ampliação de acesso que deveriam estar no Plano e consequentemente sobre a redefinição das políticas públicas de acesso ao ensino de nível superior. Fato este que, 
segundo entrevistado $\mathrm{C}$, representante da ANPED, não ocorreu. Houve uma manutenção das políticas existentes. Já para o entrevistado A, representante do CNE, a Conae e o PNE serviram para o Poder Executivo repensar o planejamento e gestão das políticas. Depreendese essa divergência dos depoimentos dos entrevistados F, C e A:

boa parte desse processo a gente tem que deixar isso claro, é um processo de legitimação, de legitimação das propostas que já estão, de certa forma, no ar. E de repente uma outra rejeitada, que ninguém mais fala nela. Mas quando eu comparo o que aconteceu nos últimos três anos, eu diria que o texto que foi aprovado no final é quase igual, quase igual (ENTREVISTADO F, 2015).

Então, quando a gente chega na Conae, a gente tem o conjunto de pesquisadores, professores e movimentos ligados à área sindical e estudantil, reconhecendo que houve um esforço federal. Por outro lado, é preocupante o modelo e a forma de transferência para inciativa privada, e esse debate aparece muito forte no colóquio que vai discutir a expansão privada a educação superior. E isso é uma preocupação que estava na Conae. Como reverter isso? Para reverter este quadro era fundamental que o governo assumisse pela Conferência e pelo Novo Plano, uma política de retomada da expansão pública da educação superior, essa era a questão que estava, eu diria que no centro do debate da Conae 2010 e nos acompanhou no processo de três anos e meio de tramitação do plano. Porque, no momento em que a lei, a 8.035, ela é apresentada pelo executivo no Congresso Nacional em dezembro de 2010, eu diria que nós fomos surpreendidos com o texto, que, em certa medida, desrespeitava do princípio básico da Conferência de 2010, que era o compromisso do governo federal e do financiamento público com a expansão do público. Isso em todas as etapas, níveis e modalidades, mas, na educação superior, a questão central, para nós, é que já havia sido colocado que os programas de estimulo e de ampliação de vagas na inciativa privada, eles deveriam ter um processo de revisão. [...]. Então, a gente tensão no debate da Conae com a SESU, era nós dizermos que PROUNI precisa ser programa provisório (ENTREVISTADO C, 2015).

O Plano Nacional de Educação ele é fundamental para que o MEC possa repensar o seu planejamento. Então nesse sentido para além do horizonte da participação social que foi efetiva, desenvolvendo conjuntos de discussões, de cobrar do Ministério ações concernentes ao próprio plano, não é, este movimento de participação ele resulta também em uma importante estratégia de gestão para o Ministério da Educação (ENTREVISTADO A, 2015).

Para Souza (2006), a capacidade limitada de se fazer mudanças substanciais nas políticas se percebe, sobretudo, quando se estuda a questão orçamentária. Sobre isso, tem-se que a discussão em torno da expansão do ensino superior e suas formas de financiamento da maneira como se apresentam hoje ainda deixam a desejar em relação ao que reivindicam alguns setores ligados à sociedade civil. Para o entrevistado C (2015), a discussão é feita, mas ela não consegue ser aceita em sua integridade. Isso por que há interesses de grandes conglomerados educacionais que estão em jogo. Daí, as políticas relativas à expansão do ensino de nível superior se mantém com alguns arranjos.

Apesar de os debates de movimentos sociais relativos à educação de nível superior terem se voltado para essa questão de expansão do ensino não houve uma revisão de 
programas ligados a essa temática. Para o entrevistado C (2015), a questão da expansão do ensino superior público foi o que moveu as discussões na Conae 2010, contudo, apesar de o esforço federal ser reconhecido pelos movimentos sociais - haja vista a criação de institutos federais em regiões fora dos grandes centros e do programa PROUNI - há a preocupação com a forma de transferência feita à iniciativa privada como forma de expandir o ensino de nível superior. A discussão que foi retomada na Conae girava em torno do processo de expansão do ensino de nível superior público. Isso implica desenhar uma política mais apropriada com as demandas da sociedade civil. O que aconteceu, segundo o relato do entrevistado C, representante da ANPED, é que o texto apresentado pelo executivo não considerou esse aspecto e reforçou o modelo de financiamento que já existia. Para o entrevistado B, também representante da sociedade civil, essas diferenças dos textos resultantes da Conae 2010 e daquele que foi apresentado ao Poder Legislativo foram superadas, em certa medida, pelas discussões na arena parlamentar. Seguem abaixo os depoimentos dos entrevistados C e B:

Porque, no momento em que a lei, a 8.035, ela é apresentada pelo executivo no Congresso Nacional em dezembro de 2010, eu diria que nós fomos surpreendidos com o texto, que, em certa medida, desrespeitava do princípio básico da Conferência de 2010, que era o compromisso do governo federal e do financiamento público com a expansão do público. Isso em todas as etapas, níveis e modalidades, mas, na educação superior, a questão central, para nós, é que já havia sido colocado que os programas de estimulo e de ampliação de vagas na inciativa privada, eles deveriam ter um processo de revisão. Se entendia a importância, ainda, naquele momento do PROUNI, mas era importante também entender que o financiamento tinha que ser direcionado para a ampliação das vagas públicas, e por isso é que o percentual entre vagas públicas e vagas privadas era uma tensão que se esperava que, na próxima década, se revertesse o quadro. A gente permanece com mais de $70 \%$ das vagas hoje ofertadas na educação superior, sendo assumidas. Eu diria: "Pela iniciativa privada", é entre aspas mesmo, porque, se você for olhar, no frigir dos ovos contanto exatamente qual é o investimento público na iniciativa privada hoje, para manter os alunos com bolsas PROUNI, ou para subsidiá-los com financiamento via FIES, o compromisso do recurso público, ele é absolutamente majoritário (ENTREVISTADO C, 2015).

Não estava tudo aquilo que nós queríamos sobre o documento final da Conae, mas ai fizemos o debate no congresso, tanto é que o projeto que vai bater o recorde de recebimento de emendas no congresso nacional, foram $2.900 \mathrm{e}$ poucas emendas (ENTREVISTADO B, 2015)

Também para o entrevistado A (2015), representante do CNE, as perdas nesse processo de formulação e definição de políticas relativas à expansão do ensino de nível superior abrange a destinação de recursos públicos para o pagamento de bolsas para a pósgraduação, por exemplo. Para esse entrevistado os recursos públicos devem ser destinados à educação pública. Esse discurso é comum a todos os representantes da sociedade civil. O que 
se percebe de diferente nos depoimentos é que há setores que sentem mais prejudicados do que outros com o não acatamento de mudanças na forma de financiamento.

Consoantes Santos (2008), essa discussão aponta, sobretudo para o debate acerca da Universidade Pública como um bem social e para a necessidade da sua ampliação e vivência, além de atender a programas de educação cujo objetivo principal é o de mercado. Segundo o autor, a Universidade do século XXI vivencia um impasse em definir quais são suas funções, se é a tradicional ou se adequar às novas.

Isso porque no contexto da globalização o conhecimento assume a função de força produtiva e isso representa uma divisão no mercado de trabalho, pois ele se subdivide em quem possui a informação e quem não a possui. Nesse cenário, o papel da Universidade é o de preparar a força de trabalho para o mercado existente (COSTA, 2011). O grande desafio da Universidade é, portanto, responder às demandas sociais num ambiente marcado por profundas desigualdades sociais

Considerando-se a finalidade propositiva das conferências, segundo aponta Souza (2012), esse papel foi cumprido pela Conae como afirma o discurso do entrevistado A e B, representantes da sociedade civil, que disseram que ao final havia uma proposta e indicações de políticas baseadas naquelas proposições. Esse mesmo discurso parte dos representantes do governo, E, F e G, que afirmam que o documento apresentado ao Congresso possuía propostas acordadas na Conae, entretanto os entrevistados E, F e G também concordam que esse documento proposto não contemplou todas as propostas advindas do documento final da Conae. Para sintetizar o pensamento dos representantes do governo, segue o discurso do entrevistado G (2015):

\footnotetext{
A proposta do PNE contemplou parcialmente as reivindicações, as posições, as deliberações da Conae. No Congresso Nacional, quando se abriu debate e aí nós tivemos audiências com ampla participação da sociedade, então a sociedade resgatou muitas propostas do documento da Conae e alterou o projeto original, que foi do Poder Executivo e conseguiram incorporar muitas deliberações da Conae no texto final do PNE. Foi um processo muito rico, não podemos dizer que alcançamos 100\%, mas o PNE está fortemente marcado pelas deliberações da Conae (ENTREVISTADO G, 2015).
}

Esse cenário corrobora com o afirmado por Saviani (2014) que diz que apesar de todo o esforço em se criar um ambiente onde se possa discutir ideias e propostas alguns grupos sabem que nesses espaços apenas se limitam a isso e, na verdade, é na arena parlamentar que as decisões são tomadas e é lá que grandes grupos atuam. Isto quer dizer que enquanto as conferências tentam pluralizar os grupos representantes da sociedade civil e 
discutir ideias, há pequenos grupos, porém importantes, que descartam essa possibilidade e atuam onde mais tem força e onde de fato podem ser tomadas decisões permanentes.

Apesar das perdas apontadas pelos entrevistados, a maioria concorda que o grau de influência da Conae nas deliberações finais do documento do PNE foi significativo. Eles apontaram os ganhos que esse processo provocou. Exemplo disso é que nos relatos os entrevistados viram grande importância de trazer a sociedade para discutir problemas, pois no PNE anterior isso não havia acontecido. Segundo o entrevistado B (2015), representante da sociedade civil, "você fazer uma inversão disso, você começar a discutir a política da base do outro lado, participando efetivamente, tendo um documento que teve a participação de representação".

Além do discurso de que a sociedade civil e a Conae enquanto espaço de discussão composta por representantes da sociedade civil no quesito educação, são importantes. Percebeu-se no discurso de todos eles os conflitos internos que ocorreram. Ora eles eram tratados como ganhos e perdas, ora eram tratados como embates. Se por um lado a sociedade civil tenta demonstrar que a forma de financiamento do ensino de nível superior deve ser replanejado, o governo tenta mostrar suas limitações, sejam elas de cunho orçamentário ou de limitação de execução de políticas ou simplesmente a janela de oportunidade não se abre naquele momento. Demonstrou-se também que o governo se atentou às novas propostas que conforme eles mesmos é interessante, pois alguns aspectos antes nunca vistos se tornaram evidentes a partir das discussões. Segundo relato do entrevistado F (2015), representante da SESU/MEC:

\begin{abstract}
A minha percepção é de que sempre é bom ouvi-los, ouvir a sociedade civil organizada e mais militante. Porque o que ela sempre põe é uma bandeira, um ela alerta a gente para coisas que às vezes a gente não se dá conta e dois, se ela vai um pouco além do que a gente pode ir, a gente tem uma oportunidade também de se contrapor não é, e dizer "Olha, isso é até possível, mas não é possível nesse momento, por isso, por isso e por isso". Então da para, é importante fazer a argumentação também, tem gente que quer o paraíso sem morrer, não é? Então é importante que a gente mostre que existe uma trajetória (ENTREVISTADO F, 2015).
\end{abstract}

Infere-se a partir desses relatos a ambiguidade que a democracia deliberativa apresenta e que é apontada por Gohn (2014): ela é fonte de pressão e precisa ao mesmo tempo responder a um ativismo propositivo, organizado e ordenado. Na prática, isso é resolvido ou pelo conflito ou pela construção coesa da sociedade civil.

Para Costa (2014, p. 186), "a ideia de acordos e de construção de consensos aparece como uma condição para superação de tensionamentos no confronto político". E essa 
condição de superação relaciona-se à nova forma de reivindicação dos movimentos sociais diante das possibilidades ofertadas pelo Estado democrático.

4.1.2.2 Aumento da influência da Conae na formulação de políticas de educação de nível superior

Quando perguntados sobre novas formas de otimizar a participação da sociedade civil na elaboração de políticas do ensino de nível superior, houve uma divisão clara dos dois grupos entrevistados. Aqueles que fazem parte do grupo dos representantes do governo afirmam que o que existe já é suficiente e se mostra como a fórmula perfeita para ter a sociedade civil contribuído na construção de políticas públicas de educação. Seguem relatos dos entrevistados F (2015), G (2015) e E (2015):

Não, acho que a forma que ela influencia já para mim está ótimo, eu acho que a Conae ela não substitui o PNE, a Conae é um grande gerador de ideias que podem ser utilizadas para criar programas e políticas para a educação (ENTREVISTADO F, 2015).

Não, acho que tudo que veio das conferências, municipal, estadual, estão lá, qualquer outra forma ficaria com o segundo Conae, o terceiro Conae. Em 2010 foi o primeiro. E ai qualquer coisa, qualquer coisa nova hoje, assim fora do PNE, tem que ser via projeto de lei, e ai a sociedade tem que influenciar o congresso para se transformar aquilo em lei (ENTREVISTADO G, 2015).

Olha, nós tivemos na Conae o que era acordo e tivemos o que era atuação pontual de cada entidade. O conjunto das entidades representam interesses diferentes, por exemplo, entre gestores e professores ou profissionais da educação, esses interesses são diferentes, então têm posições que as entidades atuavam diretamente. E aí através da mediação da Secretaria Executiva Adjunta, nós oportunizamos contatos, audiências, não só com o Ministério da Educação, com as Secretarias e com o Ministro, como também com o Parlamento. Tivemos oportunidade de tratar pontualmente algumas posições que eram de entidades. Eles tiveram oportunidade de colocar seu pleito (ENTREVISTADO E, 2015).

Nos dois primeiros depoimentos, a negativa fica clara nas respostas, entretanto ainda no segundo discurso o entrevistado acrescenta que qualquer nova forma de influência deve ser por meio do Poder Legislativo. A ideia que se extrai desse excerto é que com o Poder Executivo a participação da sociedade civil está completa e não há mais como aprimorar essas ações. Em adição a essa ideia, o terceiro trecho apresenta que a Secretaria Adjunta do MEC extrapolou suas funções, ajudando as entidades a participarem de audiências públicas também no âmbito do Poder Legislativo. 
Infere-se desses posicionamentos dos representantes do governo que o objetivo deliberativo da Conae foi cumprido. Sendo a Conferência, conforme Avritzer (2012), um espaço de construção de ideias, de produção de debates e de estabelecimento de agendas, o governo se viu protagonista participante desse processo e contribuiu nas discussões e disputas. Por conseguinte, ele considera que não há outras formas de otimizar a participação da sociedade civil além dessa em que se convoca e mobiliza os cidadãos a contribuir na construção de políticas.

Além disso, um aspecto apontado pelo depoimento do entrevistado G é que com o esgotamento da atuação do Poder Executivo em mobilizar a sociedade civil além do já realizado, Conae, só resta a esta última tentar influenciar na tomada de decisão do Poder Legislativo. Isso corrobora com o que Capella (1996) denominou de fluxo político. Nos momentos em que todos concordam, a mudança acontece, do contrário deve-se imprimir mais esforço para se conseguir que a ideia seja implementada. Isto quer dizer que quando o Poder Executivo vê sua atuação limitada, os esforços que a entidades devem fazer para validar suas ideias é maior. É importante deixar claro que o que se está definindo como limitador do Poder Executivo pode ser algo externo ou interno a ele e também pode ser tida inclusive como uma estratégia do próprio poder para se afastar de assumir determinados riscos.

Ao analisar esse aspecto sob a perspectiva da sociedade civil, os relatos dizem que há ainda outras formas de cooperação dela na formulação de políticas públicas. A exemplo disso, o entrevistado D (2015), representante do PROIFES, afirma que na fase em que se encontra o PNE II é interessante a articulação em torno do monitoramento das metas. Ademais, o entrevistado C (2015), representante da ANPED, atenta-se para um outro aspecto, qual seja, o de maior participação das entidades representantes da educação de nível superior nas conferências municipais e estaduais. Em complemento ao dito, segue na íntegra a fala do entrevistado C (2015), representante da ANPED:

Enquanto pesquisadores nós temos que ocupar as conferências municipais. Nós não podemos abrir mão de estar lá no debate das conferências estaduais. Porque o procedimento da s conferências já é um procedimento que tem uma capilaridade de escuta, que o documento referência, quando ele é elaborado, existe um mecanismo de avaliação dele na instancia municipal e intermunicipal e estadual nós podemos entrar com emendas aditivas, substitutivas, um novo texto e esse mecanismo é um mecanismo fundamental que é o lugar em que a gente precisa intervir em cada parágrafo, em cada conceito que está ali explicitado no documento referência, então o que eu diria é que o mecanismo está traçado, ele pode ser aperfeiçoado, a tecnologia hoje nos ajuda a chegar em uma conferência como nós chegamos nesse ano de 2014 , com o documento todo marcado, indicando página a página em cores diferenciadas de onde vinha aquela contribuição (ENTREVISTADO C, 2015) 
Isso demonstra que apesar de o mecanismo de conferências funcionar, as entidades da sociedade civil precisam refletir sobre sua atuação nos eventos de base. Considerando que a atuação dessas entidades se dá mais intensamente na conferência nacional e também informalmente por meio dos contatos com agentes do governo, é necessária mobilização nos municípios e estados para que se consiga propor mudanças nos programas formativos para os cursos de licenciatura. Essa discussão necessita estar presente nas conferências para que a função das universidades seja reelaborada e que ela influencie bem mais no processo de educação básica (ENTREVISTADO B, 2015).

O processo de ressignificação do papel que as universidades possuem na sociedade remete ao que falou Santos (2008) sobre a construção da Universidade como bem público, apresentando as forças sociais protagonistas desse embate e o sentido político atribuído aos seus desafios. Para esse autor, as três forças políticas - a sociedade politicamente organizada, a Universidade Pública e o Estado Nacional - devem ser bem definidas e se voltar para além da produção de conhecimentos gerais e para o atendimento da função mercadológica, deve alcançar a formação mais plural e democrática que atenda aos vários contextos sociais em que vivemos.

O entrevistado do CNTE, B (2015), contribui com outra fala ao afirmar que há que se criar a lei da gestão democrática. Nela é imperativo a criação de espaços deliberativos dentro das escolas e das universidades e outro aspecto seria a regulamentação do Sistema Nacional de Educação. Ele afirma que isso traria envolvimento da sociedade civil nos debates sobre educação.

Essa questão, para Dagnino (2002), remete ao debate de que a participação social é:

um processo de construção de identidade e aprendizado de gestão da vida coletiva, que se inicia com a convivência e tomada de decisões cotidianas, desde as questões mais simples até os processos complexos de administração de obras, de gestão dos recursos públicos e outras atividades relativas à implementação de programas e políticas públicas (DAGNINO, 2002).

Deste modo, a participação social vai além de sua normatização, pois esta depende do tipo de sociedade que há e seu amadurecimento quanto a esse tema e também do momento histórico em que se encontra. Mais do que uma reivindicação do Estado e de determinados setores da sociedade civil é importante que a sociedade como um todo se sinta mais pertencente ao processo de construção de uma política. A participação social se dá 
quando o direito à responsabilização da tomada de decisão é atribuída à sociedade. Não há simplesmente a consulta ao cidadão, há partilha de poder (DANIEL, 1994).

Cabe salientar, contudo, que um espaço institucionalizado de participação não é garantia de efetiva participação da sociedade civil, ele pode se caracterizar somente como um espaço onde a sociedade consegue se reunir e discutir sobre situações concretas vivenciadas pela população (TEIXEIRA, 2001).

Por conseguinte, quando o entrevistado diz que é importante desenvolver estratégias para que mais sujeitos ligados à educação discutam sobre seus problemas ou mesmo quando se fala da necessidade de capilarização das entidades de participação ligadas ao ensino superior, quer dizer que é necessário criar mais oportunidade de discussão com sujeitos que vivenciam experiências que podem ajudar a construir políticas melhores, permitindo-lhes vivenciar a partilha de poder e responsabilidade e não somente deixá-los como indivíduos passivos no processo de construção de políticas.

A contraposição de ideias do que seja participação social entre os dois grupos de entrevistados ficou evidente. Enquanto o governo acha que o que foi feito está suficiente, o outro grupo quer mais inserção, mais integração e maior gestão do poder. Nesse contexto, na seção seguinte será analisada a relação mantida entre o Estado e a sociedade civil no âmbito da Conae.

\subsubsection{Relação entre Estado e sociedade civil no âmbito da Conae}

Neste item analisou-se a dinâmica estabelecida entre governo e sociedade civil na Conae, a maneira como se relacionam e também como são construídas as estratégias de encaminhamento das proposições nas conferências e destas para a arena parlamentar. Nessa categoria serão usadas as entrevistas para entender como é a percepção de cada grupo referente à temática explicitada.

\subsubsection{Dinâmica entre governo e sociedade civil}

Nesse aspecto, tanto os representantes do governo como da sociedade civil enxergaram pontos de conflito na relação no decorrer da Conae e do Fórum Nacional de Educação. Ao se remeter ao PNE I (PNE 2001 - 2010), a relação governo e sociedade civil foi bastante tensa e os dois se enxergavam como rivais. Eles caminhavam separadamente. 
Esse cenário corrobora com o explanado por Lobato (2006) que acredita que por muito tempo as demandas da sociedade eram externas em relação ao processo de gestão de políticas. Elas só surgiam quando da negação da falta de ação do Estado. Elas só tinham espaço na agenda conforme as relações de interesses.

Na Conae 2010, percebe-se que algumas arestas foram reparadas, contudo há ainda alguns momentos de tensão e conflito. Essa palavra foi ressaltada em várias entrevistas, conforme depoimento de representante da SESU/MEC, G (2015), "é uma relação de mediação. É uma relação de conflito".

De um lado está o governo a quem compete gerir as políticas e do outro a sociedade que mostra suas demandas e exige esforço do governo para entendê-las e colocá-las em prática. Desse modo, o governo mostra o que pode ser viável da ótica da gestão e o que deve ser descartado. Segundo G (2015), “a gente até mostrava como que aquilo seria viável ou não viável”.

Apesar de a Conae e mesmo o FNE ser tido como espaços de democráticos e plurais de participação, de proposição, identifica-se nos depoimentos a percepção desses espaços como lugares de disputa e tensão. Os entrevistados B e C (2015), representante da sociedade civil, explicitam que mesmo no surgimento do FNE, após a Conae houve momentos de maior conflito, pois ele foi incialmente constituído por meio de Portaria do MEC decorrente do documento final da Conae e só ano passado que teve sua aprovação pela Lei 13.005/2014. Isso demonstra um pouco da fragilidade da constituição do FNE e, segundo o entrevistado C (2015), representante da ANPED, o governo e sociedade civil precisam fortalecer o vínculo para incentivar esses espaços de pactuação e diálogo. Ele ainda acrescenta de que forma as tensões aconteciam e como era a percepção do governo em relação aos pontos de conflito

\footnotetext{
Lá na conjuntura nossa de debate preparatório para a Conae, nós vivemos algumas tensões com SESU, mas ao mesmo tempo havia uma compreensão do próprio governo de que, o que a sociedade civil estava dizendo é: "Governo, defendemos a mesma causa. A ampliação de verbas para a educação brasileira, só que do nosso ponto de vista, essa ampliação precisa ser pública." Então, a gente tensão no debate da Conae com a SESU, era nós dizermos que PROUNI precisa ser programa provisório (ENTREVISTADO C, 2015).
}

Infere-se do trecho acima, conforme aponta Faria (2006), que os institutos de participação social se fundamentam na ideia de que as decisões ocorrem mediante debates e negociação. Os conflitos narrados pelos entrevistados fazem parte desse cenário, pois se constituíram como discussões abertas acerca da educação. Infere-se que pela metodologia 
adotada pela Conae o objetivo eram os debates e negociações entre os diversos grupos ali representados.

Para o entrevistado D (2015), representante do PROIFES, o papel dos representantes da sociedade civil é mostrar ao governo as incongruências. Ele começa afirmando que a relação da sociedade civil e governo é tranquila, contudo como o governo defende suas ideias e posições, o outro grupo deve ser um pouco mais incisivo em mostrá-lo as questões que importam. Segue trecho da entrevista:

Olha acho que é uma relação muito tranquila, evidentemente que o governo defende as posições de governo, então acho que o papel das entidades é um pouco no sentido de tentar mostrar as incongruências, às vezes um pouco às questões de certa forma equivocadas, como esse debate que está correndo sobre a questão da pátria educadora.

As convergências e divergências que ocorrem na relação entre Estado e sociedade civil nesses ambientes de democráticos de diálogos vão ao encontro do que afirma Gohn (2011):

os movimentos são o coração, o pulsar da sociedade. Eles expressam energias de resistência ao velho que oprime ou de construção do novo que liberte. Energias sociais antes dispersas são canalizadas e potencializadas por meio de suas práticas em "fazeres propositivos".

Ao se remeter aos conflitos colocados pelos entrevistados e sobre as disputas que ocorreram naquele ambiente, percebe-se que apesar de terem trazido representantes da sociedade civil para a arena de discussão, setores hegemônicos conseguem manter políticas que lhes interessam. Um exemplo disso é a questão da expansão das vagas das universidades. Dessa forma, programas de financiamento dos conglomerados provados ainda permanecem como políticas de educação superior. Isso mostra que a despeito da diversidade propagada pelo governo e setores ligados à sociedade civil, ainda há que rever se a sociedade civil está de fato tendo seus interesses representados.

Essa situação corrobora com o cenário apresentado por Wendhausen (2006) que afirma que pode ocorrer nesses espaços institucionalizados para participação social a subordinação deles pela gestão. A relação entre Estado e sociedade civil se baseia na submissão da segunda em relação à primeira e não na equidade. Isso pode provocar a aceitação de decisões de determinados grupos em detrimento da decisão coletiva.

A despeito dos conflitos, ambos, governo e representantes da sociedade, concordaram que houve também ganhos ou convergências de ideias. No dizer do entrevistado C (2015) "eu diria que em alguns momentos a sociedade civil avança, ela convence a sociedade política e em alguns momentos a sociedade política nos atropela”. É, portanto, uma relação de discordâncias e concordâncias. Para o entrevistado D (2015), "é uma relação muito 
tranquila". Observa-se com isso que a relação estabelecida entre governo e sociedade deve ser estreitada continuamente apesar dos conflitos. Nesse ponto todos os entrevistados foram unanimes. A dinâmica implementada pela Conae e mesmo pelo FNE logo em seguida trouxe a sociedade civil para mais próximo do governo, contribuindo para que algumas questões mais sensíveis fossem debatidas por grupos com interesses antagônicos. Isso por si só já se configura como um passo a frente do que ocorreu em outros momentos onde nem mesmo o debate entre grupos acontecia e, sobretudo, com o governo por perto.

A participação é efetiva quanto mais articulada ela está com a representação, seja para usá-la como arena de negociação, seja para ampliar a participação dos grupos. Em outras palavras, a relação Estado e sociedade deve sempre buscar espaços de diálogo e discussão com a sociedade civil e esta deve ter em seu rol de representantes diversidade suficiente para que as discussões sejam mais ricas e para que haja um menor distanciamento da sociedade do Estado.

Para Faria (2006), a participação social contribui para se estabelecer a democracia a partir do momento que interfere no processo decisório. Com essas observações, percebeu-se que a relação estabelecida entre sociedade civil e governo no espaço da Conae se mostrou efetiva de maneira geral, pois abrangeu a participação de diversos grupos. Entretanto ao observarmos a educação de ensino de nível superior houve um certo distanciamento de determinados grupos da sociedade, como os profissionais ligados à educação básica, que não participaram efetivamente das discussões, conforme relatado pelos entrevistados. Esse gargalo que se tem entre ensino superior e a educação básica ainda limita o ideal de participação democrática.

O engajamento da sociedade civil nas discussões referentes à educação de nível superior é um processo contínuo e que se aprimora com tempo. Mesmo que ainda haja percalços e que o envolvimento de outros grupos ainda não compõe efetivamente esse rol de grupos de discussão, mas já há avanços nisso, pois tem havido uma percepção dentro dos representantes da sociedade civil que enquanto não juntar a educação de nível superior e a educação básica problemas estruturais na formação de alunos irá ocorrer.

Além disso, pensa-se que a comunicação entre esses níveis de educação aproxima as universidades de realidades diversas de formação, abrindo espaços para novas formas de conhecimento e novas formas de pensar sobre o ensino. No dizer de o entrevistado B (2015) o distanciamento que ainda existe entre o nível básico e superior ainda é um entrave para se discutir novas formas de expansão da universidade. Para ele "nós temos sempre uma crítica de 
que a formação dos profissionais da educação e atualmente a formação dos professores, muitas vezes está muito distante das realidades das escolas públicas no nosso país".

Posta essa realidade, o entrevistado B (2015) acrescenta que:

a Conae que é de 2010, que só tem 5 anos é que traz ao primeiro momento essa junção, por isso que tivemos a dificuldade no primeiro momento. $\mathrm{O}$ choque de distanciamento que você tinha é como se precisasse debater, e a nossa insistência, a nossa construção, e a efetivação da segunda Conae de 2014, já diminuiu um pouco, garantiu mais presença desse profissional nas etapas municipais, o que eu vejo é que em 2018, vai melhorar mais ainda (ENTREVISTADO B, 2015).

A partir desse excerto do entrevistado pode-se inferir que a participação de outros grupos que também são afetados pelas políticas de ensino de nível superior deve aumentar nas próximas conferências, contudo ainda merece atenção especial, pois influencia no processo decisório, redefinindo a forma de gestão, conforme afirmou Perez (2009).

Por fim, as discussões relatadas aqui reforçam que a pesquisa sobre a influência da participação social a partir do estudo da Conae no Plano Nacional de Educação II deve perpassar sobre as relações e dinâmicas que permeiam os protagonistas desse processo. Os conflitos decorrentes dessa relação foram importantes para discutir e deliberar sobre importantes pautas da educação de nível superior, ainda que nem tudo estivesse contido no texto final. Além disso, esse estudo mostrou que o estreitamento de relação entre estado e município em relação ao ensino de nível superior ainda é precário e precisa ser trabalhado para as próximas conferências. 


\section{CONSIDERAÇÕES FINAIS}

A realização deste trabalho buscou contribuir para análise da influência da participação social na formulação de políticas públicas de ensino superior, considerando a construção do Plano Nacional de Educação 2014 - 2024 no âmbito da Conae. A Conae foi realizada em 2010 e foi precedida por conferências municipais, estaduais e pela do Distrito Federal, tendo estas últimas ocorridas no decorrer do ano de 2009. A Conae foi instituída com o objetivo de ser um espaço democrático onde se pudesse discutir sobre a educação nacional. Dela participaram diversas entidades ligadas à educação como um todo: Secretarias do Ministério da Educação, dirigentes estaduais e municipais de educação e Conselho Nacional de Educação. Para a coordenação do evento foi designada uma comissão organizadora constituída por 35 membros. Dentre eles estão representantes das secretarias do Ministério da Educação e de entidades da educação ligadas à sociedade civil.

Para tanto, partiu-se de um referencial teórico fundamentado dos conceitos de sociedade civil e sua relação com o Estado, movimentos sociais em educação, formulação de políticas públicas e, além disso, buscou-se entender a constituição da ideia sobre Planos Nacionais de Educação, fazendo um resgate histórico da educação no Brasil até os dias atuais.

A partir do referencial teórico, buscou-se entender a influência da participação social, sobretudo de movimentos ligados à educação, na elaboração de políticas da educação de nível superior construídas com base no II Plano Nacional de Educação. A maneira como as reuniões da Conae foram conduzidas e sua própria idealização já se encontra no rol de instrumentos de participação. A metodologia adotada nas reuniões permitiu que as discussões abrangessem diversos segmentos da educação e trouxessem diferentes grupos para a discussão de questões relevantes e que por vezes não se configuraram como problemas detectados pelos grupos gestores da educação.

Em se tratando do ensino de nível superior, pode-se dizer que os debates ocorreram mais no âmbito federal o que mostra que ele ainda é pouco relevante no âmbito municipal e estadual e se encontra distanciado dessa realidade mesmo considerando que uma boa formação de profissionais da educação básica deve passar por uma boa formação de nível superior como encontrado na literatura referenciada nas seções anteriores. Apesar disso, as metas 15 e 16 do PNE II abordam essa questão de formação de profissionais da educação básica. Isso demonstra que há uma preocupação em mudar essa separação que existe entre os níveis educacionais. 
Para fins desse trabalho, optou-se por utilizar a análise de documentos relacionados à constituição da Conae e também dos documentos resultantes dessas reuniões. Dessa forma, foram estudados portarias, atas das reuniões e documentos de referência-base e referência-final da Conae. Em adição a isso, foram realizadas entrevistas semiestruturadas que apresentaram os depoimentos de representantes do governo e sociedade civil. O roteiro de entrevistas foi elaborado em consonância com as categorias definidas baseadas nos objetivos específicos. As três categorias analisadas permitiram desenhar a maneira como os protagonistas da sociedade civil e representantes do governo se relacionaram e como as políticas de educação de nível superior foram elaboradas. Finalmente, verificou-se de que forma a sociedade civil impacta na formulação dessas políticas.

Para atender o primeiro e o segundo objetivos específicos foi necessário analisar documentos que relacionassem os participantes da Conae, tanto os representantes da sociedade civil como os do governo. Ademais, as entrevistas permitiram avaliar a forma de participação desses protagonistas. Os terceiro e quarto objetivos específicos foram contemplados, respectivamente, nas categorias b e c. Esse estudo incluiu a análise das janelas de oportunidade baseada na teoria de John Kingdom e o estudo da institucionalização da Conae como meio de participação da sociedade civil. Ao longo da análise, foram feitas sugestões de melhoria da participação da sociedade civil na elaboração de políticas de educação de nível superior.

Do estudo por categoria permitiu-se depreender que apesar de a Conae ser um local onde se discute problemas e questões sobre a educação, em relação ao ensino de nível superior, as propostas apresentadas por essa conferência foram, sobretudo, elaboradas por um representante do Conselho Nacional de Educação que possui contato com representantes da sociedade civil e que participaram de forma indireta na elaboração do texto do documento referência. Isso permite dizer que alguns pontos foram discutidos fora do contexto Conae. Foi constatado que as políticas e programas permaneceram os mesmos e o estabelecimento de metas, mesmo nos casos de ampliação, não afetaram as estruturas dos programas. Isso pode ser percebido ao verificar que programas como FIES e PROUNI, relacionados à expansão do ensino de nível superior financiados com recursos públicos, porém destinados a instituições privadas, ainda continuam a existir no mesmo formato. Isso leva a concluir que as instituições privadas de ensino possuem grande influência na definição de políticas.

Observou-se que apesar de o financiamento não ter sido priorizado para as instituições públicas de ensino, houve a previsão de expansão do ensino de nível superior das instituições públicas em $40 \%$. Isso quer dizer que novas vagas devem surgir nas universidades 
públicas e a ampliação tanto estrutural quanto pedagógica pode ser realizada. Outro aspecto de fundamental importância é a preocupação de juntar dois níveis de ensino: o da educação básica com a de nível superior. Exige-se na meta 15 e 16 a previsão de qualificar os profissionais da educação básica

No que diz respeito à maneira como as reuniões foram conduzidas e sobre a definição dos atores participantes, percebeu-se que os protagonistas selecionados já haviam participado de outros encontros cujo objetivo era discutir e expor ideias em um ambiente democrático e que essas ideias pudessem compor uma agenda de governo. Sendo assim, com a experiência já vivenciada por eles foi possível utilizar metodologias que ajudassem nos debates e na sugestão de propostas viáveis de formulação e execução. A organização das conferências em etapas estaduais e municipais permitiu que indivíduos com as mais diversas realidades pudessem expor suas questões e trazer à tona problemas desconhecidos por quem é responsável pela formulação de políticas.

A metodologia aplicada caracterizou-se por ser um sistema integrado de deliberação em que a aprovação do texto só faria parte do documento da etapa estadual se fosse aprovado por maioria simples e por no mínimo cinco estados da federação. O mesmo aconteceu na etapa estadual para a nacional. Essa forma de tratar as propostas produzidas nos debates considera as questões tratadas desde o menor núcleo da federação e traz características de um debate democrático em que diversos atores participam e contribuem para alcançar o objetivo daquela conferência.

Um aspecto negativo e que dificulta a condução de reuniões, sobretudo em se tratando dos representantes governamentais, é que há grande rotatividade de pessoas e houve casos em que mesmo os substitutos apresentaram outros substitutos. A consistência de planos e ideias pode ser alterada em razão disso. Essa descontinuidade é prejudicial caso os atores de um mesmo grupo não estejam muito bem sincronizados. No caso da educação de nível superior, as reuniões de formulação do documento-base e da definição das diretrizes da Conae foram marcadas, em alguns momentos, pela ausência de pessoas da área da secretaria do MEC. Em relação a outras secretarias do MEC, há uma dinâmica de funcionamento diferente com o ensino superior. $\mathrm{O}$ texto que foi enviado para debate nas etapas municipais e estaduais, além do texto final, foi elaborado de forma diferente dos demais. O documento apresentado foi construído por apenas um indivíduo conselheiro do Conselho Nacional de Educação que possuía estreita relação com outros grupos da sociedade civil, representando um conjunto de interesses, e apesar de outros grupos da sociedade civil terem sido consultados pela relação 
estabelecida entre eles, o trâmite estabelecido previamente não ocorreu e isso pode gerar perdas.

Adicionalmente a esse fato, inclui-se o problema histórico de não se discutir sobre o ensino superior nos outros entes federativos (estados e municípios). Percebeu-se nas entrevistas que há uma clara divisão entre esses níveis e com base nas experiências anteriores se vem trabalhando para descentralizar as discussões em torno do ensino de nível superior e levá-las aos outros atores que se veem distantes dessa realidade. Esse aspecto também prejudica os debates em torno de melhorias nas políticas de educação de nível superior que acaba por se tornar restrito a grupos já historicamente estabelecidos e empobrece a discussão em torno de aprimoramentos a serem feitos na educação básica e que devem ser estruturados no nível superior.

Em relação à questão da formulação de políticas a partir do texto apresentado pela Conae, mesmo considerando todo o fluxo pelo qual esse documento passou referente às modificações sofridas no decorrer de seu trâmite na Conferência, alguns pontos do documento final não foram acatados no texto apresentado pelo Poder Executivo ao Legislativo. Isso implica dizer que algumas propostas decididas pela sociedade civil não foram acatadas pelo governo. Foram retomados os debates acerca delas somente na arena parlamentar. Isso configura a Conae como um espaço em que se debate e discute e se delibera, mas há questões de política e gestão que não permitem que o decidido na Conae seja apresentado ao Congresso. Isso não quer dizer que a Conae não contribuiu para a formulação de políticas. Ela possuía um forte caráter deliberativo, fato este certificado pelos entrevistados que afirmaram ter havido debate de ideias sem que a vontade do governo prevalecesse sempre. Isso demonstra que a Conae se configurou como um encontro entre sociedade e governo que definiu elementos que compuseram o desenho de políticas públicas da educação de nível superior.

Esse cenário leva a análise da relação estabelecida entre o Estado e a sociedade civil. De acordo com os entrevistados, tanto representantes do governo quanto da sociedade civil, concordaram que os papeis de ambos estavam delimitados e bem definidos. De um lado, o governo possuía a atribuição de organizar e financiar as conferências, e, do outro, a gestão dos debates ficou sob a responsabilidade da sociedade civil. Também era consenso que os conflitos ocorridos nos debates faziam parte daquele contexto e todos os grupos conseguiam se expressar e ouvir os argumentos do outro. Os embates eram previstos e solucionados naquele ambiente. Para isso, a metodologia adotada foi de importância relevante, pois permitiu que as disputas nos debates resultassem em acordos. Houve ganhos e perdas, como 
colocaram os entrevistados, mas se entende que a relação entre governo e sociedade na Conae contribuiu para preencher a lacuna que existe entre as decisões da Conferência com a forma de gestão.

A principal limitação deste trabalho consiste na não análise em profundidade das discussões na arena parlamentar, pois os embates e debates travados nesse espaço foram importantes para a construção do texto da Lei do PNE II e contribuem com informações relevantes que podem ser usadas na análise de participação social na elaboração do PNE II, tendo em vista que grupos da sociedade civil participaram das audiências públicas e dado o grande número de emendas propostas.

Para pesquisas futuras novos estudos poderiam ser realizados nas conferências municipais e regionais para se ter uma avaliação mais abrangente das situações dessas conferências. Outro ponto importante é que se poderia estudar e avaliar o Fórum Nacional de Educação fruto da Conae para melhor compreender as relações ali desenvolvidas e sua influência na elaboração e implementação das políticas de educação, considerando que ele se ocupa de avaliar as metas desenhadas no PNE II. Poderiam ser analisados aspectos relacionados à gestão das políticas de educação do ensino de nível superior, verificando em que medida o FNE e a Conae avaliam as políticas nacionais de educação e de que forma a execução dessas políticas constroem subsídios para aprimorar e reforçar a participação social sobre a gestão pública.

\section{Proposta de Intervenção}

Esta dissertação prevê a apresentação de uma proposta de intervenção baseada nos resultados da pesquisa. Vale ressaltar que a intenção é que cada recomendação seja discutida com a Secretaria de Articulação com os Sistemas de Ensino (SASE/MEC) como resultado de uma pesquisa científica desenvolvida no âmbito do Mestrado Profissional em Administração Pública do Programa de Pós-Graduação em Administração da Universidade de Brasília. Esta Secretaria se ocupa atualmente por desenvolver a coordenação das ações para a criação do Sistema Nacional de Educação e acompanhamento dos Planos de Educação. Ela foi criada em 2011 como uma demanda da Conae 2010. As recomendações poderão ser discutidas também com a SESU e as comissões da Conae e do FNE.

Propõe-se a elaboração de instrumentos internos de articulação de mobilização entre sociedade civil e Estado, sobretudo, dentro das conferências estaduais e municipais em se tratando da educação de nível superior. Esse instrumento deve se basear em dois aspectos: 
comunicação e mobilização. Para a comunicação poderia-se trabalhar o desenvolvimento de ações de divulgação das atividades das conferências por meio de mídias eletrônicas e redes sociais. Em relação à mobilização, sugere-se que se façam reuniões itinerantes nas municipalidades para conversar com instituições e grupos da sociedade civil que podem contribuir nas conferências. Dessa forma, se promoveria a capilarização das ações da Conae, promovendo a participação de diversos grupos.

Seria importante envolver outros atores para evitar que as discussões se restrinjam a determinados grupos. Além disso, o acompanhamento das deliberações da conferência nacional deveria ser feita para além do Ministério da Educação. Ela poderia ser realizada também por quem contribuiu com a elaboração do Plano Nacional de Educação. Para isso, além do instrumento de acompanhamento desenvolvido pela SASE, sugere-se que os entes desenvolvam mecanismos de acompanhamento de suas metas como forma de monitorar a implementação das políticas. Esse mecanismo ajudaria os entes a entenderem os gargalos da execução das políticas bem como poderia possibilitar melhorias.

O último ponto diz respeito à avaliação das conferências. Propõe-se, com base nas sugestões dos entrevistados, que se desenvolva um procedimento de avaliação das conferências, contendo informações sobre os atores dos eventos e a forma como ela foi desenvolvida e conduzida. Essa avaliação teria como finalidade, além de correção dos processos, promover e aprimorar ainda mais a participação social, considerando que, uma vez tornada pública, a avaliação poderia estimular a participação social de outros setores da sociedade. 


\section{REFERÊNCIAS}

ABRUCIO, F. L. ; COSTA, Valeriano Mendes Ferreira . Reforma do Estado e o Contexto Federativo Brasileiro. São Paulo: Fundação Konrad Adenauer, 1998. v. 12. 187 p.

AVRITZER, Leonardo. Conferências Nacionais: Ampliando e redefinindo os padrões de participação social no Brasil. Disponível <http://www.ipea.gov.br/participacao/images/pdfs/td_1739.pdf>. Acesso em 17 mai. 2014.

Sociedade civil e participação no Brasil democrático. In: AVRITZER, L. (Org.). Experiências nacionais de participação social. Belo Horizonte: Cortez, 2010.

AZEVEDO, J. M. Lins de. Reflexões sobre políticas públicas e o PNE. Revista Retratos da Escola, v. 4, n. 6, p. 27-35. 2010.

BOAVEnturA, S. S. Pela Mão De Alice: O Social e o Político na Pós- Modernidade. Ed. Cortez. São Paulo, 1997.

BOLlmanN, Maria da Graça N. Revendo o Plano Nacional de Educação: proposta da sociedade brasileira. Educ. Soc., Campinas, v. 31, n. 112, p. 657-676, jul.-set. 2010. Disponível em <http://www.cedes.unicamp.br>. Acesso em 25 jun. 2014.

BRANDÃO, Carlos Fonseca. PNE passo a passo: (Lei $n^{\circ}$ 10.172/2001): discussão dos objetivos e metas do Plano Nacional de Educação. São Paulo: Avercamp, 2006.

BRASIL. Ministério da Educação. Conferência Nacional de Educação (CONAE). Construindo o Sistema Nacional Articulado de Educação: o Plano Nacional de Educação, diretrizes e estratégias; Documento Final. Brasília, DF: MEC, 2010. Disponível em: <http://portal.mec.gov.br/Conae>. Acesso em: 13 jun. 2015.

Ministério da Educação. Conferência Nacional de Educação (CONAE 2010).

Construindo o Sistema Nacional Articulado de Educação: o Plano Nacional de Educação, Diretrizes e Estratégias de Ação. Documento Final. Brasília - DF, 2010. 
Ministério da Educação. Conferência Nacional de Educação (CONAE 2010). Documento Base. Brasília - DF, 2010.

BRASIL. Plano Nacional de Educação 2011-2020. Projeto de Lei Aprovado pela Comissão de Especial PL 8035/10. Câmara dos Deputados. Disponível em: $<$ http://www2.camara.gov.br/atividade-legislativa/comissoes/comissoes temporarias/especiais/54a-legislatura/pl-8035-10-plano-nacional-de educacao/arquivos/apresentacao-parecer>. Acesso em 2 jun. 2014.

- Censo da Educação Superior 2008: Dados Preliminares. Disponível em: <http://download.inep.gov.br/download/censo/2008/resumo_tecnico_2008_15_12_09.pdf>. Acesso em 25 nov. 2014.

Censo da Educação Superior 2012: Resumo Técnico. Disponível em: <http://download.inep.gov.br/download/superior/censo/2012/resumo_tecnico_censo_educaca o_superior_2012.pdf>. Acesso em 25 nov.2014.

Coordenação de Aperfeiçoamento de Pessoal de Nível Superior (Capes). Instituto Internacional para a Educação Superior na América Latina e no Caribe IESALC . $<$ http://biblioteca.planejamento.gov.br/biblioteca-tematica-1/textos/educacao-cultura/texto-6 2013-a-educacao-superior-no-brasil.pdf>. Acesso em 14 dez. 2014.

Conferência Nacional de Educação. Documentos. Brasília, DF: MEC. Disponível em: $<$ http://Conae.mec.gov.br/index.php?option=com_content $\& v i e w=$ category\&id=38\&Itemi d=5>. Acesso em 14 set. 2015.

Câmaras dos Deputados. Projeto de Lei 8035/2010. Aprova o Plano Nacional de Educação para o decênio 2011-2020 e dá outras providências. Brasília 2014. Disponível em: <http://www.camara.gov.br/proposicoesWeb/fichadetramitacao?idProposicao=490116> Acesso em 15 out. 2014.

Câmara dos Deputados: Projeto de Lei Plano Nacional de Educação 2011/2020. PL no 8.035/2010. Comissão de Educação e Cultura. Edições Câmara, Brasília - DF, 2011. (Série ação parlamentar). 
BUCCI, Maria Paula Dallari. Políticas públicas e direito administrativo. Revista de Informação Legislativa. Brasília a. 34 n. 133 jan./mar. 1997

CAMPOS, J.C.D. \& DINIZ, M.A. O Acesso à Educação na Ordem Constitucional Brasileira: a Consolidação da Cidadania no Estado Democrático de Direito.

CAPELlA, Ana Cláudia N. Perspectivas Teóricas sobre o Processo de Formulação de Políticas Públicas. Revista Brasileira de Informação Bibliográfica em Ciências Sociais. São Paulo: ANPOCS, 1996.

CARDOSO, R. A trajetória dos movimentos sociais. In: DAGNINO, Evelina, Org. Anos 90 Política e Sociedade no Brasil. São Paulo: editora Brasiliense. 1994. p. 81 - 90.

CASTRO, Jorge A. Financiamento da Educação e Desenvolvimento. Brasília. Ipea. 2011.

CHESNAIS, François. A Mundialização financeira: gênese, custos e riscos. São Paulo: Xamã, 1998.

COSBY, Paul. C. Métodos de Pesquisa em Ciências do Comportamento. São Paulo: Atlas, 2014.

COSTA, A. M. M. Movimentos Sociais e Educação Superior: ação coletiva e protagonismo na construção do plano nacional de educação (2014-2024). Tese. Doutorado em Ciências Sociais. Universidade Federal do Rio Grande do Norte, Natal, 2014.

CRESWELL, John W. Projeto de Pesquisa: métodos qualitativo, quantitativo e misto. Porto Alegre: Artmed, 2010.

CUNHA, Eleonora Schettini M. Conferências de Políticas Públicas e Inclusão Participativa. Brasília: IPEA, 2012.

CUNHA, L. A. O Ensino Superior no octênio FHC. Campinas. Educação e Sociedade. v. 24, n. 82, abr, 2003. 
DAGNINO, Evelina. Sociedade Civil, Espaços Públicos e Construção Democrática no Brasil: Limites e Possibilidades. In: DAGNINO, Evelina (Org). Sociedade Civil e Espaços Públicos no Brasil. São Paulo: Paz e Terra, 2002.

DANIEL, Celso. Gestão Local e Participação da Sociedade. Revista Polis, São Paulo, n.14, p.21-41. Disponível em: < http://www.polis.org.br/uploads/1098/1098.pdf>. Acesso em: 12 mar. 2015.

DYE, Thomas R. Understanding Public Policy. 14 ed. Universidade Cornell: Prentice HAll, 2014.

DEITOS, Roberto Antonio. Políticas públicas e educação: aspectos teórico-ideológicos e socioeconômicos. Acta Scientarium. Education. Maringá, v. 32, n. 2, p. 209-218, 2010.

DOURADO, L. F. Plano Nacional de Educação antecedentes históricos, avaliação e perspectivas. In: DOURADO, L. F. (org.). Plano Nacional de Educação (2011-2020): avaliação e perspectivas. 2. ed. Belo Horizonte: Autêntica, 2011, p. 17-60.

DUARTE, J. Entrevista em profundidade. In: DUARTE, J.; BARROS, A. (org.). Métodos e técnicas de pesquisa em comunicação. São Paulo: Atlas, 2005.

FARIA C. F. Fóruns participativos, controle democrático e a qualidade da democracia no Rio Grande do Sul:a experiência do governo Olívio Dutra (1999-2002). Opinião Pública, Campinas, vol. 12 , n 12 , p. 378-406, Novembro, 2006.

FARIA, C. F.; SILVA, V. P.; LINS, I. L. Conferências de políticas públicas: um sistema integrado de participação e deliberação? Revista Brasileira de Ciência Política, $\mathrm{n}^{\circ} 7$, janeiro abril de 2012, pp. 249-284. Brasília, 2012.

Participação e deliberação nas conferências de saúde: do local ao nacional. In: Conferências Nacionais: atores, dinâmicas participativas e efetividade. AVRITZER. L.; SOUZA, C. H. L (orgs.). IPEA, 2013. 
FARIAS, B. P. M. A dinâmica do Conselho Nacional da Juventude - CONJUVE e o campo das políticas públicas educacionais. Dissertação de Mestrado. Universidade de Brasília, 2013. Disponível em: http://hdl.handle.net/10482/15728. Acessado: 10 set.2015.

FARIAS FILHO, Milton Cordeiro. Planejamento da pesquisa científica. São Paulo: Atlas, 2013.

FERNANDES, F. C. A conferência nacional de educação: construção democrática de políticas de estado. Disponível em: http://conae.mec.gov.br/images/stories/pdf/texto\%20chagas\%20alterado25.03.pd f. Acesso em 12 jan, 2015.

GERMANO, Jose Willington. Estado Militar e Educação no Brasil (1964 - 1985). 5. ed. São Paulo: Cortez, 2011.

GOHN, Maria da Glória. Novas Teorias dos Movimentos Sociais. 5.ed. São Paulo:Edições Loyola, 2014.

Movimentos sociais e redes de mobilização no Brasil contemporâneo. Petrópolis: vozes, 2010.

Movimentos Sociais e Educação. 8.ed. São Paulo: Cortez, 2012.

\section{Movimentos Sociais na Contemporaneidade. Disponível em:} <http://www.scielo.br/pdf/rbedu/v16n47/v16n47a05.pdf> . Acesso em 7 out, 2014.

GOUVEIA, A. B.; SOUZA, A. R. de. Perspectivas e desafios no debate sobre financiamento e gestão da educação: da Conae a um novo PNE. Educ. Soc., Campinas, v. 31, n. 112, p. 789-807, Set. 2010.

HABERMAS, Jürgen. Direito e Democracia: entre faticidade e validade. v.II. Rio de Janeiro: Tempo Brasileiro, 2003. 
HAM, Christopher e HILL, Michael. O processo de elaboração de políticas no estado capitalista moderno. Londres, 1993, $2^{a}$ edição. Traduzido por Renato Amorim e Renato Dagnino.

HILL. Michael. Implementação: uma visão geral. In: SARAVIA, Enrique.; FERRAREZI, Elisabete. (orgs). Políticas Públicas: coletânea. Brasília: ENAP, 2006. vol. 2

HORTA, J. S. B. Plano Nacional de Educação, da Tecnocracia à Participação Democrática. In: CURY, C. R. J.; HORTA, J. S. B.; BRITO. V. L. A. Medo à Liberdade e compromisso democrático: LDB e Plano Nacional de Educação. São Paulo: Editora do Brasil, 1997, p. 137-206.

HOWLETT, Michael Patrick. Studying Public policy: policy cycles and policy subsystems. 1995 oxford University Press, New York.

HÖFLING, Eloisa de Mattos. Cadernos Cedes, ano XXI, nº 55, novembro/2001.

LEROUX, S. O. Deliberando sobre La democracia deliberativa. Los dilemas de Lal deliberación pública. Acta republicana - Politica y Sociedad, Guadalajara, México, ano 5, n5 (2006) 53-64.

LINDBlOM, Charles E. O Processo de Decisão Política. Trad. De Sérgio Bach. Brasília. Editora Universidade de Brasília. 1981.

LOBATO, Lenaura. Algumas Considerações Sobre A Representação De Interesses No Processo De Formulação De Políticas Públicas. In: SARAVIA e FERRAREZI (Orgs). Políticas Públicas: coletânea. Brasília: ENAP, 2006. vol. 2

MILITÃO, S.C, PERBONI, F. MILITÃO, A.C. Novo PNE (2011-2020): Convergências e Divergências. I Seminário internacional de Representações Sociais, Subjetividade e Educação. Disponível em <http://educere.bruc.com.br/CD2011/pdf/5866_3463.pdf>. Acesso em 25 jun. 2014.

MONTEIRO, Jorge Vianna. O Processo Decisório de Política. In: SARAVIA e FERRAREZI (Orgs). Políticas Públicas: coletânea. Brasília: ENAP, 2006. vol. 1 
OLIVEIRA, D. A. A gestão democrática da educação no contexto da reforma do estado. In: FERREIRA,Naura Syria Carapeto (Org.) Gestão da educação: impasses, perspectivas e compromissos. São Paulo: Cortez, 2006. p. 91-112.

PINTO, C. R. J. As conferências nacionais no governo Lula: limites e possibilidades da construção de uma esfera pública. In: ENCONTRO ANUAL DA ANPOCS, 30. Anais. Caxambu, out. 2006.

POCHMANN, Márcio. Financiamento da Educação e Desenvolvimento. Brasília. Ipea. 2011.

POGREBISCHI, T. Conferências Nacionais e Políticas Públicas para Grupos Minoritários. In: Conferências Nacionais: atores, dinâmicas participativas e efetividade. AVRITZER. L.; SOUZA, C. H. L (orgs.). IPEA, 2013.

PEREZ, MARCOS AUGISTO. A administração pública democrática: institutos de participação popular na administração pública. 1. ed. Belo Horizonte: Fórum, 2009.

ROCHET, J E PRADO, A.P. Educação e Diversidade Cultural. Texto Preparatório. Brasília, 2010.

SAMPAIO, H. Ensino Superior no Brasil - o setor privado. São Paulo, Hucitec, 2000.

SANTOS, L. L. Diretrizes Curriculares Nacionais para o Ensino Fundamental de 9 anos e o Plano Nacional de Educação: abrindo a discussão. Educ. Soc., Campinas, v. 31, n. 112, p. $833-850$, jul.-set. 2010 .

ALMEIDA FILHO, Naomar. A Universidade no Século XXI: para uma universidade nova. Coimbra, 2008.

SARAVIA, Enrique. Introdução à Teoria da Política Pública. In: SARAVIA e FERRAREZI (Orgs). Políticas Públicas: coletânea. Brasília: ENAP, 2006. vol. 1. 
SAVIANI, Demerval. Plano de Desenvolvimento da Educação: Análise crítica da política do MEC. - Campinas, SP: Autores Associados, 2009.

Sistema Nacional de Educação e Plano Nacional de Educação: significado, controvérsias e perspectivas. - Campinas, SP: Autores Associados, 2014.

Sistema Nacional de Educação articulado ao Plano Nacional de Educação. Abertura do Simpósio de Abertura da Conferência Nacional de Educação (CONAE 2010). Brasília, 29 de março 2010. Revista Brasileira de Educação. v. 15, n. 44, p. 393-380

Florestan Fernandes e a Educação. Estudos Avançados. v. 10, n. 26. São Paulo: jan./abr. 1996.

SEIDMAN, I. (1998). Interviewing as qualitative research: A guide for researchers in education and the social sciences (2nd ed.). New York: Teachers College Press

SGUISSARDI, Valdemar. Modelo de Expansão da Educação Superior no Brasil: predomínio privado/mercantil e desafios para a regulação e formação universitária. http://www.scielo.br/pdf/es/v29n105/v29n105a04.pdf.

SOUZA, Clóvis Henrique Leite de. A que vieram as Conferências Nacionais? Uma análise dos objetivos dos processos realizados entre 2003 e 2010. Brasília: IPEA, 2012.

TEIXEIRA, Elenaldo Celso. O local e o global: limites e desafios da participação cidadã. São Paulo: Cortez; Recife: EQUIP; Salvador: UFBA, 2001.

TEIXEIRA, Elenaldo Celso. O papel das políticas públicas no desenvolvimento local e na transformação da realidade. Disponivel em: <http://www.fit.br/home/link/texto/politicas_publicas.pdf>. Acesso em: 12 dez. 2014.

TELLES, Vera da Silva. Direitos sociais: afinal do que se trata? Belo Horizonte: UFMG, 1999.

TOURAINE, A. Les mouvements sociaux. In: TOURAINE, A. Production de la société. Paris: Éditions du Seuil, 1973, p. 347-389. 
VIEIRA, M.M.F. Por uma boa pesquisa qualitativa em administração. In. VIEIRA, M.M.F.; ZOUAIN, D. M. Pesquisa Qualitativa em Administração. Rio de Janeiro:FGV, 2005.

WENDHAUSEN, Águeda. L. P, BARBOSA, Tatiane Muniz, BORBA, Maria Clara de. Empoderamento e Recursos para a participação em Conselhos Gestores. In: Saúde e Sociedade v. 15, n. 3, p. 131-144, set-dez 2006. 


\section{ANEXO I \\ ROTEIROS DE ENTREVISTAS SEMI-ESTRUTURADAS}

\section{A) ROTEIRO DE ENTREVISTAS PARA REPRESENTANTES DA SOCIEDADE CIVIL DAConae}

1) Quais os tipos de atividades e ações desenvolvidas pelas conferências? (categ. 1)

2) Como é a dinâmica de trabalho da conferência? São feitas apenas reuniões periódicas ou há outros espaços de discussão e decisão? (categ.1)

3) Como as prioridades de ação são definidas ou sugeridas?(categ.1)

4) Como funciona o processo de deliberação? (categ.1)

5) Há alguma estratégia para encaminhar as deliberações das reuniões aos órgãos gestores?(categ.1)

6) Como foi o processo de discussão do documento/texto-base no âmbito da delegação/grupo que preparou as deliberações finais?(categ.2)

7) É possível identificar contribuições da sociedade civil na formulação das políticas relativas ao ensino de nível superior?(categ.2)

8) É possível que a Conae tenha outras formas de influenciar na polític de educação de nível superior?(categ.2)

9) Qual o grau de influência do Conae nas deliberações finais do PNE II? Por quê?(categ.2)

\begin{tabular}{|c|c|c|c|}
\hline Alto & Médio & Baixo & Nenhum \\
\hline
\end{tabular}

10) Como se dá a relação com a Secretaria de Educação Superior - SESU?? (categ.3)

11) Haveria alguma sugestão de mecanismo ou forma de atuação para otimizar a participação da sociedade civil na Conae relativo à formulação de políticas de educação de nível superior?(categ.2)

\section{B) ROTEIRO DE ENTREVISTAS PARA REPRESENTANTES DA SESU/MEC}

1) Qual a definição do MEC para a Conae? (categ. 1)

2) Qual o objetivo do MEC para a Conae?(categ. 1)

3) ) Como foi a participação da SESU/MEC na comissão organizadora da Conae?(categ. 2)

4) Como avalia a relação da SESU/MEC com a sociedade civil?(categ. 3)

5) A Conae pode ser considerada mecanismo de participação social para a formulação das políticas de educação referentes ao ensino superior? (categ.2)

6) Quais instrumentos o MEC utiliza para acompanhar as ações da Conae?(categ. 2)

7) Qual o grau de importância atribuído à atuação da sociedade civil na formulação de políticas de educação de nível superior?(categ. 2)

8) Haveria alguma sugestão de mecanismo ou forma de atuação para otimizar a participação da sociedade civil na formulação de políticas de educação nível superior?(categ. 2)

9) É possível identificar na Conae outras formas de influenciar nas políticas de ensino de nível superior?(categ. 2)

10) Como foi o processo de discussão do documento/texto-base no âmbito da delegação/grupo que preparou as deliberações finais?(categ. 2)

11) Qual o grau de influência da Conae nas deliberações finais do PNE? Por quê?(categ.2)

\begin{tabular}{|c|c|c|c|}
\hline Alto & Médio & Baixo & Nenhum \\
\hline
\end{tabular}


